\title{
USE OF A HETEROLOGOUS BRIDGE COATING ANTIGEN FOR THE IMMUNOASSAY \\ OF 3-ACETYLDEOXYNIVALENOL IN BARLEY
}

\author{
A Thesis \\ Submitted to the Faculty \\ of \\ Graduate Studies \\ The University of Manitoba \\ by \\ NA WANG
}

In Partial Fulfilment of the

Requirements for the Degree

of

MASTER OF SCIENCE

Department of Animal Science

May 1996 
Acquisitions and

Bibliographic Services Branch

395 Wellington Street

Ottawa, Ontario

K1A ON4
Bibliothèque nationale

du Canada

Direction des acquisitions et

des services bibliographiques

395, rue Wellington

Ottawa (Ontario)
Your file Votre référence

Our file Notre reference
The author has granted an irrevocable non-exclusive licence allowing the National Library of Canada to reproduce, Ioan, distribute or sell copies of his/her thesis by any means and in any form or format, making this thesis available to interested persons.
L'auteur a accordé une licence irrévocable et non exclusive permettant à la Bibliothèque nationale du Canada de reproduire, prêter, distribuer ou vendre des copies de sa thèse de quelque manière et sous quelque forme que ce soit pour mettre des exemplaires de cette thèse à la disposition des personnes intéressées.

L'auteur conserve la propriété du droit d'auteur qui protège sa thèse. Ni la thèse ni des extraits substantiels de celle-ci ne doivent être imprimés ou autrement reproduits sans son autorisation. 
Name

Dissertation Abstracts International and Masters Abstracts International are arranged by broad, general subject categories. Please select the one subject which most nearty describes the content of your dissertation or thesis. Enter the corresponding four-digit code in the spaces provided.

\section{Heacth \& Enwomplatal Salences}

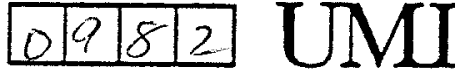

\section{Subject Categories}

\section{THE HUMANITIES AND SOCIAL SCIENCES}

\section{COMHUNICATIONS AKD THE ARTS}

Archilecture

Art History …....................................037

Ginema ........................................0900

Dance

Fine Arts ........................................0357

Information Scienco .....................0723

foumalism ..............................0391 0399

Mass Communications ........ 0708

Music ....................................0413

Sosoch Communication

Thooter .......................................0459

EDUCATION

Generol ....................................0515

Administration ..........................0514

adult and Continuing ....................0516

Agricultural ................................0517

Artingud and Multicuturo

3usinoss and Mulinelturol..........028

Jommunity Collogo ......................0275

Eurriculum and Instruction _........0727

Sarty Childhood ..........................0518

Jamentary ..............................0524

Guidanco and Counsoling ..........0519

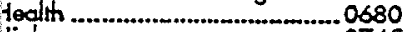

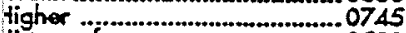

tistory of ......................................0520

tome Economio - -...0278

ndustrial ............................0521

anguage and Literature .............0279

Aathematic ...........................0280

Ausic ..................................0522

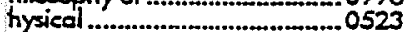

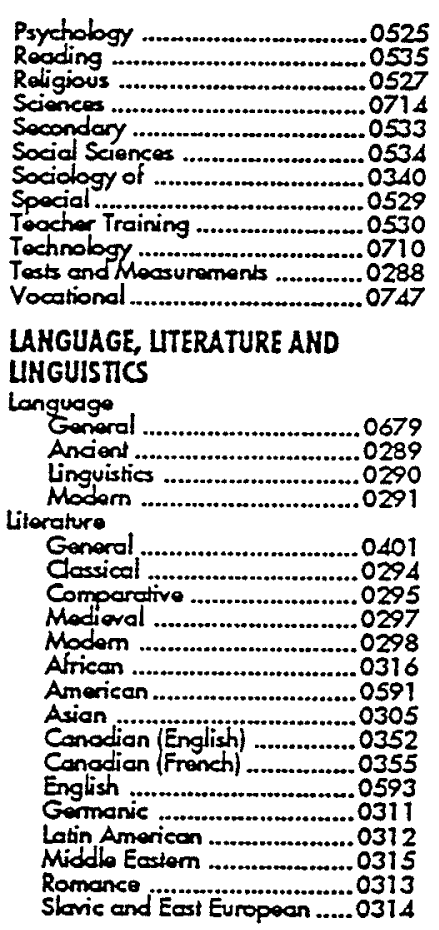

PHILOSOPHY, RELIGION AND

THEOLOGY

Philosophy ...................................0422

Religion

General ......................0318

Biblical Studies .........................032

dergy ....................................0319

History of ...........................0320

Theology .....................................0469

SOQAL SCENCES

0323

Anthropology

Archooplogy .......................032d

Culturd ........0326

Physical ...............................0327

Business Administration

General..............................0310

Acoorunting ……......................0272

Bonking .............................0775

Manogemont........................0338

Conodian Studies .........................0385

Economic

Goneral .............................0501

Agricultural ........................0503

Commerce-Businass ................0505

Finance ................................0508

Hisbry................................0509

Theory ...............................0511

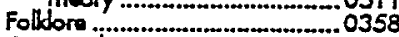

Geography...............................0366

Gerontology

Gistory

0578

SUBJECT CODE

\section{THE SCIENCES AND ENGINEERING}

\section{IOLOGICAL SAENCS}

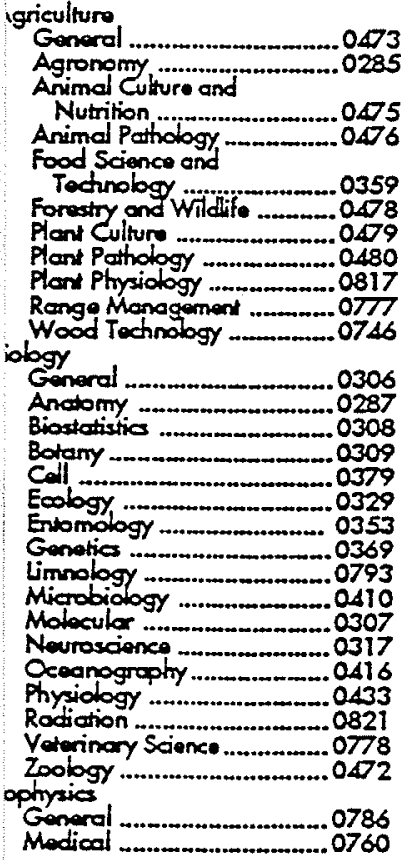

IRTH SOENEES

ogrochomistry

ochemistry

0425

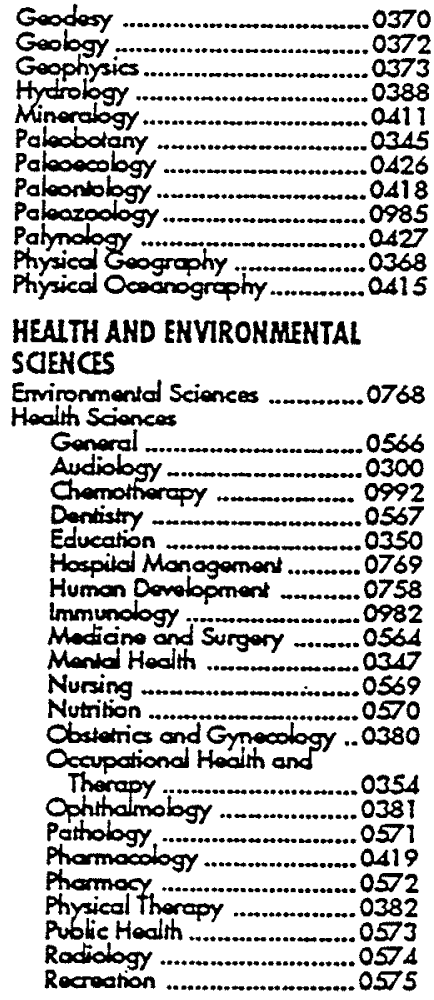

Speoch Pattology ................ 0460

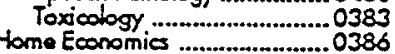

PHYSICAL SAEHCES

Pure Sciences

Chemistry

General ..............................0485

Agrioultural ............................0749

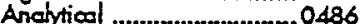

Biochemistry .................................. 0487

irorganic ............................. 0488

Nuclogr ................................ 0738

Orgonic ........................... 049

Physical ...................................0494

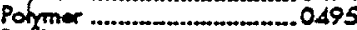

Rodition .............................. 045

Mathematic

.0754

Physic

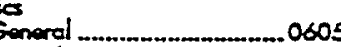

Acovitio ...........................0986

Astronomy and

Astrophysics.....................

Amospheric Science ...............0608

Abomic .............................0748

Electronic and Electricity .....0607

Eemoniary Particles and

High Enorgy ....................0798

Fivid and Plasma ....................0759

Moleculer .............................. 0609

Nudoar ...................................0610

Optic .................................. 0752

Rodiction ....................................0756

Solid State ................................... 0611

Statistios .......................................... 0463

Applied Sciences

Applied Mechanies ....................0346

Computar Scienco ..........................0984
Enginooring

Aarerace...........................0537

Agriailural ........................ 0538

Automotive ............................. 0540

Biomedical ............................... O541

Chamied ................................ 0542

Givil ............ Ejectrical .......0544

Heat and Thermodynamies....0348

Hydroulic..............................0545

industrial ............................... 0546

Marine ............................ 0547

Materials Science ..................0794

Mechonicel .............................0548

Mexallurgy ....................................0743

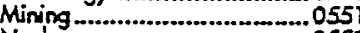

Nudoer .................................... 0552

Petroleum... 0765

Sanitary and Muricipal .........0554

System Science.......................0790

Geotectunology ............................. 0428

Oporations Research ..................0796

Prostic Technology .........................0995

\section{PSYCHOLOGY}

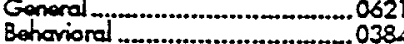

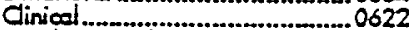

Derdopmental ............................... 0620

Experimental ................................ 0623

Industrial..

Personality

Physiological

Psychomatries ............................... 0632
Social ................................. 


\title{
THE UNIVERSITY OF MANITOBA
}

FACUTY OF GRADUATE STUDIES

\author{
COPYRIGHT PERMISSION
}

USE OF A HETEROLOGOUS BRIDGE COATING ANTIGEN

FOR THE IMMUNOASSAY OF 3-ACETYLDEOXYNIVALENOL IN BARLEY

BY

NA WANG

A Thesis/Practicum submitted to the Faculty of Graduate Studies of the University of Manitoba in partial fulfillment of the requirements for the degree of

MASTER OF SCIENCE

Na Wang O 1996

Permission has been granted to the LIBRARY OF THE UNIVERSITY OF MANITOBA to lend or sell copies of this thesis/practicum, to the NATIONAL LIBRARY OF CANADA to microfilm this thesis/practicum and to lend or sell copies of the film, and to UNIVERSITY MICROFILMS INC. to publish an abstract of this thesis/practicum..

This reproduction or copy of this thesis has been made available by authority of the copyright owner solely for the purpose of private study and research, and may only be reproduced and copied as permitted by copyright laws or with express written authorization from the copyright owner. 


\section{DEDICATION}

This thesis is dedicated to my husband, Bin, who has given me a warm home and strong shoulder to rely on and who drove me back and forth to downtown medical center for the classes in those many cold early winter mornings.

This is also dedicated to my mother, dad and sister, Xianming, Yiliang and Rong, who have always been there whenever I need it, who have given me the deepest love and care from thousands miles away and to my dad on the occasion of his 60th birthday. 


\begin{abstract}
Wang, Na. M.Sc., The Faculty of Food and Agricultural Sciences, University Of Manitoba. May, 1996. Use of a Heterologous Bridge Coating Antigen for the Immunoassay of 3-Acetyldeoxynivalenol in Barley. Supervisor: Dr. Ronald R. Marquardt.

The study describes procedures that were used to develop a highly sensitive enzyme-linked immunosorbent assay (ELISA) for the quantitation of a trichothecene mycotoxin, 3-acetyldeoxynivalenol (3-AcDON), in barley. Polyclonal antibodies were produced in rabbits immunized with a conjugate of 3-AcDON and human serum albumin linked by an ester linkage (hemisuccinate bridge). High anti-3-AcDON titers were obtained after multiple immunizations. However, only a negligible degree of inhibition was obtained with 3-AcDON in a competitive ELISA when the coating conjugate contained the same ester linkage group (hemiglutarate bridge) as the immunogen. The use of a conjugate containing a heterologous ether linkage (O-methylcarboxyl bridge) compared to that of the immunogen yielded an inhibition curve for 3-AcDON that was highly sensitive $\left(\mathrm{IC}_{50}=0.21 \mathrm{ng} / \mathrm{ml}\right)$ with essentially no interference from the bridging group. This conjugate was synthesized using iodoacetate and 1,1'-carbonyldiimidazole chemistries. The assay showed low cross-reactivity with other trichothecenes including several analogs of deoxynivalenol (DON) with the exception of acetylated DON. The ELISA developed on the basis of this new conjugate was able to detect low concentrations of 3-AcDON (16 ppb) in spiked barley without any clean-up treatment.
\end{abstract}




\section{ACKNOWLEDGEMENT}

I would like to express my foremost and sincere gratitude to my supervisor, Dr. Ronald R. Marquardt. Thanks him for accepting me as a graduate student under his guidance. Thanks him for his enthusiasm, knowledge, understanding and continuous encouraging and supporting in helping the completion of my degree. His persistence and humours towards difficulties enabled me to pass through the hard time during my study and research. Also thanks him for providing me chances to be in several international and local conference and workshops, from which I gained much experience and knowledge.

I would also like to appreciate my graduate committee members for their guidance and assistance, especially Dr. David Abramson, for his valuable advice and wonderful slides for the seminar and Dr. Andrew Frohlich, for his technical expertise and considerable help in those experiments with animals.

My special thanks are extended to Dr. Danuta Kierek-Jaszczuk, for her tremendous help and friendship from the first day I came until now. Thanks to her for the excellent and unselfish advice and support in preparing my research proposal. I had pleasure to have her as a mentor and a colleague as well as a friend. Also thanks to Ms. Suzhen Li, who had given me so many helps when I was a stranger in the lab, and whose hard-working attitude inspired me a lot.

Thanks to all the personals who were or are working in our nutritional 
toxicology group, specially Dr. Hao Xiao and Dr. James Clark for their discussion and suggestions.

My profound thanks and appreciation are to Prof. Yang-zhi Ling, my fatherin-law, in the respect to the advice in chemical synthesis. Thanks to Mrs. Helena Majgier-Baranowska in the Department of Chemistry, with all the help in preparing the computer images and drawings.

Thanks to the financial support of the strategic grant from the Natural Sciences and Engineering Research Council of Canada.

Thanks to Dr. Garry Crow, Dr. Loreen Onischuk, Dr. Sam Badoo in the Department of Animal Science for the help with preparing slides and seminars. Thanks to the secretaries, Shirley McFaren, Allison Cranmer and Margaret Ann Baker, who gave me helps in many ways.

Finally, sincere thanks to all my fellow graduate students, including those who successfully obtained their degrees and those who are still in the battle, for making me feel home away from home and for the enjoyable time spent in the department. Thanks particularly to Curt Bossuyt, Tracy Knight and Stefan Schmuelgen. 


\section{TABLE OF CONTENTS}

\section{ABSTRACT \\ DEDICATION}

ACKNOWLEDGEMENTS

TABLE OF CONTENTS $\ldots \ldots \ldots \ldots \ldots \ldots \ldots \ldots \ldots$ i

LIST OF TABLES $\ldots \ldots \ldots \ldots \ldots \ldots \ldots \ldots \ldots \ldots \ldots \ldots$ iv

LIST OF FIGURES $\ldots \ldots \ldots \ldots \ldots \ldots \ldots \ldots \ldots \ldots \ldots$

LIST OF ABBREVIATIONS $\ldots \ldots \ldots \ldots \ldots \ldots \ldots \ldots \ldots$ vii

INTRODUCTION $\ldots \ldots \ldots \ldots \ldots \ldots \ldots \ldots \ldots \ldots \ldots \ldots$

LITERATURE REVIEW $\ldots \ldots \ldots \ldots \ldots \ldots \ldots \ldots \ldots \ldots$

1. Toxigenic fungi and mycotoxin $\ldots \ldots \ldots \ldots \ldots \ldots$

1.1 Major mycotoxins and the fungi response for their

Production $\ldots \ldots \ldots \ldots \ldots \ldots \ldots \ldots \ldots \ldots \ldots \ldots \ldots$

1.2 Environmental factors involved in the growth of

Fusarium and the production of deoxynivalenol

(DON)-type toxins $\ldots \ldots \ldots \ldots \ldots \ldots \ldots \ldots$

1.3 Economic impact of mycotoxin contamination .......9

2. Natural occurrence of DON-type toxins $\ldots \ldots \ldots \ldots$

$2.1 \quad$ Worldwide contamination of DON $\ldots \ldots \ldots \ldots \ldots$

2.2 DON contamination in the US and Canada $\ldots \ldots \ldots 10$ 
3. Chemical and physical characteristics of DON, its analogs

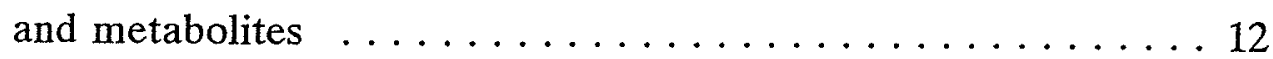

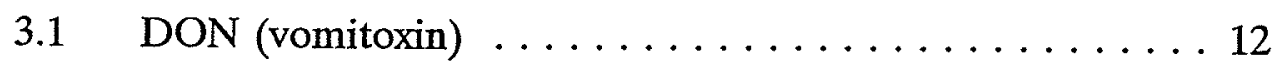

3.2 3-Acetyldeoxynivalenol (3-AcDON) and 15-acetylDeoxynivalenol (15-AcDON) $\ldots \ldots \ldots \ldots \ldots \ldots$

3.3 Transformation of DON and 3-AcDON by micro$\operatorname{organisms} \ldots \ldots \ldots \ldots \ldots \ldots \ldots \ldots$

4. Biological activities of DON and 3-AcDON $\ldots \ldots \ldots \ldots 14$

4.1 Pathogenic and toxigenic effects of DON and the Fungi responsible for its production in agricultural

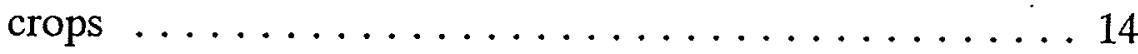

4.2 Toxic effects of DON on animal health $\ldots \ldots \ldots 17$

4.3 Toxic effects of DON and 3-AcDON on rodents ..... 19

4.4 Experimental and epidemiological investigations of the biological effects of DON and 3-AcDON

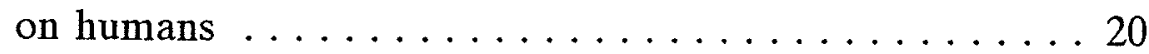

5. Prevention and detoxification of DON-type toxins $\ldots \ldots \ldots 20$

6. Standard techniques for the monitoring of DON and 3-

AcDON in agricultural products $\ldots \ldots \ldots \ldots \ldots \ldots \ldots 21$

6.1 Regulatory levels of DON in North America . . . . . . . 22

6.2 General procedures for mycotoxin analysis $\ldots \ldots \ldots 23$ 
6.3 Physicochemical approaches: TLC, HPLC, GC and MS methods for DON and 3-AcDON analysis . . . . . 24

7. Immunochemical assays for the determination of DON and $3-A c D O N$ in agricultural commodities $\ldots \ldots \ldots 27$

7.1 General principles for the development of immunoChemical assays $\ldots \ldots \ldots \ldots \ldots \ldots \ldots \ldots 27$

7.2 Types of immunochemical assays used for the determination of mycotoxins $\ldots \ldots \ldots \ldots 28$

7.3 Preparation of toxin-protein conjugates for immunization . 33

7.4 Production and characterization of specific antibodies Against DON and 3-AcDON ........... 35

7.5 Performance criteria of immunoassay for mycotoxins . . 37

7.6 Preparation of toxin-protein conjugates for use as The assay/coating antigen in ELISAs $\ldots \ldots \ldots \ldots 38$

7.7 quantitative ELISAs for 3-AcDON, DON and other DON analogs $\ldots \ldots \ldots \ldots \ldots \ldots \ldots \ldots \ldots \ldots \ldots \ldots \ldots$

MATERIALS AND METHODS $\ldots \ldots \ldots \ldots \ldots \ldots \ldots \ldots \ldots$

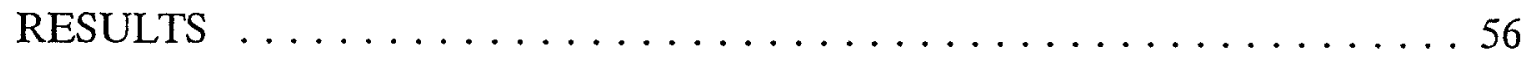

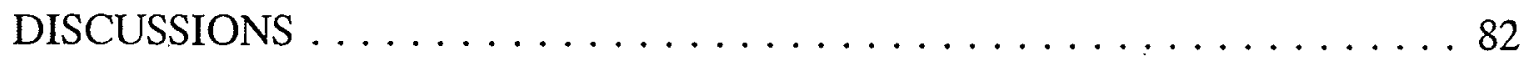

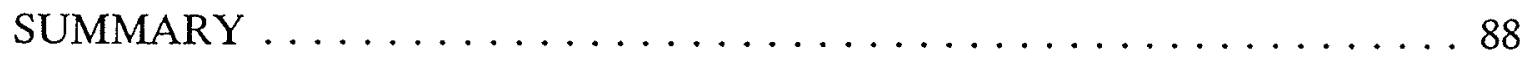

LITERATURE CITED $\ldots \ldots \ldots \ldots \ldots \ldots \ldots \ldots \ldots \ldots \ldots \ldots \ldots$ 


\section{LIST OF TABLES}

Table 1. Side Chain Residues for 3-Acetyldeoxynivalenol $(3-\mathrm{AcDON})$ and Related Trichothecenes $\ldots \ldots \ldots$

Table 2. World-wide Natural Occurrence of Deoxynivalenol $(\mathrm{DON})$ in Agricultural Commodities . . . . . . . . . . . 11

Table 3. Analysis of Deoxynivalenol (DON) in Agricultural Commodities by Physicochemical Methods:

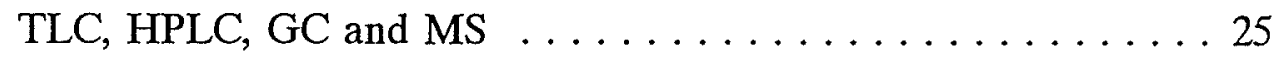

Table 4. Quantitative Immunoassays (RIA and ELISA) for Deoxynivalenol (DON) Using Rabbit Polyclonal Antibodies (PAb) or Mouse Monoclonal Antibodies (Mab) ......... . 42

Table 5. Quantitative Immunoassays (ELISAs) for 3-Acetyldeoxynivalenol (3-AcDON) and 15-Acetyldeoxynivalenol (15-AcDON) Using Rabbit Polyclonal Antibodies $(\mathrm{PAb})$ or Mouse Monoclonal Antibodies (Mab) . . . . . . . 43

Table 6. Reactivities of the Antiserum with 3-Acetyldeoxynivalenol (3-AcDON) and Other Related Trichothecenes ......... 73

Table 7. Recovery of 3-Acetyldeoxynivalenol (3-AcDON) from Spiked Barley Samples Using Acetonitrile-water (84:16) and Methanol-water $(70: 30)$ as Extraction Solvent ........ 79 


\section{LIST OF FIGURES}

Figure 1. Structures of 3-acetyldeoxynivalenol (3-AcDON) and related trichothecenes $\ldots \ldots \ldots \ldots \ldots \ldots \ldots \ldots$

Figure 2. Transformation pathways of deoxynivalenol (DON)type toxins in mycelia of Fusarium spp. . . . . . . . 15

Figure 3. Immunochemical assays for mycotoxins . . . . . . . . . 29

Figure 4. Schema for the synthesis of 3-acetyldeoxynivalenol (3-AcDON)-protein conjugates used as the

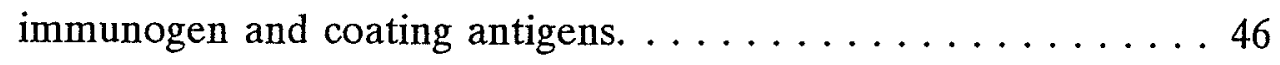

Figure 5. Typical production of polyclonal antibodies against 3-acetyldeoxynivalenol (3-AcDON) in rabbits (5a) and chickens $(5 b) \ldots \ldots \ldots \ldots \ldots \ldots \ldots \ldots \ldots \ldots \ldots \ldots \ldots \ldots \ldots$

Figure 6. The effects of plate coating antigen concentration on the performance of indirect competitive ELISA. . . . . 60

Figure 7. The effects of antibody concentration on the performance of indirect competitive ELISA $\ldots \ldots \ldots 63$

Figure 8. Effects of different coating conjugates on the sensitivity and Non-inhibitable background of the competitive ELISA using 3-acetyldeoxynivalenol (3-AcDON) as the competitor $\ldots \ldots \ldots \ldots \ldots \ldots \ldots 67$ 
Figure 9. Competition for antibody binding between free compounds

3-AcDON (-口-m-, A), 3-AcDON-HG (-А-A-, B2), 3-

AcDON-OXM (-๑-@-, B4) and immobilized conjugate:

3-AcDON-MC-OVA $(10 \mu \mathrm{g} / \mathrm{ml})$ in the indirect competitive

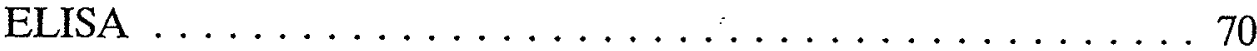

Figure 10. The effects of acetonitrile and extract from barley matrix

on the standard curve of $3-\mathrm{AcDON}$ as obtained with the indirect competitive ELISA $\ldots \ldots \ldots \ldots \ldots \ldots \ldots$

Figure 11. The effects of methanol and extract from barley matrix on the standard curve of 3-AcDON as obtained with the indirect competitive ELISA $\ldots \ldots \ldots \ldots \ldots \ldots 77$

Figure 12. Typical standard curve for the detection of 3-AcDON using the direct antigen capture ELISA $\ldots \ldots \ldots \ldots \ldots 8$

Figure 13. Three-dimensional molecular computer images of 3-AcDON used in the preparation of the immunogen and the coating antigens $\ldots \ldots \ldots \ldots \ldots \ldots \ldots$ 


\section{LIST OF ABBREVIATIONS}

\begin{tabular}{|c|c|c|}
\hline A & ........................... & absorbance \\
\hline $\mathrm{Ab}$ & …..................... & antibody \\
\hline AcDON & 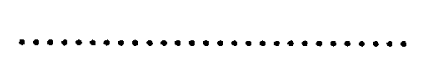 & acetylated deoxynivalenol \\
\hline 3-AcDON & 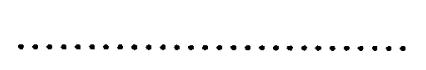 & 3-acetyldeoxynivalenol \\
\hline $15-A c D O N$ & & 15-acetyldeoxynivalenol \\
\hline AcNIV & & acetylated nivalenol \\
\hline $\mathrm{AE}$ & (n................ & active ester \\
\hline $\mathrm{Ag}$ & & antigen \\
\hline $\mathrm{AP}$ & & alkaline phosphatase \\
\hline BSA & 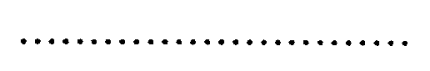 & bovine serum albumin \\
\hline $\mathrm{BW}$ & 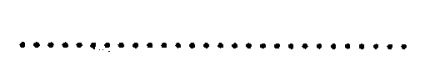 & body weight \\
\hline${ }^{\circ} \mathrm{C}$ & & degree Celsius \\
\hline CDI & & 1,1'carbonyldiimidazole \\
\hline CFA & ............ & complete Freund's adjuvant \\
\hline $\mathrm{CH}_{3} \mathrm{CN}$ & $\cdots \cdots$ & acetonitrile \\
\hline CMO & & carboxymethyloxime \\
\hline $\mathrm{DCC}$ & $\cdots \cdot$ & dicyclohexylcarbodiimide \\
\hline DEA & ............. & diethanolamine \\
\hline DON & $\ldots \ldots \ldots$ & deoxynivalenol \\
\hline $\mathrm{ECD}$ & n............ & electron capture detector \\
\hline EIA & $\ldots \ldots \ldots \ldots \ldots \ldots \ldots, \ldots, \ldots$ & enzyme immunoassay \\
\hline ELISA & $\ldots \ldots \ldots \ldots \ldots \ldots$ & enzyme-linked immunosorbent assay \\
\hline GC & $\ldots \ldots$ & gas chromatography \\
\hline $\mathrm{HCl}$ & $\ldots \ldots+\cdots, \ldots+\cdots, \ldots$ & hydro chloride \\
\hline
\end{tabular}




\begin{tabular}{|c|c|c|}
\hline HFB & ㄴ.1, & heptaflurobutyrylimidazole \\
\hline HG & & hemiglutarate \\
\hline HPLC & ......... & high performance liquid chromatography \\
\hline HPTLC & & high performance thin layer \\
\hline & & chromatography \\
\hline hr & & hour \\
\hline HRP & & horseradish peroxidase \\
\hline HS & & hemisuccinate \\
\hline HSA & & human serum albumin \\
\hline $\mathrm{IC}_{50}$ & & $50 \%$ inhibition concentration \\
\hline IFA & $\cdots$ & incomplete Freund's adjuvant \\
\hline IgG & & immunoglobulin $\mathrm{G}$ \\
\hline $\operatorname{Ig} Y$ & . & chicken immunoglobulin $\mathrm{G}$ \\
\hline $\mathrm{KCl}$ & ..... & potassium chloride \\
\hline $\mathrm{Kg}$ & & kilogram \\
\hline $\mathrm{KLH}$ & & leyhole limpet hemocyanin \\
\hline $\mathrm{LD}_{50}$ & .. & $50 \%$ lethal dosage \\
\hline M & ..... & molarity \\
\hline MA & & mixed anhydride \\
\hline MAb & (n............ & monoclonal antibody \\
\hline $\mathrm{MC}$ & ... & methylcarboxyl \\
\hline $\mathrm{MeOH}$ & & methanol \\
\hline $\mathrm{mg}$ & ............ & milligram \\
\hline $\min$ & 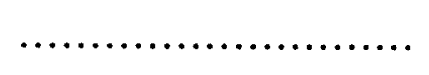 & minute \\
\hline $\mathrm{ml}$ & ...... & milliliter \\
\hline $\mathrm{mM}$ & ........ & millimolarity \\
\hline MS & (n...................... & mass spectrometry \\
\hline $\mathrm{Na}_{2} \mathrm{CO}_{3}$ & (1) & sodium carbonate \\
\hline
\end{tabular}




\begin{tabular}{|c|c|c|}
\hline $\mathrm{NaCl}$ & ……....... & sodium chloride \\
\hline ng & $\ldots$ & nanogram \\
\hline NHS & ... & N-hydroxysuccinimide \\
\hline NIV & .... & nivalenol \\
\hline $\mathrm{nm}$ & & nanometre \\
\hline NMR & & nuclear magnetic resonance spectrometry \\
\hline OPD & & o-Phenylenediamine \\
\hline OVA & & chicken egg ovalbumin \\
\hline $\mathrm{PAb}$ & & polyclonal antibody \\
\hline PBS & & phosphate buffer saline \\
\hline PBST & & phosphate buffer saline with Tween-20 \\
\hline PLL & & polylysine \\
\hline pNPP & & p-Nitrophenyl Phosphate \\
\hline $\mathrm{ppb}$ & & parts per billion \\
\hline ppm & ..... & parts per million \\
\hline RIA & ............ & radioimmunoassay \\
\hline SD & ..... & standard deviation \\
\hline TLC & .............. & thin layer chromatography \\
\hline$\mu \mathrm{g}$ & (n....................... & microgram \\
\hline$\mu \mathrm{l}$ & (.................. & microliter \\
\hline WSC & & water-soluble carbodiimide \\
\hline
\end{tabular}




\section{INTRODUCTION}

3-Acetyldeoxynivalenol ( $3 \alpha$-acetoxy-7 $\alpha, 15$-dihydroxy-12,13-epoxy-trichothec-9en-8-one; 3-AcDON) is a major secondary metabolite of field fungi such as Fusarium graminearum and Fusarium culmorum (Miller et al, 1983; Ueno, 1983; Yoshizawa and Morooka, 1973). It is one of the monoacetyl analogues of deoxynivalenol (DON, vomitoxin) which belong to a group of trichothecene mycotoxins sharing the 12,13 epoxy-trichothec-9-ene-skeleton (Figure 1 and Table 1). Trichothecenes occur most frequently in wheat, barley, rice and corn with DON type toxins being the most important in terms of incidence (Scott, 1982). The adverse effects of DON in animals include feed refusal, emesis, and ultimately reduction in weight gain (Ueno, 1983). In addition, 3-AcDON or another monoacetyl analog of DON, 15-acetyldeoxynivalenol (15AcDON), have acute and subacute toxic effects on mice (Forsell et al; Kasali et al, 1985 and Schiefer et al, 1985 ) and immunosuppressive effects on rodent and human lymphoid cells (Atkinson and Miller, 1984; Tomar et al, 1987). The widespread and high levels of contamination of grains with DON-type toxins and their potential hazardous effects on animals and humans has stimulated considerable research on the development of analytical techniques for detection of this class of toxin. Rapid progress has been made in this area during the past decade including the development of improved physicochemical methods such as TLC, GC-MS and HPLC (for review see Scott, 1982) and immunological approaches such as RIA and ELISA (Abouzied et al, 1991a; Mills 
et al, 1990 and Xu et al, 1988). In the last few years, ELISA and other ELISA based procedures have gained more acceptance as they offer the advantage of specificity, sensitivity, simplicity and rapidness which are important for routine test applications. Several ELISAs for DON detection have been developed utilizing monoclonal or polyclonal anti-DON antibodies with most of them having high cross-reactivity with 3AcDON (Abouzied et al, 1991b; Casale et al, 1988 and Usleber et al, 1991). Only a few assays have been reported for the screening of 3-AcDON (Kemp et al 1986 and Usleber et al, 1991) and other acetylated forms of DON (Sinha et al, 1995; Usleber et al, 1993 and Zhang et al 1986). Previous studies have shown that DON and 3-AcDON can be reversibly acetylated and deacetylated in fungal cultures through a microbial transformation pathway (Yoshizawa and Morroka, 1975). In some Fusarium species, the 3-acetyl form of the toxin frequently co-occurs with the parent alcohol or is even the predominant product (ApSimon et al 1990 and Miller et al, 1983). This would suggest that more attention should be directed towards 3-AcDON, especially since DON does not appear to be the sole toxic agent responsible for the adverse effects observed in intoxicated animals (Foster et al, 1986). Therefore, the objective of this study was to develop a specific and sensitive immunoassay for 3-AcDON. In the present study, several new 3-AcDON derivatives and protein conjugates were synthesized. They contained bridging lengths, structures, linkage site or protein carriers that were different from those of the immunogen. The performance of the assays was evaluated when these conjugates were used in indirect competitive ELISAs as the plate coating antigens. On the basis of the results, an assay was developed that minimized the interference of the 
bridging group and protein carrier. The assay was able to detect low concentration of 3-AcDON in spiked barley. 
Figure 1. Structures of 3-acetyldeoxynivalenol (3-AcDON) and related trichothecenes.

The side chain residues for different toxins used in the present study are listed in Table 1. 


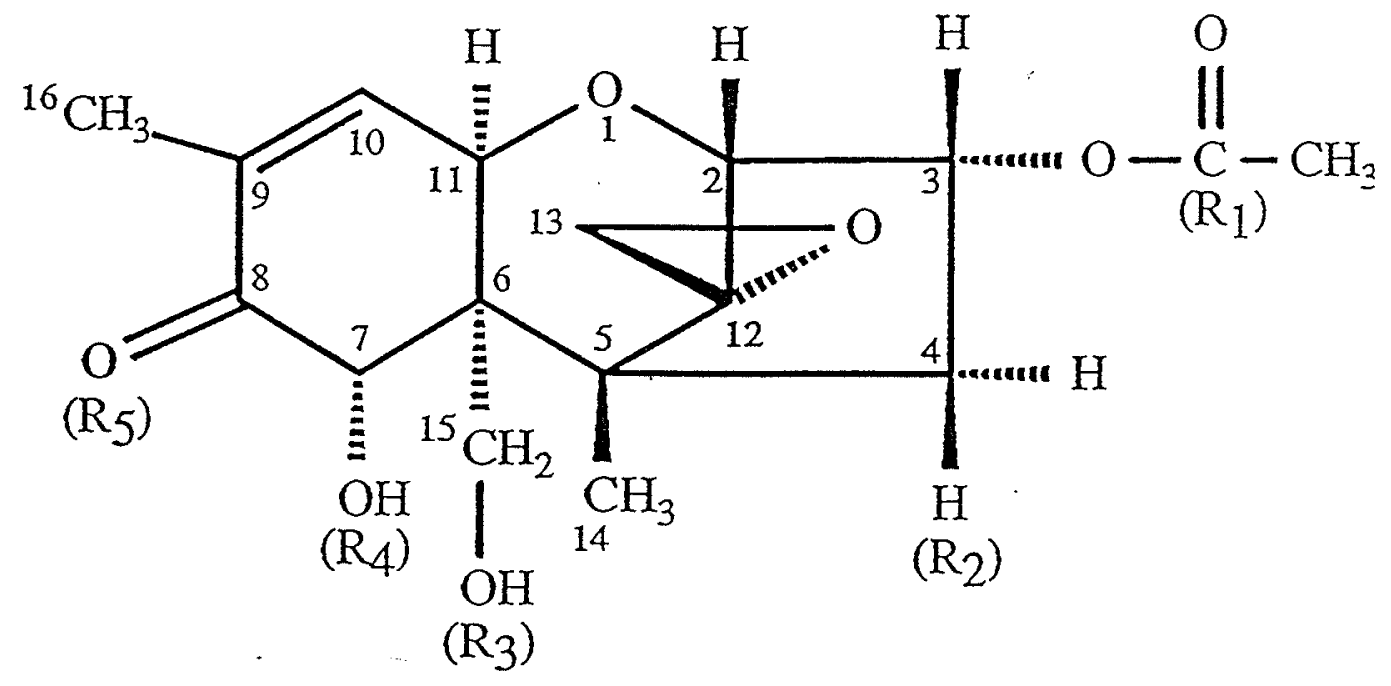


Table 1. Side Chain Residues for 3-Acetyldeoxynivalenol (3-AcDON) and Related Trichothecenes

\begin{tabular}{|c|c|c|c|c|c|c|}
\hline & \multirow[t]{2}{*}{ Toxins } & \multicolumn{5}{|c|}{ Side chain residues } \\
\hline & & $\begin{array}{c}R_{1} \\
(C-3)\end{array}$ & $\begin{array}{c}\mathbf{R}_{2} \\
(\mathrm{C}-4)\end{array}$ & $\begin{array}{c}\mathbf{R}_{3} \\
(\mathrm{C}-15)\end{array}$ & $\begin{array}{c}R_{4} \\
(C-7)\end{array}$ & $\begin{array}{c}\mathrm{R}_{5} \\
(\mathrm{C}-8)\end{array}$ \\
\hline \multirow{8}{*}{$\underset{\text { B }}{\text { Group }}$} & Deoxynivalenol & $\mathbf{O H}$ & $\mathbf{H}$ & $\mathrm{OH}$ & $\mathrm{OH}$ & $=0$ \\
\hline & $\begin{array}{l}\text { 3-Acetyl } \\
\text { deoxynivalenol }\end{array}$ & $O A c^{b}$ & $\mathbf{H}$ & $\mathrm{OH}$ & $\mathrm{OH}$ & $=0$ \\
\hline & $\begin{array}{l}\text { 15-Acetyl } \\
\text { deoxynivalenol }\end{array}$ & $\mathrm{OH}$ & $\mathbf{H}$ & OAc & $\mathrm{OH}$ & $=0$ \\
\hline & $\begin{array}{l}\text { Tri-acetyl } \\
\text { deoxynivalenol }\end{array}$ & OAc & $\mathbf{H}$ & OAc & OAc & $=0$ \\
\hline & Nivalenol & $\mathrm{OH}$ & $\mathrm{OH}$ & $\mathrm{OH}$ & $\mathrm{OH}$ & $=0$ \\
\hline & Acetyl nivalenol & OAc & OAc & OAc & OAc & $=0$ \\
\hline & Fusarenon X & $\mathrm{OH}$ & OAc & $\mathrm{OH}$ & $\mathrm{OH}$ & $=0$ \\
\hline & Trichothecolone & $\mathbf{H}$ & $\mathrm{OH}$ & $\mathrm{H}$ & $\mathrm{H}$ & $=0$ \\
\hline \multirow{6}{*}{$\begin{array}{c}\text { Group } \\
\text { A }\end{array}$} & Diacetoxyscirpenol & $\mathrm{OH}$ & OAc & OAc & $\mathrm{H}$ & $\mathbf{H}$ \\
\hline & Neosolaniol & $\mathrm{OH}$ & OAc & OAC & $\mathbf{H}$ & $\mathrm{OH}$ \\
\hline & $\mathrm{T}-2$ & $\mathrm{OH}$ & OAc & OAc & $\mathbf{H}$ & $\mathrm{OIsv}^{b}$ \\
\hline & HT-2 & $\mathrm{OH}$ & $\mathrm{OH}$ & OAc & $\mathrm{H}$ & OIsv \\
\hline & Acetyl T-2 & OAc & OAc & OAc & $\mathbf{H}$ & OIsv \\
\hline & $\begin{array}{l}\text { T-2 tetraol } \\
\text { tetraacetate }\end{array}$ & OAc & OAc & OAc & OAc & OAc \\
\hline
\end{tabular}

- See structures of 3-acetyldeoxynivalenol and related trichothecenes in Figure 1.

${ }^{b}$ Abbreviations: OAc, O-CO- $\mathrm{CH}_{3}$; OIsv, O-CO- $\mathrm{CH}_{2}-\mathrm{CH}\left(-\mathrm{CH}_{3}\right)_{2}$ 


\section{LITERATURE REVIEW}

\section{Toxigenic fungi and mycotoxins}

The pathogenic nature of certain species of fungi to plants has been observed since the beginning of agriculture (ApSimon et al., 1990). These fungi often produce secondary metabolites referred to as mycotoxins. They can have adverse effects on humans and animals when they are consumed (CAST, 1989).

\subsection{Major mycotoxins and the fungi responsible for their production}

Among hundreds of identified fungal metabolites, there are six major mycotoxins that are of greatest concern and have promoted extensive research in North America: aflatoxins, deoxynivalenol (DON), ochratoxins, ergot (Diekman and Green, 1992) and recently, the fumonisins (Scott, 1993). Aflatoxins are mainly produced by A. flavus and A. parasitius and can cause liver damage and suppression of immunity in animals. Several species of Penicillium and Aspergillus produce ochratoxin, a mycotoxin that can cause necrosis of kidney tissue. Ergot alkaloids produced by Claviceps purpurea on wheat can cause numerous problems in animals including reproductive disturbance in swine (CAST, 1989). DON and its acetyl analogs 3- or 15- aectyldeoxynivalenol (3AcDON or $15-\operatorname{AcDON}$ ), belong to the trichothecenes. They are a family of secondary metabolites that share a common structural skeleton and are produced by several genera of fungi, most notably the Fusarium species. DON was first isolated from moldy barley in Japan in 1972 and characterized in 1973 (Yoshizawa and Morooka, 1973). It was 
subsequently found to be identical to the emetic factor from corn in the USA (Vesonder et al, 1973). DON is mainly produced by $F$. graminearum and $F$. culmorum. Isolates of these fungi can also produce other closely related trichothecenes, including 3-AcDON and 15-AcDON (ApSimon et al, 1990).

\subsection{Environmental factors involved in the growth of Fusaria and the production of deoxynivalenol (DON)-type toxins}

The amount and type of toxins produced by fungi is greatly influenced by environmental factors including intrinsic factors such as fungal species and strain specificity and extrinsic factors (Moss, 1991). Three extrinsic factors (temperature, water activity and $\mathrm{pH}$ ) and their interactions are primary factors influencing toxin production. Fusarium fungi are usually associated with cold and temperate climates. However, the in vitro production of DON by $F$. graminearium was shown to increase with the increasing temperature and at $28^{\circ} \mathrm{C}$ was more than twice that produced at 25 ${ }^{\circ} \mathrm{C}$ (Young et al, 1980). Most species of Fusarium grow best at water activity values from 0.98 to 0.995 and grow very slowly, if at all, at a water activity value of 0.9 or less. The optimum $\mathrm{pH}$ range for the biosynthesis of DON by $F$. graminearum has been shown to be 5.2 to 6.5 (Greenhalgh et al, 1983). Environmental stress, such as water stress and high temperatures, along with insect damage of the host plant are the major stimulations for fungi infestation and toxin production. In addition, the stages of crop growth, availability of nutrients, crop density and storage condition after harvest have also been associated with mold growth and the formation of toxins (Moss, 1991). 


\subsection{Economic impact of mycotoxin contamination}

Mycotoxins can cause a wide range of adverse economic effects, mostly as losses that occur at various stages of crop production. They may also occur during the processing, transportation and storage. The consumption of fungal infected and mycotoxin contaminated feeds by animals decrease productivity and therefore result in economic losses for livestock and poultry producers. When this contamination enters the higher food chain, it can also be a health hazard to humans. It has been calculated that the cumulative annual costs of mycotoxins in Canada alone is in the order of $\$ 500$ million, including the loss in grain and animal production, multiplier effects on other industries, human illness, medical treatment and the cost for the research and analysis (ApSimon et al, 1990). Still the losses to the consumers and the social aspects are not easily quantified. Therefore, the ultimate objectives of the research on the occurrence, chemical properties, biological action, analysis and the control of the mycotoxins are to provide a safe food supply to humans and animals.

\section{Natural occurrence of DON-type toxins}

Since it was discovered, the contamination of DON in food and agricultural commodities has been a world-wide problem. DON is the most important trichothecene in terms of incidence of occurrence in raw agricultural products in both the US and Canada. It is found in products such as wheat, barley corn and in processed food including flour, bread, breakfast cereal, bran, beer, snack foods and pet foods. In 
addition, products such as eggs, dairy product and meat might also be contaminated through the ingestion of toxin contaminated feeds (Scott, 1990).

\subsection{Worldwide contamination of DON}

DON and nivalenol after the aflatoxins are the mycotoxins that are most often reported to occur worldwide in raw agricultural crops. A survey from 19 countries and districts in the world is summarized in Table 2. In Asia, Europe and North and South America about $40-50 \%$ of the 500 samples that were collected were positive for DON with the average content being $292 \mathrm{ng} / \mathrm{g}$ (ppb, Tanaka et al, 1988).

\subsection{DON contamination in the US and Canada}

In North America, the number of reports on the natural occurrence of DON toxins in foods and feeds has increased markedly in the past 10 years. Extensive surveys indicated that DON contamination occurs primarily in cereal grains and is more prevalent in the northern regions than in the south. In the USA, DON is commonly found in corn and feedstuffs in the northern-central states such as Michigan, Ohio, Indiana, etc. In 1991, the FDA and the USDA federal grain inspection service reported that DON was detected in $97.1 \%$ of 207 winter wheat samples and in $58.2 \%$ of 206 spring wheat samples with the content of toxin ranging from 4 to $40 \mu \mathrm{g} / \mathrm{g}$ (Price et al, 1993). The Food Research Division, Health Protection Branch of Health and Welfare Canada reported that 44 out 45 samples of Ontario white winter wheat from the 1980 harvest contained DON at a concentration ranging from 0.01 to $4.3 \mu \mathrm{g} / \mathrm{g}$. In Quebec, $100 \%$ of the 27 samples from the red spring wheat crop were contaminated with DON with $85 \%$ having a concentration of greater than $0.3 \mu \mathrm{g} / \mathrm{g}$. Fortunately, western Canadian wheat 
Table 2. World-wide Natural Occurrence of Deoxynivalenol (DON) in Agricultural Commodities

\begin{tabular}{lllll}
\hline $\begin{array}{c}\text { Country } \\
\text { and district }\end{array}$ & Crop year & Sample & $\begin{array}{l}\text { Positive sample } \\
\text { /sample analyzed }\end{array}$ & $\begin{array}{c}\text { Average DON } \\
\text { level } \\
\text { (ppb, ng/g) }\end{array}$ \\
\hline \hline Argentina & 1983 & barley & $18 / 20$ & 237 \\
Austria & 1984 & worn & $77 / 78$ & 790 \\
Bulgaria & 1983 & wheat & $1 / 2$ & 211 \\
Canada & $1980-84$ & wheat & $9 / 10$ & 1257 \\
China, Tawine & 1984 & wheat & $9 / 12$ & 562 \\
China, P.R. & 1985 & wheat & $7 / 7$ & 129 \\
& 1984 & wheat & $4 / 4$ & 4284 \\
England & 1984 & wheat & $20 / 31$ & 31 \\
Finland & $1985-87$ & feeds/grain & $350 / 363$ & 160 \\
France & 1984 & wheat & $1 / 2$ & 86 \\
W. Germany & 1984 & rye & $4 / 22$ & 406 \\
Greece & 1984 & wheat & $1 / 1$ & 9 \\
Hungary & 1984 & wheat & $2 / 2$ & 671 \\
Italy & 1984 & corn & $2 / 3$ & 402 \\
Japan & 1983 & barley & $5 / 5$ & 249 \\
Korea & 1984 & barley & $31 / 31$ & 124 \\
Poland & 1984 & barley & $1 / 6$ & 390 \\
Scotland & 1984 & barley & $5 / 8$ & 42 \\
Sweden & 1984 & wheat & $31 / 43$ & 240 \\
USSR & 1934 & oat & $1 / 1$ & 31 \\
\hline \hline
\end{tabular}

Adapted from Tanaka et al, 1988 and Scott, 1990. 
in the 1980 crop year from Alberta, Saskatchewan and Manitoba were not a problem as none of the 25 analysed samples contained over $0.08 \mu \mathrm{g} / \mathrm{g}$ of DON (Ueno, 1983). However, in recent years, DON contamination in agricultural products has become a more serious problem in central Canada, especially in Manitoba, due to the cool and wet growing and harvesting seasons. Clear and Abramson (1986) reported a fairly high level of DON, (9.6-14.8 $\mu \mathrm{g} / \mathrm{g})$ in Manitoba wheat of 1984 crop year.

\section{Chemical and physical characteristics of DON, its analogs and metabolites}

DON and its acetyl analogues all belong to the trichothecenes mycotoxin, which are a class of secondary metabolites isolated mainly from Fusarium fungi and are structurally closely related. The term trichothecene is derived from the name of its skeletal structure, "trichothecene" which was named by Godtfredsen et al (1967). The tichothecenes possess a basic tetracyclic, sesquiterpenoid structure which includes a sixmember oxygen-containing ring, an epoxide in the $\mathrm{C}-12,13$ position, and a double bond in the $\mathrm{C}-9,10$ position (Betina, 1989). On the basis of these structures, the trichothecenes can be classified into four groups according to their chemical properties and the fungi that produce them (Ueno, 1984). Type A trichothecenes are represented by T-2 toxin and diacetoxyscirpenol, which have an oxygen function group instead of a ketone group at the $\mathrm{C}-8$ position. DON, its acetate analogs and nivalenol represent the type $\mathrm{B}$ trichothecenes. They have a ketone group at the C-8 position (Table 1, Figure 1).

\subsection{DON (vomitoxin)}


DON ( $3 \alpha, 7 \alpha, 15$-trihydroxy-12,13-epoxy-trichothec-9-en-8-one) is a major secondary metabolite produced by field and storage Fusaria, including $F$. culmorum, $F$. roseum, $F$. graminearum and $F$. sporotrichioides. It is a fairly small molecule with a molecular weight of 296 daltons and a molecular formula of $\mathrm{C}_{15} \mathrm{H}_{20} \mathrm{O}_{6}$. DON crystallizes as fine needles. It has a melting point of $151-153{ }^{\circ} \mathrm{C}$ and is highly soluble in polar organic solvent such as methanol and acetonitrile. It has a weak UV maximum adsorption at $219 \mathrm{~nm}(\epsilon=6000)$ (Bennett et al, 1990). It has also been called vomitoxin as it induce vomiting in swines.

\subsection{3-Acetyldeoxynivalenol (3-AcDON) and 15-Acetyldeoxynivalenol (15-AcDON)}

3-AcDON (3 $\alpha$-acetoxy-7 $\alpha, 15 \alpha$-dihydroxy-12,13-epoxy-trichothec-9-en-8-one) and its isomer, 15 -AcDON (15 $\alpha$-acetoxy-3 $\alpha, 7 \alpha$-dihydroxy-12,13-epoxy-trichothec-9-en-8-one) are monoacetyl analogs of DON. Their structural formula are $\mathrm{C}_{17} \mathrm{H}_{22} \mathrm{O}_{7}$. 3-AcDON is mainly produced by $F$. culmorum and $F$. graminearum. It also crystallizes in the form of needles. It has a molecular weight of 338 daltons and a melting point of $135-136{ }^{\circ} \mathrm{C}$.

\subsection{Transformation of DON and 3-AcDON by microorganisms.}

DON and its mono-acetate, 3-AcDON, co-occur in some species of Fusaria. Yoshizawa and Morooka (1975) reported that the alcohol form of the toxin was converted from the acetyl form by microbiological deacetylation and accumulated in the mycelium of $F$. roseum during the linear growth phase. In the procession, 3-AcDON was hydrolyzed to DON by an intracellular esterase present in the growing mycelia. Studies also indicated that $F$. nivale produced 3-AcDON by the acetylation of the substrate DON. This endogenic acetylation might have progressed more efficiently if a coenzyme, such 
as acetyl coenzyme A had been added to the medium. These observations led to the suggestion that part of the DON found in the field crops may have been derived from 3AcDON. The biological and non-biological pathways for the acetylation of DON and the deacetylation of 3-AcDON during the growth and storage stage of crops are illustrated (Figure 2).

\section{Biological activities of DON and 3-AcDON}

DON and 3- or 15-AcDON have been implicated as causative agents of some adverse health effects in animals and humans. Various studies on the biological effects of DON-type toxins on the ecological system have been conducted to gain a better understanding of its toxic nature and to provide more effective protection for humans.

\subsection{Pathogenic and toxigenic effects of DON and the fungi responsible for its} production in agricultural crops

Several species of toxin producing Fusarium, such as $F$. graminearum, $F$. culmorum and $F$. sporotrichioides are important pathogens in cereal crops (Booth, 1971). They cause ear rot of preharvest corn, head blight and root rot of wheat (ApSimon et al, 1990). The pathogenesis produces shrivelled kernels and reduces the yield and value of the crop. DON and 3-AcDON are produced following the growth of fungi in the plants and are the most notorious Fusarium mycotoxins found in infected wheat, corn and barley. In eastern Canada, DON-type toxins seem to be the dominant trichothecenes in wheat infected with head blight (Teich et al, 1985). They are potent phytotoxin and 
Figure 2. Transformation pathways of deoxynivalenol (DON)-type toxins in mycelia of Fusarium spp.

microbial transformation ___ , chemical transformation -----.----.

I. deoxynivalenol (DON); II. 3-acetyldeoxynivalenol (3AcDON); III. 7acetyldeoxynivalenol (15-AcDON); IV. 7,15 diacetyldeoxynivalenol (DiAcDON); V. 3,7,15 triacetyldeoxynivalenol (TriAcDON). (Adapted from Yoshizawa et al, 1975). 


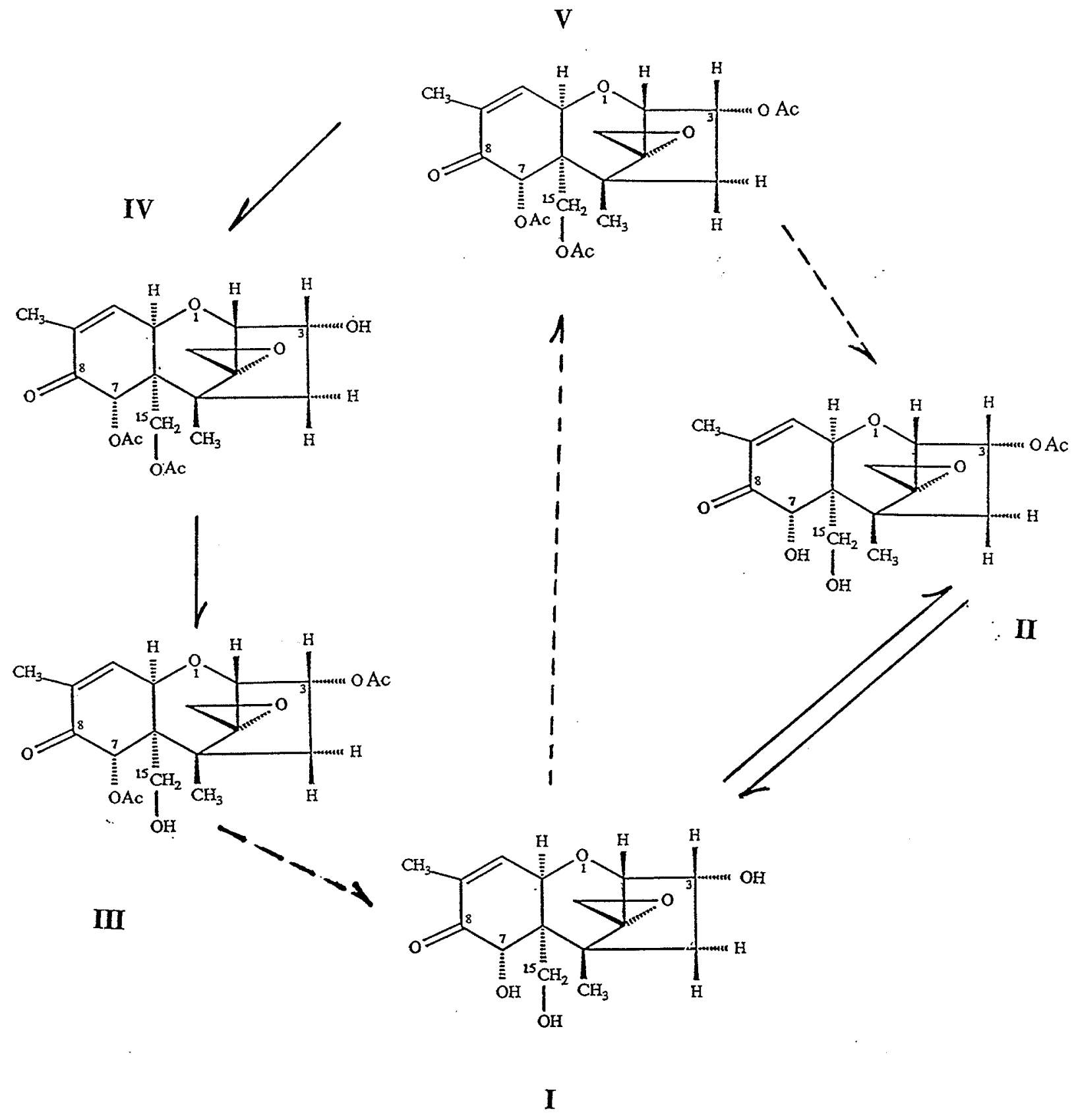


inhibitors of protein synthesis in eukaryotes. They are also regarded as aggressiveness factors in plant pathogenesis as there is a correlation between virulence of the plant disease and the production of toxins (Desjardins et al, 1989). Further concerns with the toxigenic Fusaria and the DON toxins present in agricultural crops are that they not only cause a severe reduction in crop yield, but also induce animal intoxication when contaminated grains are consumed.

\subsection{Toxic effects of DON on animal health}

Mycotoxicosis is a serious agricultural problem which can inflict considerable economic losses on the livestock and poultry industries. There is a variety of clinical symptoms in mammalian animals caused by DON and 3-AcDON. Feeding trials demonstrated that swine among three species of farm animals (swine, poultry and cattle) are most susceptible to the toxic effect of DON in contaminated feed (Trenholm et al, 1984). Typical responses of pigs fed DON-contaminated diets at concentration lower than $2 \mu \mathrm{g} / \mathrm{g}$ include emesis and reductions in feed intake and body weight gain. Results showed that there was negative liner relationship between feed intake or body weight gain and the concentration of dietary DON. It was also found that the gastric mucosa of pigs fed DON-contaminated diets was thicker and had a higher degree of folding in the esophageal region than that of the control groups. DON in naturally contaminated wheat was found to have a greater adverse effect on feed intake and body weight gain in pigs than the same concentration of pure DON (Trenholm et al, 1994). This observation is consistent with the results of another study (Foster et al, 1986). Data in this study showed that there was no signs of mycotoxications when pigs were fed $4.7 \mu \mathrm{g} / \mathrm{g}$ of pure 
DON, while all groups of pigs that received inoculated or naturally contaminated sources of the toxin had evidence of feed intake refusal and decreased body weight gains. It was concluded that the adverse effects of the contaminated diet on swine could not be explained solely by the concentration of DON in diet. It is possible that the presence of other fungal metabolites including other DON analogues in the naturally contaminated grains were responsible for the enhanced adverse effects on animals .

Compared to pigs, dairy cattle are less sensitive to the effect of dietary DON. Except for a slight decrease in feed intake, there were no apparent clinical signs of illness or weight gain reduction observed when a wheat-oats diet containing $6 \mu \mathrm{g} / \mathrm{g}$ of toxin was fed (Trenholm et al, 1985). No other report has shown any changes in milk fat and milk production when cattle were exposed to the DON contaminated diets (Noller et al, 1979). Study on lambs also indicated that lambs can tolerate moderately high intake of DON contaminated diets without clinical manifestations of toxicosis (Harvey et al, 1986). It seems that ruminal metabolism offers some protection against Fusarium trichothecenes and, as a result, ruminants are more tolerant to moderately high intake of DON than pigs.

Studies also provided evidence that DON itself had a minor effect on broiler chickens and laying hens. Poultry can tolerate at least $5 \mu \mathrm{g} / \mathrm{g}$ of DON in the feed. However, when a higher level of DON was incorporated into the diet, neural disturbance behaviour and extensive and intensive hemorrhaging occurred (Huff et al, 1981). The $\mathrm{LD}_{50}$ value was estimated to be near $140 \mu \mathrm{g} / \mathrm{g}$ (Trenholm et al, 1984 and Huff et al, 1981). In addition, egg shell weight and shell thickness of laying hens significantly 
decreased in the linear fashion as the content of DON in the diet was increased from 0 to $5.2 \mu \mathrm{g} / \mathrm{g}$ (Trenholm et al, 1984). Radio labelling studies suggested that DON or its metabolites could be transferred into the eggs of laying hens, but at a level of less than $0.2 \%$ of the amount that was fed. This would theoretically represent little, if any, threat to humans (Prelusky et al, 1987).

\subsection{Toxic effects of DON and 3-AcDON on rodents}

Rodents, as model animals, have been extensively used to study the toxicity of DON, 3-AcDON and 15-AcDON. Comparative acute toxicities studies of these toxins in mice demonstrated that the respective $\mathrm{LD}_{50}$ values for DON, 3-AcDON and 15AcDON were 78,49 and $34 \mathrm{mg} / \mathrm{kg}$ body weight (BW) when they were administered orally, and were 49,34 and $113 \mathrm{mg} / \mathrm{kg}$ BW when they were administered intraperitoneally (Forsell, 1987 and Yoshizawa and Morooka, 1971). Acute toxicities obtained by the oral administration of $100 \mathrm{mg} / \mathrm{kg} \mathrm{BW}$ of DON to mice produced extensive necrosis of the gastro-intestinal tract and bone marrow, and focal lesions on thymus and spleen tissues (Forsell et al, 1987). 3-AcDON also caused a dose-related depression in feed consumption and body weight gain when fed at concentration of 10 $\mu \mathrm{g} / \mathrm{g}$ (Kasali et al, 1985). It is evident, on the basis of acute toxicity studies and the $\mathrm{LD}_{50}$ index of 3-AcDON, DON and T-2 toxin $\left(\mathrm{LD}_{50}=5.2 \mathrm{mg} / \mathrm{kg} \mathrm{BW}\right)$ in mice, that 3AcDON and particularly T-2 are more toxic than DON. Nevertheless all these toxins affected the diving cells of the body in a manner characteristic for the trichothecenes (Schiefer et al, 1985). Both DON and 3-AcDON exhibited a dose-dependent suppression of rat lymphocyte proliferation, while DON showed a stronger cytotoxic effect than 3- 
AcDON (Atkinson and Miller, 1984). In addition, 3-AcDON inhibited the proliferation of mice lymphocytes in vitro (Tomar et al, 1987).

\subsection{Experimental and epidemiological investigations of the biological effects of DON and 3-DON on humans}

Human may be exposed to the trichothecenes including DON and 3-AcDON by the consumption of contaminated food, particularly wheat, corn, rice and their products. A survey done in the middle of China in 1990 demonstrated that there was a correlation between the degree that corn and wheat were contaminated with DON and the incidence of esophageal cancer. The investigators suggested that the toxin may be involved in esophageal carcinogenesis and potentially is an in vivo tumor-promoter (Luo et al, 1990). In vitro exposure of human blood peripheral lymphocytes to 3-AcDON and DON have been shown to reduce lymphocyte proliferation. These observations suggest that immunosuppression may occur as a consequence of exposure to these toxins, and as a result, resistance to infection may be reduced (Atkinson and Miller, 1984).

\section{Prevention and detoxification of DON-type toxins}

DON-type toxins are among the most frequent trichothecene contaminations found on cereal crops in North America. They may enter the food supply by direct contamination of foods or indirectly through the use of contaminated ingredients in the processed foods (West and Bullerman, 1991). The increasing number of reports on the presence of these toxins in foods and feeds increase the demand for practical, safe and 
effective prevention and detoxification procedures. Generally, there are two approaches for reducing the extent and amount of toxin or fungal contamination: i) preventing fungal growth or inhibiting mycotoxin formation and ii) detoxification of the contaminated products during processing. Strategies for the second approach include physical remove, chemical destruction or biological modification of the toxin.

When the degree of toxin contamination is modest, one simple way of limiting toxic problems is to dilute the contaminated grains with toxin-free grains to lower the toxin concentration below the threshold of significant biological activity. Other physical removal methods such as baking, milling and sieving can reduce the toxin content to a limited degree (Trenholm, et al 1991). Chemical detoxification methods usually involve the treatment of the contaminated grain with chemical solutions such as hydrogen peroxide, ammonium hydroxide, sodium bisulphate or sodium carbonate (Trenholm et al, 1992). Nevertheless, neither physical nor chemical methods are practical or economically feasible as it is not possible to remove the toxins without the loss of large amounts of grains or their nutrient and flavours (Smith, 1990). Biological solutions such as the breeding of plant hybrids that are resistant to the invasion of pathogenic fungi (Snijders, 1994) or the application of in vivo therapeutical treatments using anti-toxin antibodies are receiving more attention and may offer better treatment alternatives (Smith, 1990).

\section{Standard techniques for the monitoring of DON and 3-AcDON in agricultural}




\section{products}

DON and 3-AcDON have received a considerable amount of attention worldwide due to their widespread and high levels of occurrence and relative stability during food processing. These toxins in spite of their relatively low toxicity compared to other trichothecenes are deemed to present a potential hazard to animal and human health and as a result can have a very large economic impact. Theoretically, the most effective way to control mycotoxin contamination is to prevent the formation of the toxin, however, technology does not yet exist for the avoidance of toxin production or for its detoxification in foods and feeds. Thus, the control of the mycotoxin problem relies on a rigorous monitoring programs to detect the presence of toxins by effective, sensitive and reliable analytical methods so as to prevent the consumption of the contaminated food by humans and animals (Chu, 1991b).

\subsection{Regulatory levels of DON in North America}

The guideline levels established by Health and Welfare Canada with respect to DON in uncleaned soft wheat used for non-staple foods is $2.0 \mu \mathrm{g} / \mathrm{g}$ except for wheat destined for infant foods where the level is $1.0 \mu \mathrm{g} / \mathrm{g}$. The guideline levels for DON for imported non-staple foods is $1.2 \mu \mathrm{g} / \mathrm{g}$ calculated on a flour or bran basis (Scott, 1990). In the US, the current FDA advisory level for DON in wheat and milled products is 1.0 $\mu \mathrm{g} / \mathrm{g}$ for human consumption and $10 \mu \mathrm{g} / \mathrm{g}$ for grain and grain by-products for ruminants and poultry with the added recommendation that their concentration not exceed $50 \%$ of the dietary ingredient. In swine the concentration of DON in the diet should not exceed $5 \mu \mathrm{g} / \mathrm{g}$ and not more than $20 \%$ of this grain should be incorporated into the diet 
(Trucksess et al, 1994).

\subsection{General procedures for mycotoxin analysis}

Mycotoxins including DON-type toxins, are usually found in agricultural commodities in trace amount at concentrations ranging from microgram $(\mu \mathrm{g})$ to nanogram (ng) per gram (g); i.e., from $\mathrm{ppm}$ to $\mathrm{ppb}$. Their detection, therefore, requires trace analytical techniques. It is also necessary to use correct sampling and sample preparation procedures to obtain sound analytical results. Generally, mycotoxin analysis is a multistage process including the following steps: i) extraction, ii) filtration, iii) cleanup, iv) concentration, v) quantification and vi) confirmation (Steyn et al, 1991). DON and its analogues are readily soluble in many organic solvents. Extraction of the toxin is often enhanced by addition of water, especially in the case of cereals. Aqueous methanol, chloroform and acetonitrile are the most commonly used solvent for the extraction of DON-type toxins. One commercial kit for DON uses only water for its extraction (Putnam and Binkerd, 1992). After extraction, centrifugation or filtration step is necessary to remove unwanted solid. An extensive cleanup treatment depending on the analytical method may be required to remove interfering substance from the matrix. Two major approaches are used for DON quantification: 1) physicochemical methods, including thin-layer chromatography (TLC), high-performance liquid chromatography (HPLC), gas chromatography (GC) and mass-spectroscopy (MS) and 2) bioassays, which can also be divided into two sections. The first type of methodology investigates the effects of toxins on biological systems such as bacteria, fungi, microorganisms, plants, animals and in vitro on cell, tissue and organ cultures. These types of assays are 
generally semiquantitative and none-specific. The second type of bioassays, is the immunoassays (Candlish, 1991).

\subsection{Physicochemical approaches: TLC, HPLC, GC and MS methods for DON and 3-AcDON analysis (Table 3)}

TLC method has been frequently used for the detection of mycotoxin, including $\mathrm{DON}$ and other trichothecenes. It identifies toxins by comparing their $\mathrm{Rf}$ values after they are separated on a plate coated with silica gel. Visualization of DON-type toxins, which are not fluorescent, requires the spraying of chromogenic reagents on the developed plate. Reagents such as aluminium chloride, p-anisaldehyde, 4-(p-nitrobenzyl) pyridine and chromotropic acid are normally used (Baxter et al, 1983). Recently, highperformance TLC (HPTLC) has been widely used as it more efficiently separates and quantitates these compounds. The quantitation of toxins by HPTLC often involves a flurodensitrometric measurement which is highly sensitive. The detection limit using this method is reported to be $50 \mathrm{ng} / \mathrm{g}$ in barley, corn and wheat (Trucksess et al, 1987). TLC, which is widely used as a screening test, has the advantage of being simple and rapid and can be used to monitor several toxins simultaneously. However, there are also reports that naturally occurring extraneous materials in the sample matrix may interfere with the development of color by the chromogen reagents or the migration rates of the toxin on the silica plate. These factors decrease the accuracy and sensitivity of the analysis (Baxter et al, 1983).

HPLC is rapidly replacing TLC as the most popular chromatographic technique for the quantitative determination of mycotoxins (Steyn et al, 1991). Advances in the 
Table 3. Analysis of Deoxynivalenol (DON) in Agricultural Commodities by Physicochemical Methods: TLC, HPLC, GC and MS.

\begin{tabular}{|c|c|c|c|c|c|}
\hline Sample analyzed & Extraction slovent & Cleanup treatment & Analytical technique & $\begin{array}{l}\text { Detection } \\
\text { limits } \\
\text { (ng/g) } \\
\end{array}$ & Reference \\
\hline corn & $\begin{array}{c}\mathrm{CH}_{3} \mathrm{CN}-\mathrm{H}_{2} \mathrm{O} \\
(84: 16)\end{array}$ & $\begin{array}{l}\text { alumina-charcoal-Celite } \\
\text { column }\end{array}$ & TLC & 100 & $\begin{array}{l}\text { Trucksess } \\
\text { et al, } 1984\end{array}$ \\
\hline $\begin{array}{l}\text { com, } \\
\text { wheat, } \\
\text { barley }\end{array}$ & $\begin{array}{c}\mathrm{CH}_{3} \mathrm{CN}-\mathrm{H}_{2} \mathrm{O}-\mathrm{MeOH} \\
(70: 25: 5)\end{array}$ & $\begin{array}{c}\text { lead acetate precipitation, } \\
\text { alumina-charcoal-Celite } \\
\text { column }\end{array}$ & HPTLC & 50 & $\begin{array}{l}\text { Trucksess } \\
\text { et al, } 1987\end{array}$ \\
\hline maize & $\mathrm{MeOH}-\mathrm{H}_{2} \mathrm{O}(85: 15)$ & $\begin{array}{l}\text { solvent partitioning, } \\
\text { preparative TLC }\end{array}$ & $\begin{array}{l}\text { (C18)HPLC-UV } \\
\text { (219nm) }\end{array}$ & $5-10$ & $\begin{array}{c}\text { Steyn } \\
\text { et al, } 1991\end{array}$ \\
\hline $\begin{array}{l}\text { wheat, } \\
\text { wheat products }\end{array}$ & $\begin{array}{c}\mathrm{CH}_{3} \mathrm{CN}-\mathrm{H}_{2} \mathrm{O} \\
(84: 16)\end{array}$ & $\begin{array}{l}\text { activated charcoal- } \\
\text { alumina column }\end{array}$ & $\begin{array}{l}\text { (C18)HPLC-UV } \\
\text { (229nm) }\end{array}$ & 30 & $\begin{array}{c}\text { Steyn } \\
\text { et al, } 1991\end{array}$ \\
\hline wheat & $\begin{array}{l}\mathrm{MeOH}-\mathrm{H}_{2} \mathrm{O} \\
(1: 1)\end{array}$ & $\begin{array}{l}\left(\mathrm{NH}_{4}\right)_{2} \mathrm{SO}_{4} \\
\text { solvent partitioning, } \\
\text { Si-gel column }\end{array}$ & $\begin{array}{c}\text { GC-ECD } \\
\text { HFB derivatives }\end{array}$ & 10 & $\begin{array}{l}\text { Richard } \\
\text { et al, } 1993\end{array}$ \\
\hline corn, barley & $\underset{(95: 5)}{\mathrm{MeOH}-\mathrm{H}_{2} \mathrm{O}}$ & $\begin{array}{l}\text { AmberlitreXAD-4, } \\
\text { Florisil column }\end{array}$ & GC-FID & 2 & $\begin{array}{l}\text { Kamimura } \\
\text { et al, } 1981\end{array}$ \\
\hline cereals & $\begin{array}{c}\mathrm{CH}_{3} \mathrm{CN}-\mathrm{H}_{2} \mathrm{O} \\
(3: 1)\end{array}$ & $\begin{array}{l}\text { solvent partitioning, } \\
\text { Florisil column }\end{array}$ & $\begin{array}{c}\text { GC-ECD } \\
\text { MS-TMS derivatives }\end{array}$ & 2 & $\begin{array}{l}\text { Tanaka } \\
\text { et al, } 1985\end{array}$ \\
\hline
\end{tabular}


chemistry of absorptive materials for column packing and in the efficiency of detectors have increased both the sensitivity and the reproducibility of this technique making it particularly suitable for the analysis of complex matrices such as extracts from cereal and mixed feeds. Polar solvents are most commonly used for the separation of DON by reversed-phase chromatography, mostly on C18 columns (RP-18). DON-type toxins, as indicated above, have a fairly weak UV absorption and are non-fluorescent. It nevertheless, is possible to quantitate low concentration of these toxins by the use of a highly sensitive UV detector at wavelength from 219 to $225 \mathrm{~nm}$ (Bennett et al, 1990). The minimum concentration of DON detected in maize using HPLC was $5-10 \mathrm{ng} / \mathrm{g}$ (Steyn et al, 1991). The HPLC method also requires that the sample be subjected to extensive cleanup treatment before it can be analyzed. The cleanup treatments normally involve liquid-liquid partition; column chromatography using a cation-exchange or alumina-carbon columns followed by further cleanup on a carbon-celite minicolumn; or precipitation (Lauren et al, 1987). The major negative aspect for the use of HPLC is the high instrumentation cost (Steyn et al, 1991).

GC, although not commonly used for other mycotoxin analysis, is the most effective method for the detection of the trichothecene group of mycotoxins, including DON and T-2 toxin. In this procedure, the volatility of the toxins must be increased by derivatization prior to GC analysis. Heptafluro-butyrylimidazole (HFB) is frequently used as the derivatizing agent. The use of capillary columns which have superior resolving power, electron capture detectors (ECD) and HFB derivatizing agents have dramatically increased the sensitivity of the assay with the detection limits for DON being 
as low as $2 \mathrm{ng} / \mathrm{g}$ in cereals (Steyn et al, 1991).

MS is especially useful for the detection of compounds that lack a chromophore group, such as T-2 toxin. Recently, GC-MS and HPLC-MS methods which combined liquid chromatography with MS have been used for DON quantitation as they have the advantage of being able to verify the identity of the toxin. MS is also one of the methods recommended for DON determination in cereals (Steyn et al, 1991). All above methods have common disadvantages as they require tedious cleanup treatments, trained personnel and expensive instruments which are only available in well equipped laboratories.

\section{Immunochemical assays for the determination of DON and 3-DON in agricultural commodities}

The development of immunochemical assays has had an immense impact in many areas, including medicine, agriculture and environmental science. The wide acceptance of this technique as an analytical tool for the screening of mycotoxins in agricultural commodities have been facilitated by the improvements in methodology during the last decade (Chu, 1991a). Immunoassays offer advantages which overcome the difficulties encountered with the physicochemical and biological methods as they are simple, rapid, specific and sensitive. They can be prepared in commercially available kit format for large-scale, routine sample testing and can be readily used in analytical laboratories, in grain elevators or on the farms.

\subsection{General principles for the development of immunochemical assays}


Immunochemical assays for mycotoxin analysis depend on the interaction of specific antibodies with mycotoxins, with the extend of the reaction being monitored by the use of a labelled marker (Candlish, 1991). Antibodies are defined as glycoprotein that exhibit the properties of immunoglobulin and are secreted into the body fluid by plasma B cells of host animals in response to the challenge of a foreign material called an "immunogen" or "antigen" (Candlish, 1991 and Pestka, 1988). Antibodies exhibit exquisite specificity and can discriminate minor differences in chemical structures, such as the location or presence of a side group (hydroxy group, carbonyl group, ester group, etc) of the immunogen (Pestka, 1988). Reagents required to develop and perform an immunoassay for a mycotoxin analysis generally include a toxin-protein conjugate as the immunogen for antibody production, specific antibodies against the toxin, a labelled marker, standard preparations of the toxin, an assay system that can separate the bound immunoreactant from the free reactant and a detection system to measure the extend of the antibody-toxin reaction (Howanitz, 1988).

\subsection{Types of immunochemical assays used for the determination of mycotoxins} (Figure 3)

The most common immunoassays used for mycotoxins are radioimmunoassays (RIA) and enzyme-immunoassays (EIA). The RIA was first developed in 1959 for detection of human insulin (Yalow and Berson, 1959). It involves the use of a constant amount of radioactive mycotoxin marker incubated with the toxin-specific antibody in the presence of various amounts of toxin standards or unknown samples (Pestka, 1988). After separation of free and bound toxin, radioactivity in one of the fractions is 
Figure 3. Immunochemical assays for mycotoxins.

I. competitive radioimmunoassay (RIA). Mycotoxin-specific antibody (AB) is incubated with constant amount of tritiated toxin $(\mathrm{H})$ in presence of varying amount of toxin standard or unknown sample ( $\bullet$ ); complex is removed from solution and the toxin content is determined based on the radioactivity of labelled toxin. II. Direct competitive ELISA. Toxin specific antibody $(A B)$ is immobilized on solid phase; mycotoxin-enzyme labelled conjugate (ENZ- $\bullet$, assay antigen) is simultaneously incubated with free toxin standard or test sample $(\diamond)$ over the solid phase-bound antibody $(\mathrm{AB})$; free toxin concentration is inversely related to the enzyme labelled conjugate bound to the solid phase and, thus, can be calculated on the development of end product absorbance obtained after addition of enzyme substrate (S). III. Indirect competitive ELISA. Mycotoxin-carrier protein conjugate (CP- $\bullet$, coating antigen) is immobilized on the solid phase; toxin-specific antibody $(\mathrm{AB})$ competes with free toxin in solution $(\bullet)$ for binding to the solid phase-bound toxin conjugate (CP- $\bullet$ ); enzyme labelled second anti-immunoglobulin antibody (ENZ-ab) is then required to determined the total amount of solid phase-bound antibody; free toxin concentration is inversely related to the amount of enzyme labelled antibody which is quantitated by the absorbance of end product obtained after addition of enzyme substrate (S). (Adapted from Pestka, 1988) 

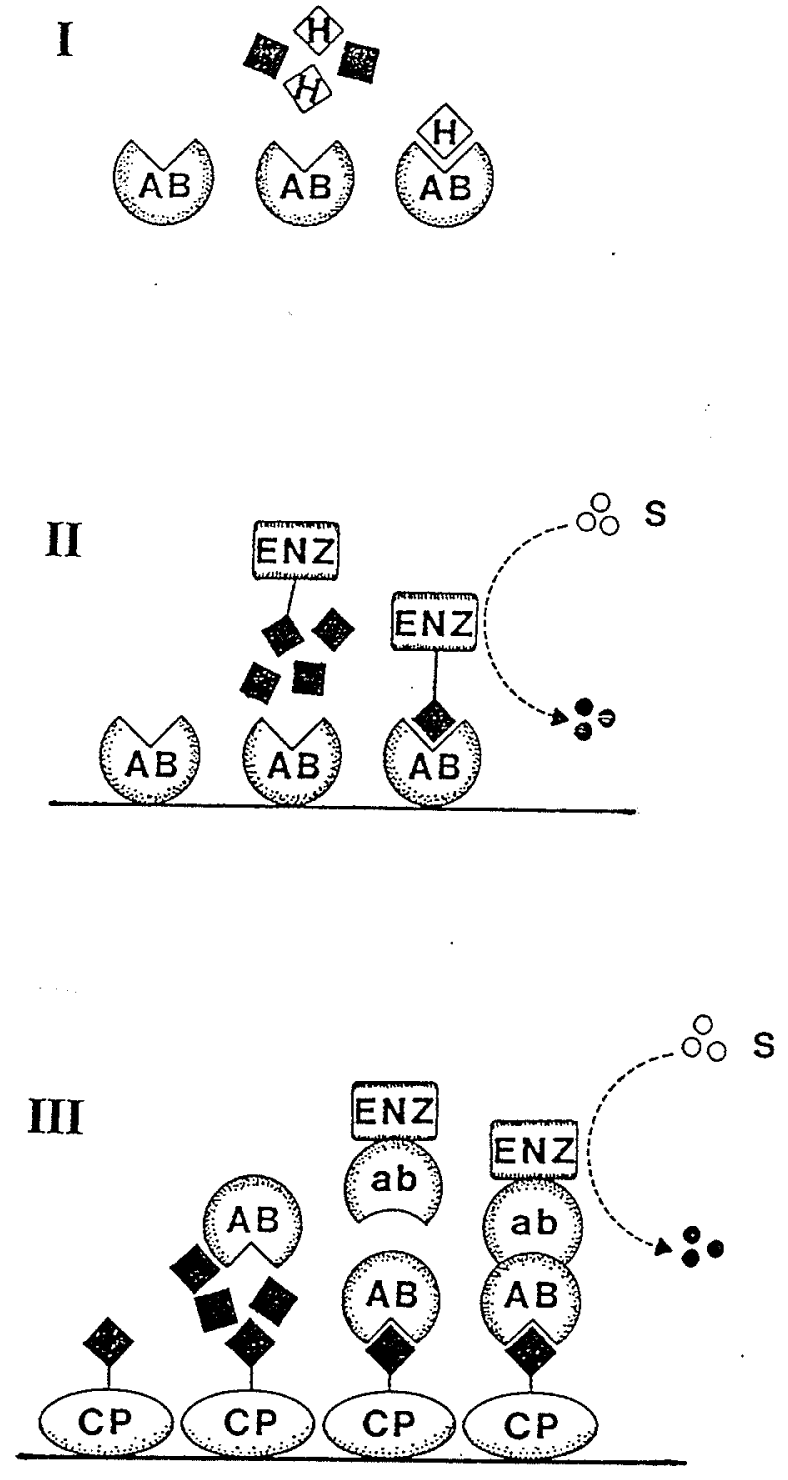
determined. In this method, the specific activity of the radioactive ligand plays an essential role in the sensitivity of the assay. Both tritiated and iodinated mycotoxin derivatives have been used (Chu, 1991b). The detection limit of RIA for DON in wheat and corn using tritiated DON-triacetate and antibodies against acetyl-DON was reported to be $20 \mathrm{ng} / \mathrm{g}$ (Xu et al, 1986). Although RIA is a simple, sensitive and accurate method for toxin analysis, it has limited application as it requires the use of radioactive materials, which need to be properly disposed of, and costly radioisotope measuring instruments (Chu, 1991b).

The commonly used EIA for mycotoxins is the competitive enzyme-linked immunosorbent assay (ELISA). This type of assay was first developed in 1971 by Engvall and Perlman (1971). It offers the simplest alternative for the screening of toxins in food samples. Two types of heterologous ELISAs are commonly used: the direct antigen capture ELISA and the indirect antibody capture ELISA (Figure 3). In the direct competitive antigen capture ELISA, specific anti-toxin antibodies are initially immobilized on a solid-phase, such as the wells of a microtiter plate, the walls of tubes or on nylon beads. The microtiter plate approach has particular advantages because of the availability of multi-well pipetors, washers and spectrophotometers that can be used to automate the assay. The bound antibody is then incubated simultaneously with a toxin-enzyme conjugate (assay antigen) and the solutions of standard toxin or the unknown samples. Although horseradish peroxidase (HRP) is most commonly used as the enzyme for the assay antigen, other enzymes such as alkaline phosphatase (AP) and B-galactosidase are also available (Chu, 1991b). This assay is based on the competition 
between a free mycotoxin and an enzyme-labelled mycotoxin for the same antibody binding sites. Thus, the amount of free toxin (either in the standards or in samples) is inversely related to the amount of antibody-bound enzyme conjugate, which can be measured spectrophotometrically by the intensity of color development after the addition of the substrate (Pestka, 1988 and Candlish, 1991).

In the indirect antibody capture ELISA, a mycotoxin-protein conjugate (coating antigen) is first coated onto a solid-phase and incubated with toxin-specific antibody in the presence of the standard or test toxin. The amount of antibody bound to the immobilized coating antigen is then determined by reaction with an enzyme-labelled second antibody, which is commercially available. In this assay, toxin in the standards or samples compete with the immobilized toxin for the binding sites of the specific antibody in solution (Chu, 1991b). Again, the concentration of the free toxin (present in either standards or samples) is inversely proportional to the amount of coating antigenbound antibody, which is indicated by the absorbance $(\mathrm{A})$ of the colored product. Of the two ELISAs, the direct antigen capture ELISA is preferred for mycotoxin analysis because it utilizes an enzyme-labelled toxin conjugate, requiring one less incubation and washing step. It therefore involves shorter assay periods and has somewhat less variability than the indirect format (Pestka, 1988). However, the sensitivity of the latter ELISA is slightly better than that of the former one, in addition to the advantage of requiring less antibody. Another ELISA format is the modified indirect antibody capture ELISA using enzyme-labelled toxin-specific antibody, which make it possible to detect the coating antigen-bound antibody without having to use a secondary antibody. This 
assay procedure combines the advantages of both direct and indirect ELISAs as it can shorten the assay time without sacrificing sensitivity (Chu, 1991b).

Several new immunochemical approaches for mycotoxin analysis have been developed recently such as the affinity column technique, called the "hit-and-run" test and the quick screening tests which use an alternative solid-phase, such as plastic cards, plastic cups or dip-sticks in the test. These quick screening tests have similar principles to the direct antigen capture ELISA and have been used in commercial test kits for the rapid (less than 10 minutes) and semiquantitative monitoring of mycotoxins under field conditions (Chu, 1991b).

\subsection{Preparation of toxin-protein conjugates for immunization}

The development of immunoassays for mycotoxins involves several steps. The first step is the synthesis of immunogenic antigens by conjugation of the toxin to protein carriers. The immunogen required to initiate the antibody response should be a complex molecule having a high molecular weight ( $>10,000$ Daltons). Mycotoxins are low molecule weight (300-400 dalton), non-immunogenic molecules (haptens) which by themselves cannot elicit an antibody response but will bind to antibodies once they are formed. Thus, in most cases, they must be covalently bound to a carrier protein, polypeptide or other macromolecules to elicit an immune response. Bovine serum albumin (BSA), human serum albumin (HSA), ovalbumin (OVA), keyhole limpet hemocyanin (KLH) and polylysine (PLL) are often used as the protein carriers (Chu, 1991b).

DON and 3-AcDON molecules have carbonyl and hydroxy side groups that can 
be utilized in conjugation reactions. These groups, however, need to be converted into more reactive groups such as an amino or carboxylic group for the conjugation reaction. These derivatives can then react with the carboxylic or amino groups on carrier proteins. The orientation of the toxin to a protein molecule is critical in determining the specificity of the resulting antibody as the moieties that project most distantly from the conjugating site, tends to be immunodominant and typically induce the most successful antibody response. Therefore, the appropriate selection of the site for the chemical conjugation of the toxin and the introduction of a rigid, alkyl spacer bridge between the toxin and protein will have the additional advantage of improving the quantity and quality of antibody production (Pestka, 1988).

Standard procedures that have been used to derivatize the carbonyl or hydroxyl groups of other haptens such as steroids, drugs or other mycotoxins can also be used for the derivatization of DON and 3-AcDON. The most commonly used method is esterification of the hydroxy group of the toxin with bifunctional anhydrides, like succinic acid or glutaric acid anhydrides to form the corresponding hemisuccinate (HS) or hemiglutarate (HG) derivatives of the toxin (Chu, 1991b). Alternative methods like carboxymethyloximation of the carbonyl group of the toxin with carboxymethoxylamine hemihydrochloride to form toxin-carboxymethyl oxime (CMO) derivatives (Bayard et al, 1970 and Colburn, 1975) have been used on DON (Casale et al, 1986). Furthermore, other methods such as carboxymethylation of the primary hydroxyl group of the molecule with haloacid to form carboxymethylated hapten have been used for ficoll (Inman, 1975) and T-2 derivatization (Xiao et al, 1995). In the reaction with the hydroxy groups of 
DON, derivatization should involve extensive chemical protection because of the presence of multiple hydroxy groups (Casale et al, 1988 and Miles et al, 1990), while it is unnecessary in the case of 3-AcDON (Kemp et al, 1986 and Usleber et al, 1991).

Derivatives of DON or 3-ACDON which contains a bridging group containing an active carboxylic group $(-\mathrm{COOH})$ can therefore be chemically linked to the carrier protein. Among the several conjugation methods, two methods are commonly used in the development of ELISAs for DON toxins. They are the active ester (AE) method which involves the reaction of the toxin derivative and protein with $\mathrm{N}$ hydroxysuccinimide (NHS) in the presence of dicyclohexylcarbodiimide (DCC) (Casale et al, 1988 and Xu et al, 1988) and the mixed anhydride (MA) method which involves the activation of toxin- $\mathrm{COOH}$ derivative with isobutyl chloroformate followed by the reaction with the amino group of protein (Mills et al, 1990 and Kemp et al, 1986). Alternatively, the water-soluble carbodiimide (WSC) method in which the toxin derivative reacts with a protein carrier in the presence of a coupling reagent such as EDPC and the Mannish reaction which uses formaldehyde as the cross-linking reagent has been used for the preparation of conjugates of other toxins (Chu, 1991b).

\subsection{Production and characterization of specific antibodies against DON or 3-} AcDON

Polyclonal antibody (PAb) is the type of antibody that is frequently used in ELISA for DON or 3-AcDON determination (Mills et al, 1990, Kemp et al, 1986 and Usleber et al, 1991). Production of toxin specific pAb can be achieved by immunizing animals with a toxin-carrier conjugate at multiple-site, followed by boosting at 3-5 week intervals 
and by separating antisera from the collected blood. Antisera produced by this procedure is defined as polyclonal because the immunoglobulins are derived from multiple lymphocyte clones and thus, are the sum of subpopulations of antibodies having a variety of affinity and specificity. Production of polyclonal antibodies is relatively simple and the affinity of this type of antibody is generally high (Chu, 1991b). Normally, rabbits are the host commonly used for the production of anti-DON antibodies (Mills et al, 1990, Kemp et al, 1986 and Usleber et al, 1991). Recently, polyclonal antibodies specific to ochratoxin A and T-2 toxin have been successfully developed in laying hens (Clarke et al, 1993 and Kierek-Jaszczuk et al, 1995). Laying hens can transfer their antibodies (IgY) from serum to the egg yolk to protect their offspring. Such antibodies offer advantages in that they are suitable for the production of large quantities of antibodies and can be harvested non-invasively from the eggs of the host.

An alternative approach of antibody production is the development and screening of stable hybridoma cell lines by fusing spleen cells of toxin-immunized mice with myeloma cells. The resulting immortal hybridoma cell lines are capable of secreting specific DON antibodies with unique properties, referred to as "monoclonal antibody" (Casale et al, 1986 and Abouzied et al, 1991b). Monoclonal antibodies yield highly reproducible results in the test and tend to be highly specific for a given determinant whereas polyclonal antibodies tend to interact with multiple determinants on the immunogen. However, the disadvantages of monoclonal antibody production such as the cost, effort and the requirement of tissue culture facilities for antibody production need to be considered (Candlish, 1991). The characterization of the antibodies in term of their 
titer, specificity and sensitivity is important and should be conducted before they are used for the development of the assay.

\subsection{Performance criteria of immunoassay for mycotoxins}

Reliable immunoassays for mycotoxins should be simple, rapid, quantitative, sensitive, specific and reproducible. The sensitivity of immunoassays depends predominantly on the affinity of the antibody employed in the assay (Howanitz, 1988). It is normally defined as the detection limit which is the lowest concentration of toxin that is able to significantly inhibit the binding of the antibody in the competitive ELISA. This significant inhibition is usually calculated as twice the standard deviation (SD) that is obtained when the maximum amount of antibody is bound; i.e., the 2SD of the readout signal obtained in the absence of free toxin. Sensitivity can also be assessed from the slope of the standard inhibition curve and the $\mathrm{IC}_{50}$ value which is the concentration of toxin required to give $50 \%$ inhibition. Improvements in sensitivity can be obtained by optimizing the concentrations of the assay antigen/coating antigen and antibodies that are employed and by using the combinations of appropriate assay/coating antigen and antisera (Wei et al, 1984).

The specificity of the immunoassays depends primarily on the specificity of the antisera (Howanitz, 1988). The specificity of an antiserum can be express as the crossreactivity and is assessed by comparing the $\mathrm{IC}_{50}$ value for metabolites, analogues or structurally similar compounds with that of the parent toxin from which the antibody was raised (Candlish, 1991). A high degree of cross-reactivity of the antibody with other co-occurring compounds will reduce the specificity and quantitative nature of the assay. 
Nevertheless, it also can be of advantage as the antibody can be used, under these conditions, as in multi toxin screening assay. Nicol et al (1988) reported that antibodies against DON that have a high degree of cross-reactivity with 3-AcDON and 15-AcDON can be used to quantitate the acetylated forms of DON.

\subsection{Preparation of toxin-protein conjugates for use as the assay/coating antigen in ELISAs}

The immunization of animals with a hapten-protein conjugate for the purpose of generating toxin-specific antisera results in the production of antibodies with multiple specificities directed against the different epitopes present on the parent antigen. These antibodies are polyclonal and are the sum of subpopulations of antibodies. They may recognize the hapten, the carrier protein, the chemical bridging group or parts of these components in the antigen. The assay antigen (i.e., the hapten-enzyme conjugate that is used in direct antigen capture ELISA) or the coating antigen (i.e., the hapten-protein conjugate that is used in indirect antibody capture ELISA) that share the same determinants as the immunogen should therefore have a higher binding affinity for the antibody than the free hapten. As a results there will be a loss in the sensitivity and precision of the assay (Nordblom et al, 1981).

It is also well known that the use of a heterologous protein carrier and a different conjugating chemistry for the preparation of the assay (coating) antigen compared to that used for the immunogen can greatly reduce the nonspecific binding of antibody to the carrier protein as this approach removes a large portion of the corresponding antibodies from the assay system (Clarke et al, 1993 and Usleber et al, 1991). It is quite effective 
especially when the hapten has a functional group that can readily be coupled to a protein without the introduction of any additional bridging groups into the conjugate.

However, if a chemical linkage is involved in the hapten-protein preparation, such as in the case of DON and 3-AcDON, antibodies would also recognize the linkage group if it was the same in both the immunogen and the assay (coating) antigens. The ability of the antiserum to recognize this bridging group can result in a high uninhibitable background or even complete lack of inhibition in the competitive ELISA when a conjugate with a heterologous carrier but a homologous bridge is used for the assay (coating) antigen. Such a phenomenon was first observed in the steroid ELISA (Nordblom et al, 1981) and subsequently found in many other ELISAs for small molecules, such as benzoyphenylurea insecticides, $s$-triazine herbicide, sulfonamides, parathion and T-2 toxin (Wei et al,1984, Goodrow et al, 1990, Vallejo et al, 1982, Sheth et al, 1991 and Kierek-Jaszczuk et al, 1995). Several strategies have been investigated in an effort to eliminate the binding of the bridging group by the antiserum. One of them is to keep the homologous chemical linkage bond in the assay/coating antigen, but to alter the length of the bridge in the assay (coating) antigen. Such an approach has been used in most DON and 3-AcDON ELISAs (Kemp et al, 1986 and Nicol et al, 1993). Another is to use a heterologous bridge assay/coating antigen in comparison to the immunogen. This can be achieved by either changing the chemical bond between the hapten and the protein or changing the site for the conjugate of the hapten. It is therefore possible to eliminate the interference that results from the recognition of the bridging groups by the use of a the heterologous assay/coating antigen. 


\subsection{Quantative ELISAs for 3-AcDON, DON and other DON analogs}

There have been a number of difficulties encountered in the generation of antibodies against DON. These problems are related both to the chemistry of the molecule which makes selective derivatization difficult and also to the apparent low immunogenic responses of the toxin conjugate (Nicol et al, 1993). For example, no antibodies against DON were obtained in rabbits immunized with DON-CMO-BSA (Zhang et al,1986) while antibodies against 3-AcDON had a low affinity for DON (Kemp et al, 1986). Nevertheless, several ELISAs using polyclonal or monoclonal antibodies have been described for the determination of DON in agriculture commodities including two for 3-AcDON and three for 15-AcDON. These methods have been used for analysis of the toxin in rice, wheat and corn (Table 4 and 5). The lowest reported detection limit using polyclonal antibodies is $90 \mathrm{pg} / \mathrm{well}(0.45 \mathrm{ng} / \mathrm{ml})$ for DON (Mills et al, 1990) and $0.05-1 \mathrm{ng} / \mathrm{ml}$ for 3-AcDON (Usleber et al, 1991 and Kemp et al, 1986). The sensitivity of DON assay using monoclonal antibodies is much lower, ranging from 125 to $200 \mathrm{ng} / \mathrm{ml}$ (Casale et al, 1988 and Nicol et al, 1993). The cross-reactivity of 3AcDON and other acetyl forms of DON with antibodies against DON are usually high (Casale et al, 1988, Abouzied et al, 1991b and Nicol et al, 1993) while anti-3-AcDON antibodies barely react with DON but react strongly with acetylated DON (Usleber et al, 1991).

Further research on the development of immunoassays for DON-type toxins could involve the use of either chicken $\operatorname{IgY}$ or rabbit $\operatorname{IgG}$ as the sources of polyclonal antibody production and the development of immunoassays which are more accurate and reliable 
and not only would simultaneously screen for all of the DON toxins but also could specifically identify the individual form of the mycotoxin. The research presented in this thesis provides potential solutions to some of the problems, involved in the development of an ELISA for DON-type toxins and addresses the methodology for an improvement in the sensitivity and specificity of an ELISA for 3-AcDON. 
F Table 4. Quantitative Immunoassays (RIA and ELISA) for Deoxynivalenol (DON) Using Rabbit Polyclonal Antibodies $(\mathrm{Pab})$ and Mouse Monoclonal Antibodies (MAb)

\begin{tabular}{|c|c|c|c|c|c|c|}
\hline $\begin{array}{l}\text { Sample } \\
\text { matrix }\end{array}$ & $\begin{array}{c}\text { Extraction } \\
\text { slovent }\end{array}$ & $\begin{array}{l}\text { Antibodies } \\
\text { employed }\end{array}$ & Assay formt & $\begin{array}{l}\text { Detection } \\
\text { limits }\end{array}$ & cross-ractivity & Reference \\
\hline $\begin{array}{l}\text { buffer } \\
\text { solutions }\end{array}$ & - & $\begin{array}{c}\text { rabbit PAb } \\
\text { anti-triacetylDON }\end{array}$ & RIA & $0.5 \mathrm{ng} / \mathrm{ml}$ & $\mathrm{ND}^{*}$ & $\begin{array}{l}\text { Zhang } \\
\text { et al, } 1986\end{array}$ \\
\hline $\begin{array}{l}\text { wheat } \\
\text { corn }\end{array}$ & $\begin{array}{c}\mathrm{CH}_{3} \mathrm{CN}-\mathrm{H}_{2} \mathrm{O} \\
(84: 16)\end{array}$ & $\begin{array}{c}\text { rabbit PAb } \\
\text { anti-triacetylDON }\end{array}$ & RIA & $20 \mathrm{ng} / \mathrm{g}$ & - & $\begin{array}{l}\text { Xu et al, } \\
1986\end{array}$ \\
\hline $\begin{array}{c}\text { buffer } \\
\text { solutions }\end{array}$ & - & $\begin{array}{l}\text { mouse MAb } \\
\text { anti-DON }\end{array}$ & $\begin{array}{c}\text { ELISA } \\
\text { indirect } \\
\text { direct }\end{array}$ & $\begin{array}{l}0.2-0.5 \mu \mathrm{g} / \mathrm{ml} \\
0.2-2.0 \mu \mathrm{g} / \mathrm{ml}\end{array}$ & $\begin{array}{l}\text { highly react with } \\
\text { 3-AcDON }\end{array}$ & $\begin{array}{c}\text { Casale } \\
\text { et al, } 1988\end{array}$ \\
\hline $\begin{array}{l}\text { corn } \\
\text { wheat }\end{array}$ & $\begin{array}{c}\mathrm{CH}_{3} \mathrm{CN}-\mathrm{H}_{2} \mathrm{O} \\
(84: 16)\end{array}$ & $\begin{array}{c}\text { rabbit PAb } \\
\text { anti-triacetylDON }\end{array}$ & $\begin{array}{l}\text { ELISA } \\
\text { indirect }\end{array}$ & $10 \mathrm{ng} / \mathrm{ml}$ & react with $15-\mathrm{AcDON}$ & $\begin{array}{l}\text { Xu et al, } \\
1988\end{array}$ \\
\hline wheat & $\begin{array}{c}\mathrm{MeOH}-\mathrm{H}_{2} \mathrm{O} \\
(60: 40)\end{array}$ & $\begin{array}{c}\text { rabbit PAb } \\
\text { anti-DON }\end{array}$ & $\begin{array}{l}\text { ELISA } \\
\text { indirect }\end{array}$ & $\begin{array}{c}0.45 \mathrm{ng} / \mathrm{ml} \\
100 \mathrm{ng} / \mathrm{g}\end{array}$ & ND & $\begin{array}{c}\text { Mills et al, } \\
1990\end{array}$ \\
\hline $\begin{array}{l}\text { buffer } \\
\text { solutions }\end{array}$ & - & $\begin{array}{l}\text { mouse MAb } \\
\text { anti-DON }\end{array}$ & ELISA indirect & $\begin{array}{c}\mathrm{IC}_{50}= \\
1360 \mathrm{ng} / \mathrm{ml}\end{array}$ & $\begin{array}{l}\text { highly react with } \\
\text { 3-AcDON }\end{array}$ & $\begin{array}{l}\text { Abouzied et } \\
\text { al, 1991b }\end{array}$ \\
\hline $\begin{array}{l}\text { buffer } \\
\text { solutions }\end{array}$ & - & $\begin{array}{l}\text { rabbit PAb } \\
\text { anti-DON }\end{array}$ & ELISA direct & $1.0 \mathrm{ng} / \mathrm{ml}$ & $\begin{array}{l}\text { highly react with } \\
\text { 3-AcDON }\end{array}$ & $\begin{array}{l}\text { Usleber } \\
\text { et al, } 1981\end{array}$ \\
\hline $\begin{array}{l}\text { corn } \\
\text { wheat }\end{array}$ & $\begin{array}{l}\mathrm{MeOH}-\mathrm{H}_{2} \mathrm{O} \\
(9: 1)\end{array}$ & $\begin{array}{c}\text { mouse MAb } \\
\text { anti-DON }\end{array}$ & ELISA direct & $\begin{array}{l}50 \mathrm{ng} / \mathrm{ml} \\
250 \mathrm{ng} / \mathrm{g}\end{array}$ & react with $15-\mathrm{AcDON}$ & $\begin{array}{l}\text { Sinha et al, } \\
\quad 1985\end{array}$ \\
\hline $\begin{array}{c}\text { buffer } \\
\text { solutions }\end{array}$ & - & $\begin{array}{l}\text { mouse MAb } \\
\text { anti-DON }\end{array}$ & $\begin{array}{l}\text { ELISA } \\
\text { indirect }\end{array}$ & $125 \mathrm{ng} / \mathrm{ml}$ & $\begin{array}{l}\text { react with } 3-A c D O N \\
\text { and } 15-A c D O N\end{array}$ & $\begin{array}{l}\text { Nicol et al, } \\
1985\end{array}$ \\
\hline
\end{tabular}


Table 5. Quantitative Immunoassays (ELISAs) for 3-Acetyldeoxynivalenol (3-AcDON) and 15-Acetyldeoxynivalenol (15-

AcDON) Using Rabbit Polyclonal Antibodies (PAb) or Mouse Monoclonal Antibodies (MAb)

\begin{tabular}{|c|c|c|c|c|c|c|}
\hline $\begin{array}{l}\text { Sample } \\
\text { matrix }\end{array}$ & $\begin{array}{c}\text { Extraction } \\
\text { slovent }\end{array}$ & $\begin{array}{l}\text { Antibodies } \\
\text { employed }\end{array}$ & Assay formt & Detection limits & $\begin{array}{c}\text { Antibody } \\
\text { cross-reactivity }\end{array}$ & Reference \\
\hline rice & $\begin{array}{c}\mathrm{MeOH}-\mathrm{H}_{2} \mathrm{O} \\
(60: 40)\end{array}$ & $\begin{array}{c}\text { rabbit PAb } \\
\text { anti-3-AcDON }\end{array}$ & $\begin{array}{c}\text { ELISA } \\
\text { direct }\end{array}$ & $1 \mathrm{ng} / \mathrm{g}$ & NDwith DON & $\begin{array}{l}\text { Kemp et al, } \\
1986\end{array}$ \\
\hline $\begin{array}{l}\text { buffer } \\
\text { solutions }\end{array}$ & - & $\begin{array}{c}\text { rabbit PAb } \\
\text { anti-DON } \\
\text { anti-3-AcDON }\end{array}$ & $\begin{array}{r}\text { ELISA } \\
\text { direct }\end{array}$ & $\begin{array}{l}0.05 \mathrm{ng} / \mathrm{ml} \\
0.1 \mathrm{ng} / \mathrm{ml}\end{array}$ & $\begin{array}{l}\text { ND with DON } \\
\text { or } 15-\mathrm{AcDON}\end{array}$ & $\begin{array}{c}\text { Usleber et al, } \\
1991\end{array}$ \\
\hline $\begin{array}{c}\text { buffer } \\
\text { solutions }\end{array}$ & - & $\begin{array}{l}\text { mouse MAb } \\
\text { anti-DON }\end{array}$ & $\begin{array}{c}\text { ELISA } \\
\text { indirect }\end{array}$ & $\begin{array}{c}\mathrm{IC}_{50}= \\
10 \mu \mathrm{g} / \mathrm{ml}\end{array}$ & $\begin{array}{l}\text { high reactivity } \\
\text { with 3-AcDON } \\
\text { and 15-AcDON }\end{array}$ & $\begin{array}{l}\text { Nicol et al, } \\
\quad 1993\end{array}$ \\
\hline wheat & $\mathrm{MeOH}$ & $\begin{array}{c}\text { rabbit PAB } \\
\text { anti-15-AcDON }\end{array}$ & $\begin{array}{l}\text { ELISA } \\
\text { direct }\end{array}$ & $0.35 \mathrm{ng} / \mathrm{ml}$ & $\begin{array}{l}\text { high reactivity with } \\
3,15 \text {-diacDON }\end{array}$ & $\begin{array}{c}\text { Usleber et al, } \\
1993\end{array}$ \\
\hline corn, wheat & $\begin{array}{c}\mathrm{MeOH}-\mathrm{H}_{2} \mathrm{O} \\
1: 9\end{array}$ & $\begin{array}{l}\text { mouse MAb } \\
\text { anti-DON }\end{array}$ & $\begin{array}{c}\text { ELISA } \\
\text { direct }\end{array}$ & $0.05 \mu \mathrm{g} / \mathrm{ml}$ & $\begin{array}{l}\text { high reactivity with } \\
15-\mathrm{AcDON}\end{array}$ & $\begin{array}{l}\text { Sinha et al, } \\
1995\end{array}$ \\
\hline $\begin{array}{l}\text { buffer } \\
\text { solutions }\end{array}$ & - & $\begin{array}{l}\text { mouse MAb } \\
\text { anti-DON }\end{array}$ & $\begin{array}{l}\text { ELISA } \\
\text { indirect }\end{array}$ & $\begin{array}{c}\mathrm{IC}_{50}= \\
0.2 \mu \mathrm{g} / \mathrm{ml}\end{array}$ & $\begin{array}{l}\text { high reactivity } \\
\text { with 3-AcDON } \\
\text { and 15-AcDON }\end{array}$ & $\begin{array}{l}\text { Nicol et al, } \\
1993\end{array}$ \\
\hline
\end{tabular}

' ND, the corss-reactivity was not detectable 


\section{MATERIALS AND METHODS}

\section{Reagents and Materials}

All the organic and inorganic chemicals were analytical grade quality. Human serum albumin (HSA, fraction V), chicken egg albumin (ovalbumin, OVA, grade V), alkaline phosphatase labelled goat anti-rabbit IgG, Tween 20, p-nitrophenyl phosphate ( $p$ NPP) tablets, o-phenylenediamine (OPD) tablets, complete and incomplete Freund's adjuvant (CFA, IFA, respectively), p-anisaldehyde, succinic anhydride, glutaric anhydride, N-hydroxysuccinimide (NHS), iodoacetic acid, 1-methylimidazole, 1,1'carbonyldiimidazole (CDI), recombinant protein G, 15-AcDON, nivalenol (NIV) and all other trichothecenes were purchased from Sigma Chemical Co., St. Louis, MO, USA. DON and 3-AcDON were donations from Dr. D.B. Prelusky, Agriculture Canada, Ottawa. 3-AcDON-HRP conjugate was provided by Dr. D.Kierek-Jaszczuk, Department of Animal Science, University of Manitoba. Carboxymethoxylamine hemihydrochloride and metal sodium were from Aldrich Chemical Co., Milwaukee, WI, USA. Acetic anhydride was purchased from Fisher Scientific Co. Fair Lawn, NJ, USA. Alkaline phosphatase labelled rabbit anti-chicken IgY was obtained from Jackson ImmunoResearch Laboratory Inc., West Grove, PA, USA. D-10 Sephadex G-25M columns were from Pharmacia LKB, Uppsala, Sweden. Flexible silica gel TLC plates G60 F254 were obtained from Whatman International Ltd., Maidstone, England. Microtiter plates (Falcon 3911) were purchased from Becton Dickinson Labware, Oxnard, CA, USA. 


\section{Preparation of Immunogen}

Covalent coupling of 3-AcDON to HSA via a hemisuccinate bridge ( Figure 4.

BI to DI). The toxin was first succinylated at the C-15 position (Usleber et al, 1991) to form 15-O-hemisuccinyl-3-AcDON (3-AcDON-HS, B1) by dissolving $10 \mathrm{mg}$ of 3AcDON in $1 \mathrm{ml}$ pyridine and adding $100 \mathrm{mg}$ of succinic anhydride. The mixture was heated at $100^{\circ} \mathrm{C}$ for $2 \mathrm{hr}$ followed by normal phase (silica) TLC. The chromatography was performed with the developing solvent being a mixture of methanol and chloroform $(1: 9, v / v)$. The toxin and its derivative were visualized by spraying with $10 \%$ sulfuric acid or $20 \%$ aluminum chloride and identified on the basis of their Rf values (Usleber et al, 1991). The toxin derivative, 3-AcDON-HS (B1), was identified when sprayed with aluminum chloride or sulfuric acid as a single blue fluorescent spot or brown spot at Rf 0.7. The Rf value for standard 3-AcDON was 0.8 . The data indicated that the esterification reaction went to completion and that only one of the hydroxyl groups of 3AcDON (C-15) was derivatized (Kamimura et al, 1981). 3-AcDON-HS was then coupled to HSA using the active NHS ester method described by Kitagawa et al. (1981) with a 50:1 molar ratio of toxin to protein carrier. The conjugate was purified by filtration on a PD-10 column equilibrated with PBS buffer (10 mM sodium phosphate containing $154 \mathrm{mM} \mathrm{NaCl}, \mathrm{pH} 7.4$ ), sterilized by passing through a $0.2 \mu \mathrm{m}$ sterile filter and stored at $4^{\circ} \mathrm{C}$ (Kierek-Jaszczuk et al, 1995).

\section{Antibody Production}

For the primary immunization, the immunogen (3-AcDON-HS-HSA, Figure 4. 
Figure 4. Schema for the synthesis of 3-acetyldeoxynivalenol (3-AcDON)-protein conjugates used as the immunogen and coating antigens.

Preparation of the immunogen (3-AcDON-HS-HSA, D1) by coupling succinic anhydride derivatized 3-AcDON (3-AcDON-HS, B1) and HSA using the NHS active ester method; preparation of a homologous linkage coating antigen (3-AcDON-HG-OVA, D2) by coupling glutaric anhydride derivatized 3-AcDON (3-AcDON-HG, B2) and OVA using the CDI method; preparation of heterologous linkage coating antigens (3-AcDONMC-OVA, D3o and 3-AcDON-MC-HSA, D3h) by coupling iodoacetate carboxymethylated 3-ACDON (3-ACDON-MC, B3) with OVA and HSA, respectively, using the CDI method and preparation of a heterologous site and linkage coating antigen (3-ACDON-CMO-OVA, D4) by coupling carboxmethoxylamine activated 3-AcDON (3-AcDON-CMO, B4) and OVA using the CDI method. $\mathrm{A}$ is the parent compound and $\mathrm{C} 1$ to $\mathrm{C} 4$ are the activated forms of the derivatives coupled to protein carriers via NHS or CDI methods. 


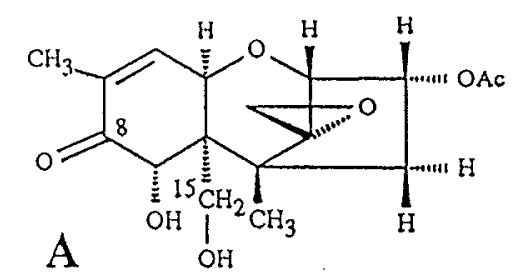

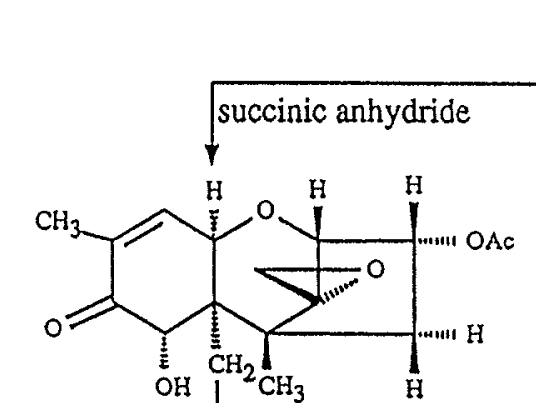

B1

?

$\mathrm{O}=\mathrm{C}-\mathrm{CH}_{2}-\mathrm{CH}_{2}-\mathrm{COOH}$

$\downarrow$ NHS

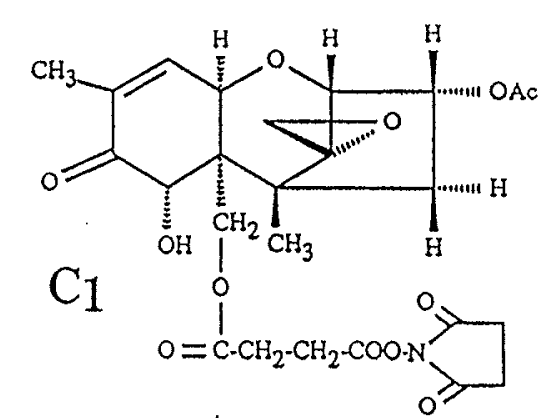

HSA $\mathrm{NH}_{2}$

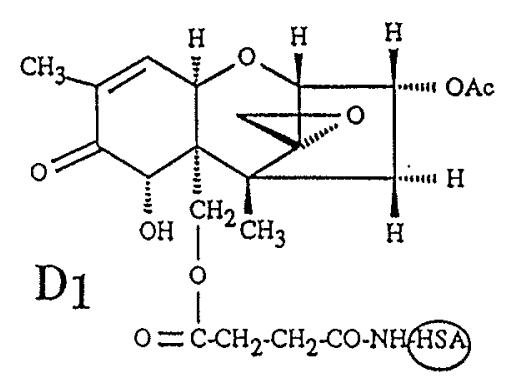

$\mathrm{OH}$

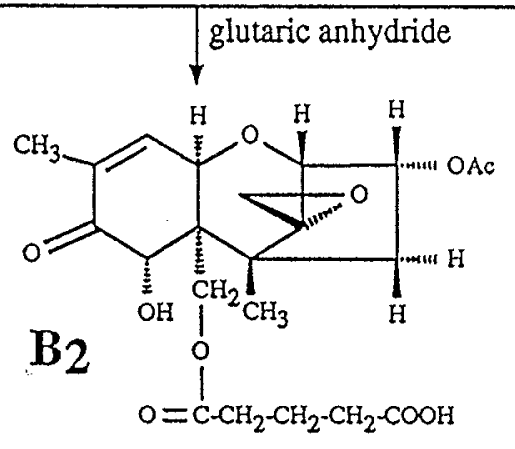

$\downarrow \mathrm{CDI}$

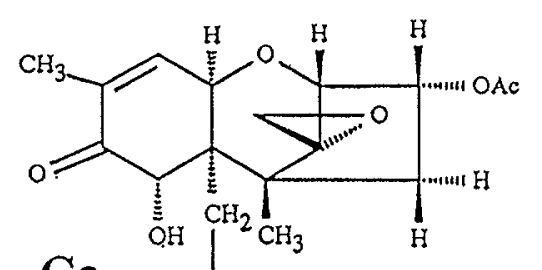

$\mathrm{C}_{2}$

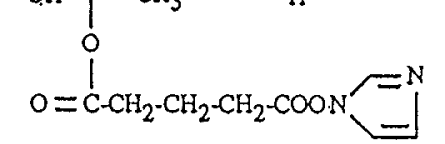

(OVA) $\mathrm{NH}_{2}$

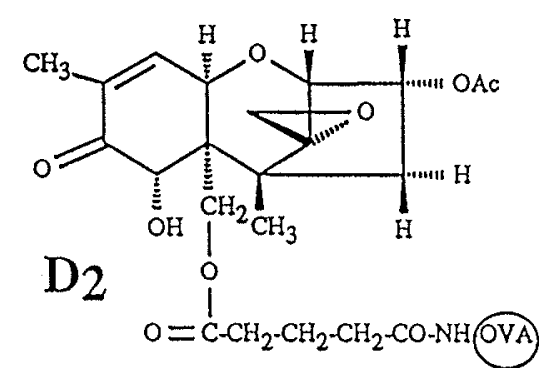

iodoacetic acid

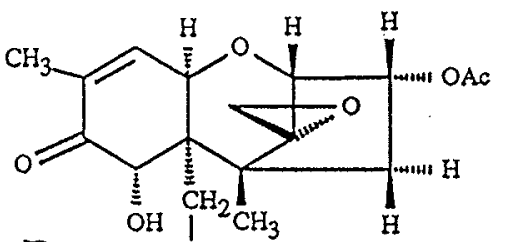

B3

i

$\mathrm{CH}_{2}-\mathrm{COOH}$

CDI

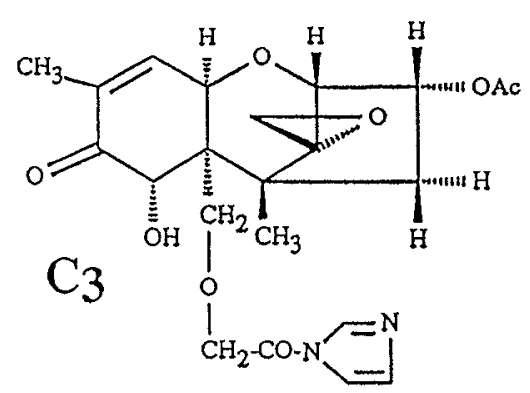

(2ROT) $\mathrm{NH}_{2}$

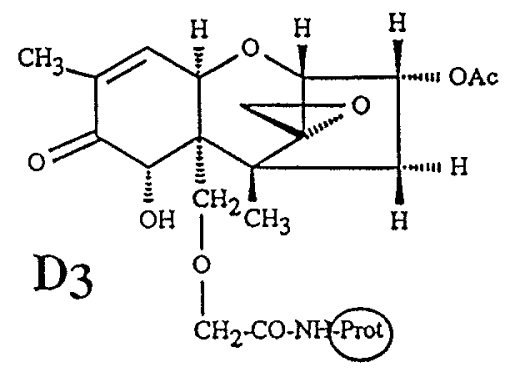

Prot $=$ HSA (D3b)

= OVA. (D30) o-carboxymethoxylamine

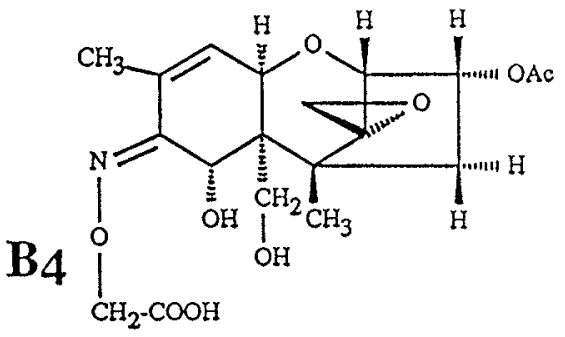

$\downarrow$

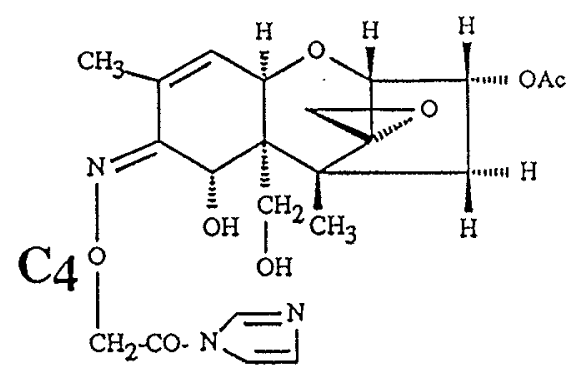

(OVA $\mathrm{NH}_{2}$

D4

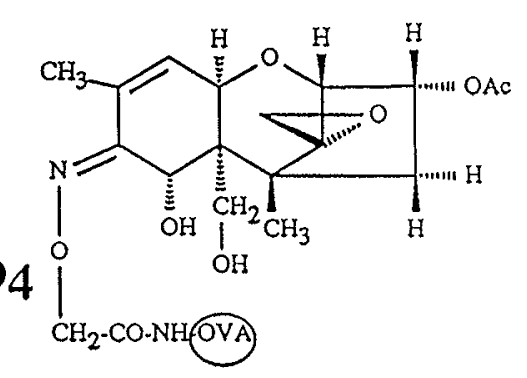


D1) was emulsified with CFA $(1: 2, v / v)$. Each of four Dutch-belted rabbits and four white Leghorn laying hens was immunized with $250 \mu \mathrm{g}$ of conjugate by multisite intradermal injections. Animals were boosted intramuscularly at four to five weeks intervals with $125 \mu \mathrm{g}$ of the same immunogen mixed with IFA. Blood was collected from the marginal ear vein two weeks after each boosting. After coagulation, sera were isolated by centrifugation, aliquoted into $0.5 \mathrm{ml}$ portions and stored at $-20^{\circ} \mathrm{C}$. Anti-3AcDON titers were determined in the sera using the indirect non-competitive ELISA described below.

\section{Preparation of Coating Antigens}

Covalent coupling of 3-AcDON to OVA via a hemiglutarate bridge (Figure 4, B2 to D2). The 3-AcDON-hemiglutarate derivative (3-AcDON-HG, B2) was synthesized in a manner similar to that described for the 3-AcDON-HS except glutaric anhydride instead of succinic anhydride was used (Usleber et al, 1991). The derivative was then conjugated to OVA using the CDI method (Colburn, 1975; Kierek-Jaszczuk et al, 1995 and Stabb, 1962) with modifications; $4.4 \mathrm{mg}$ of 3-AcDON-HS and $2.5 \mathrm{mg}$ of CDI were dissolved in $250 \mu \mathrm{l}$ dimethylformamide (DMF). OVA (45 mg) was dissolved in $2.5 \mathrm{ml}$ of $0.05 \mathrm{M}$ boric acid-borax buffer ( $\mathrm{pH} 9.2$ ). The solution with activated toxin was added dropwise to the aqueous protein solution while stirring. The mixture was allowed to react for $2 \mathrm{hr}$ at room temperature and the conjugate, 3-AcDON-HG-OVA (D2), was purified and stored as described for the immunogen. 


\section{Conjugation of 3-AcDON to HSA and OVA via an O-methylcarboxyl bridge}

(Figure 4. B3 to D3h and D3o). The hydroxyl group at the C-15 position of 3-AcDON molecule was converted to a carboxyl group by the carboxymethylation method (Inman, 1975 and Xiao et al, 1995). Briefly, $3.4 \mathrm{mg}$ of toxin and $2.0 \mathrm{mg}$ of iodoacetic acid were dissolved in $1.5 \mathrm{ml}$ chloroform containing an excess of active solid sodium. The reaction mixture was kept in the dark at room temperature for $18 \mathrm{hr}$ followed by drying under $\mathrm{N}_{2}$ and redissolving in $5 \mathrm{ml}$ chloroform. After washing three times, each with $20 \mathrm{ml}$ of 0.1 $\mathrm{N} \mathrm{HCl}$, the organic phase was evaporated under $\mathrm{N}_{2}$ followed by further drying in a vacuum rotary evaporator (Savant AS-160, Savant Instruments Inc. Farmingdale, NY, USA). The unmodified 3-AcDON and the reaction product, 15-(O-1-carboxylmethyl)-3AcDON (3-AcDON-MC, Figure 4. B3) were then subjected to normal phase (silica) TLC in a solvent system consisting of toluene, ethyl acetate and fumaric acid mixed in the ratio of $6: 3: 1(\mathrm{v} / \mathrm{v} / \mathrm{v})$. After chromatography, the plate was sprayed with $p$ anisaldhyde followed by heating at $130^{\circ} \mathrm{C}$ for $8-10$ min. Each compound migrated as a single spot with the Rf values being 0.38 and 0.45 for $3-A c D O N$ and $3-A c D O N-M C$, respectively. The structure of the carboxymethylated derivative was further characterised by ${ }^{1} \mathrm{H}$ nuclear magnetic resonance $\left({ }^{1} \mathrm{H}\right.$ NMR, Bruker, AM-300, Department of Chemistry, University of Manitoba) and the presence of an additional single peak at $83.55 \mathrm{ppm}, 1.8 \mathrm{H}\left(-\mathrm{CH}_{2} \mathrm{COOH}-\right)$ was confirmed. $3-\mathrm{AcDON}-\mathrm{MC}$ was then conjugated to HSA and OVA by the CDI method as described above using a toxin to protein molar ratio of 20:1.

Conjugation of 3-AcDON to OVA via an (O-carboxymethyl)oxime bridge (Figure 
4. B4 to D4). A carboxyl group was introduced into 3-AcDON in place of the carbonyl group at the C-8 position using an oximation reaction (Bayard et al, 1970 and Erlanger et al, 1959) modified in a following way: $4.3 \mathrm{mg}$ of carboxymethoxylamine hemihydrochloride were dissolved in $100 \mu \mathrm{l}$ of $1 \mathrm{M}$ sodium carbonate and $900 \mu 1$ of methanol containing $3.4 \mathrm{mg}$ of 3-AcDON were added. The reaction mixture was carried out at $65^{\circ} \mathrm{C}$ for $5 \mathrm{hr}$ and then cooled on ice. Five milliliters of $0.1 \mathrm{~N} \mathrm{HCl}$ were then added and the reaction product, 3-AcDON-8-(O-carboxymethyl)oxime (3-AcDON-CMO, B4), was extracted with $10 \mathrm{ml}$ ethyl acetate. The extract was dried and the derivative was tested by TLC using the conditions described above. The Rf value of the derivative was 0.42 . The identity of the derivative was further confirmed using mass spectrometry with the $\mathrm{m} / \mathrm{z}$ being 411 (EI-MS, VG 7070E-HF, University of Manitoba Mass Spectrometry Center). This derivative was conjugated to OVA by the CDI method using a molar ratio of OVA to toxin of 20:1. The protein content of each conjugate was determined by the Bradford method (Bradford, 1976).

\section{Preparation of Acetylated Deoxynivalenol (AcDON) and Nivalenol (AcNIV)}

Deoxynivalenol was subjected to acetylation (Xu et al, 1988) with modifications. In brief, $2 \mathrm{mg}$ of DON dissolved in $0.4 \mathrm{ml}$ acetonitrile were reacted with $50 \mu \mathrm{l}$ acetic anhydride and $100 \mu \mathrm{l} 1$-methylimidazole in a water bath at $65^{\circ} \mathrm{C}$ for $30 \mathrm{~min}$. After washing with distilled water, the product was extracted with $5 \mathrm{ml}$ chloroform and evaporated to dryness. The dry residue was redissolved in $1 \mathrm{ml}$ methanol. The extent 
of the reaction were assessed by TLC and the acetylated product was used in the competitive ELISA. Acetylation of nivalenol was performed using the same procedure.

\section{Indirect ELISA}

Non-competitive and competitive antibody capture ELISAs were performed as outlined by Harlow and Lane (1988). The microtiter plates were coated with different coating conjugates: 3-AcDON-HG-OVA (D2), 3-AcDON-MC-OVA (D3o), 3-AcDONMC-HSA (D3h) or 3-AcDON-CMO-OVA (D4) at various concentrations as indicated in each experiment. The conjugates were dissolved in $0.05 \mathrm{M}$ carbonate-bicarbonate buffer (pH 9.6) and $100 \mu \mathrm{l}$ were added to each well of the plates. The plates were incubated at $37^{\circ} \mathrm{C}$ for $2 \mathrm{hr}$ followed by washing three times in PBST buffer, i.e., PBS buffer containing $0.05 \%(\mathrm{v} / \mathrm{v})$ Tween-20. They were then blocked at $37^{\circ} \mathrm{C}$ for $2 \mathrm{hr}$ with $4 \%$ (w/v) skim milk dissolved in PBS buffer to cover the free binding sites that remained on the plates. After blocking, the plates were washed three times with PBST buffer and dried. The coated and blocked plates could be stored with covers at $-20^{\circ} \mathrm{C}$ for several weeks until used. For the non-competitive ELISA, rabbit antisera were subjected to three-fold serial dilutions in dilution buffer, i.e., PBS buffer with $1 \%(w / v)$ skim milk solution. Each antibody dilution was added to the plates $(100 \mu 1 /$ well) in triplicates and incubated at $37^{\circ} \mathrm{C}$ for $1 \mathrm{hr}$. For the competitive ELISA, $45 \mu \mathrm{l}$ of PBS and $5 \mu \mathrm{l}$ of toxin standards prepared in methanol together with $50 \mu \mathrm{l}$ of an optimal dilution of selected antiserum were mixed to yield final toxin concentrations ranging from 0 to $5 \mu \mathrm{g} / \mathrm{ml}$. The 
mixtures were preincubated at $4^{\circ} \mathrm{C}$ overnight followed by adding to the pre-coated plate $\left(100 \mu \mathrm{l} /\right.$ well) and reacted at $37^{\circ} \mathrm{C}$ for $1 \mathrm{hr}$. For both assays, after the washing and drying steps, $100 \mu 1$ of alkaline phosphatase conjugated anti-rabbit IgG diluted 1:5,000 in dilution buffer were added to all wells and incubated at $37^{\circ} \mathrm{C}$ for $2 \mathrm{hr}$. After the plates were washed extensively and emptied, enzyme substrate was added. The substrate, $p$ NPP, was dissolved in diethanolamine (DEA) buffer $(10 \% \mathrm{v} / \mathrm{v}$ DEA and 1 $\mathrm{mM} \mathrm{MgCl}_{2}, \mathrm{pH} 9.8$ ) to yield a concentration of $1 \mathrm{mg} / \mathrm{ml}$ and $100 \mu \mathrm{l}$ of this substrate solution was applied to each well. The plate was incubated at $37^{\circ} \mathrm{C}$ for $30-40 \mathrm{~min}$. This yielded an absorbance at $405 \mathrm{~nm}$ of 1.2-1.5, except for the plate coated with 3-AcDONCMO-OVA (D4). The absorbance was read on Bio-Rad Model 450 microplate Reader (Bio-Rad, Fort Richmond, CA, USA). The antibody titers were defined as the reciprocal dilutions of antisera corresponding to 0.4 absorbance units at $405 \mathrm{~nm}$. The results of the competitive ELISAs were expressed as inhibition curves by plotting toxin concentrations $(\mathrm{ng} / \mathrm{ml})$ against the relative absorbance $\left(\% \mathrm{~B} / \mathrm{B}_{0}\right)$ using a graphic plotting program (Fig.P Software Co., Durham, NC and Biosoft, Miltown, NY, USA). The equation for the standard curve was obtained by fitting the data to a four-parameter logistic equation (Kierek-Jaszczuk et al, 1995; Rodbard and McClean 1977). The sensitivity $\left(\mathrm{IC}_{50}\right)$ of the assay was defined as the toxin concentration which caused a $50 \%$ decrease in maximal absorbance. The $\mathrm{IC}_{50}$ was determined by the indirect competitive ELISA on plates coated with $10 \mu \mathrm{g} / \mathrm{ml}$ of 3-AcDON-MC-OVA using anti-3-AcDON antiserum at a dilution of $1: 6,000$. The detection limit for the toxin was defined as the toxin concentration which caused a decrease in absorbance that was equal to two standard deviations (SD) as 
calculated from maximal absorbance value. The three-dimensional molecular images were obtained using PCMODEL from Molecular Modeling Software (Serena Software, Bloomington, IN, USA).

\section{Quantitation of 3-AcDON in Toxin Spiked Barley}

Barley $(1 \mathrm{~kg})$ was ground in a Cyclotec mill (Tecator AB, Höganäs, Sweden) and passed through a $1 \mathrm{~mm}$ screen. The toxin, 3-AcDON, was dissolved in methanol at concentrations of $10,2.5,0.625,0.156,0.078,0.039$ and $0 \mu \mathrm{g} / \mathrm{ml}$ and $100 \mathrm{~g}$ aliquots of barley were spiked with $10 \mathrm{ml}$ of each solution to yield final concentrations of 1000 , $250,62.5,15.6,7.8,3.9$ and $0 \mathrm{ppb}(\mathrm{ng} / \mathrm{g})$, respectively. After extensive mixing and drying, $4 \mathrm{~g}$ of each sample was mixed with $20 \mathrm{ml}$ of two extraction solvent systems: 84:16 (v/v) acetonitrile and water containing 4\% KCl (solvent a, Barna-Vetró et al 1994 and Trucksess et al 1984); 2) 70:30 (v/v) methanol and water (solvent b) followed by vigorous shaking for $30 \mathrm{~min}$ at room temperature. After centrifugation $(10,000 \mathrm{~g}, 15$ $\min , 4^{\circ} \mathrm{C}$ ), the supernatant was collected and assayed using the indirect competitive ELISA. It was performed on plates coated with $10 \mu \mathrm{g} / \mathrm{ml}$ of 3-AcDON-MC-OVA using anti-3-AcDON antiserum at a dilution of 1:6,000. In the comparative studies, three standards of each solvent system were conducted as followed: 1) normal standard condition: each well contained $45 \mu 1$ of PBS, $5 \mu 1$ of standard diluted 3-AcDON in either acetonitrile or methanol and $50 \mu \mathrm{l}$ of antiserum; 2) addition solvent condition: each well contained $40 \mu \mathrm{l}$ of PBS, $5 \mu \mathrm{l}$ standard diluted toxin in either acetonitrile or methanol, 5 
$\mu \mathrm{l}$ of solvent $\mathrm{a}$ or $\mathrm{b}$ and $50 \mu \mathrm{l}$ of antiserum; 3) matrix condition: each well contained 40 $\mu \mathrm{l}$ of PBS, $5 \mu \mathrm{l}$ of standard diluted toxin in either acetonitrile or methanol, $5 \mu 1$ of extract from toxin-free barley using solvent $a$ or $b$. In the quantification assays, each well contained $40 \mu \mathrm{l}$ of PBS, $5 \mu 1$ of acetonitrile or methanol, $5 \mu \mathrm{l}$ of the extract from barley that was spiked with the toxin and $50 \mu \mathrm{l}$ of antiserum. The reference standards were coassayed at the same time with each well containing $40 \mu \mathrm{l}$ of PBS, $5 \mu 1$ of the 3-AcDON standards prepared in either acetonitrile or methanol, $5 \mu 1$ of extract from the toxin-free barley sample and $50 \mu \mathrm{l}$ of antiserum.

\section{Direct ELISA}

The direct competitive antigen capture ELISA for quantification of 3-AcDON was performed as follows: recombinant protein $\mathrm{G}(10 \mu \mathrm{g} / \mathrm{ml})$ was precoated onto microtiter plates $(100 \mu 1 /$ well $)$ at left at room temperature overnight. The plates were then washed three times with PBST buffer. One hundred microliter rabbit anti-3-AcDON-HS-HSA antiserum diluted 1:400 in PBS was then added to each well and incubated at $37^{\circ} \mathrm{C}$ for $2 \mathrm{hr}$ followed by washing three times with PBST buffer and air drying. Fifty microliter of 3-AcDON-HRP conjugate together with $45 \mu$ l of PBS containing $1 \%$ BSA and $5 \mu 1$ of toxin standards prepared in methanol were added to each well. The mixture were incubated at $37^{\circ} \mathrm{C}$ for $1 \mathrm{hr}$ followed by washing six times with PBST buffer and air drying. OPD substrate solution was add (100 $\mu 1 /$ well). After $20 \mathrm{~min}$, the reaction was stopped with $0.3 \mathrm{M}$ sulphuric acid and absorbance at $490 \mathrm{~nm}$ was measured. The 
standard curve was plotted in the same manner as in the indirect competitive assay. 


\section{RESULTS}

Antibody responses were detected in the sera of all immunized rabbits and chickens five weeks after the initial injection. High serum titers (greater than 100,000 ) were observed at week nine of immunization whereby preimmunized sera of the same animals were negative in the non-competitive ELISA when 3-AcDON-HG-OVA was used as the coating antigen. Antibody titers were lower when 3-AcDON-CM-OVA was used as the coating antigen. Figure 5 (a and b) showed a typical anti-3-AcDON antibody response in one of the four rabbits and one of the chickens that were immunized with the 3-AcDON-HS-HSA conjugate. The serum with highest titer and sufficient quantity was used for immunoassay development.

The optimal concentrations of the coating antigens and dilutions of antisera were determined using a checkerboard titration test. Figure 6(a and b) demonstrated that the indirect competitive ELISA showed different absorbance (a) and sensitivities (b) when varying amount of coating antigen 3-ACDON-MC-OVA were immobilized on the plate. Although the smaller amount of coating antigen showed the better sensitivity, the absorbance of the color reaction was lower. The effect of antibody dilution on the sensitivity of the assay were also studied (Figure 7, a and b). The inhibition curve obtained with more diluted antibodies resulted in a slightly better sensitivity but yielded lower absorbance values. Consequently, the optimal conditions for the indirect competitive ELISAs as determined in these studies were used in further assay 
Figure 5 Typical production of polyclonal antibodies against 3-acetyldeoxynivalenol (3-AcDON) in rabbits (5a) and chickens (5b).

Four Dutch-belted rabbits and four white Leghorn laying hens were immunized with 3-AcDON-HS-HSA. Booster injection were given at 5-6 week intervals. The result represent typical titers in the serum of a rabbit and a chicken as determined by indirect non-competitive ELISA using 3AcDON-CM-OVA $(10 \mu \mathrm{g} / \mathrm{ml})$ as the coating antigen. The arrows indicate the time of each immunizing and boosting injection. The $y$-axis gives the reciprocal of antisera dilutions. 


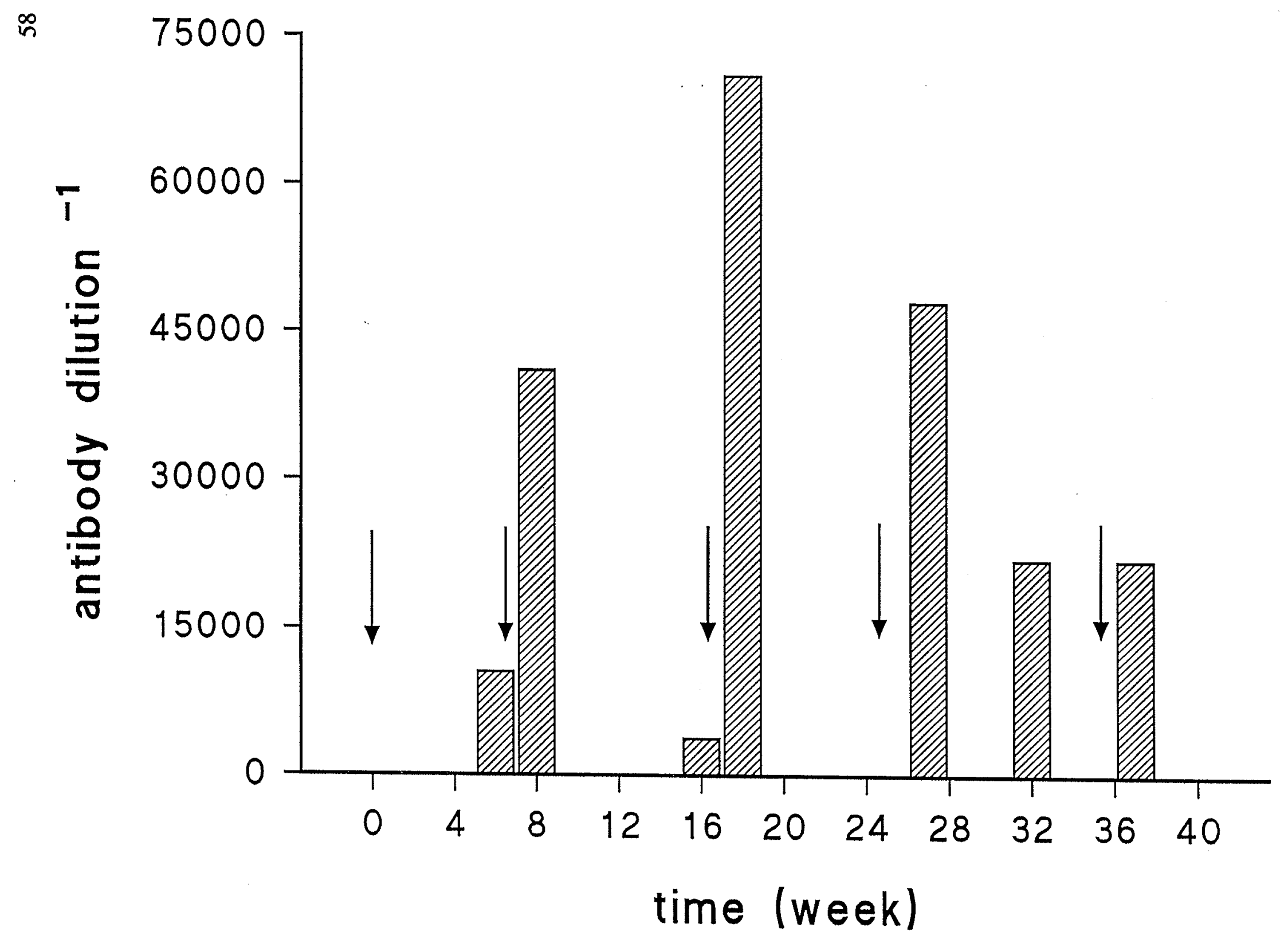




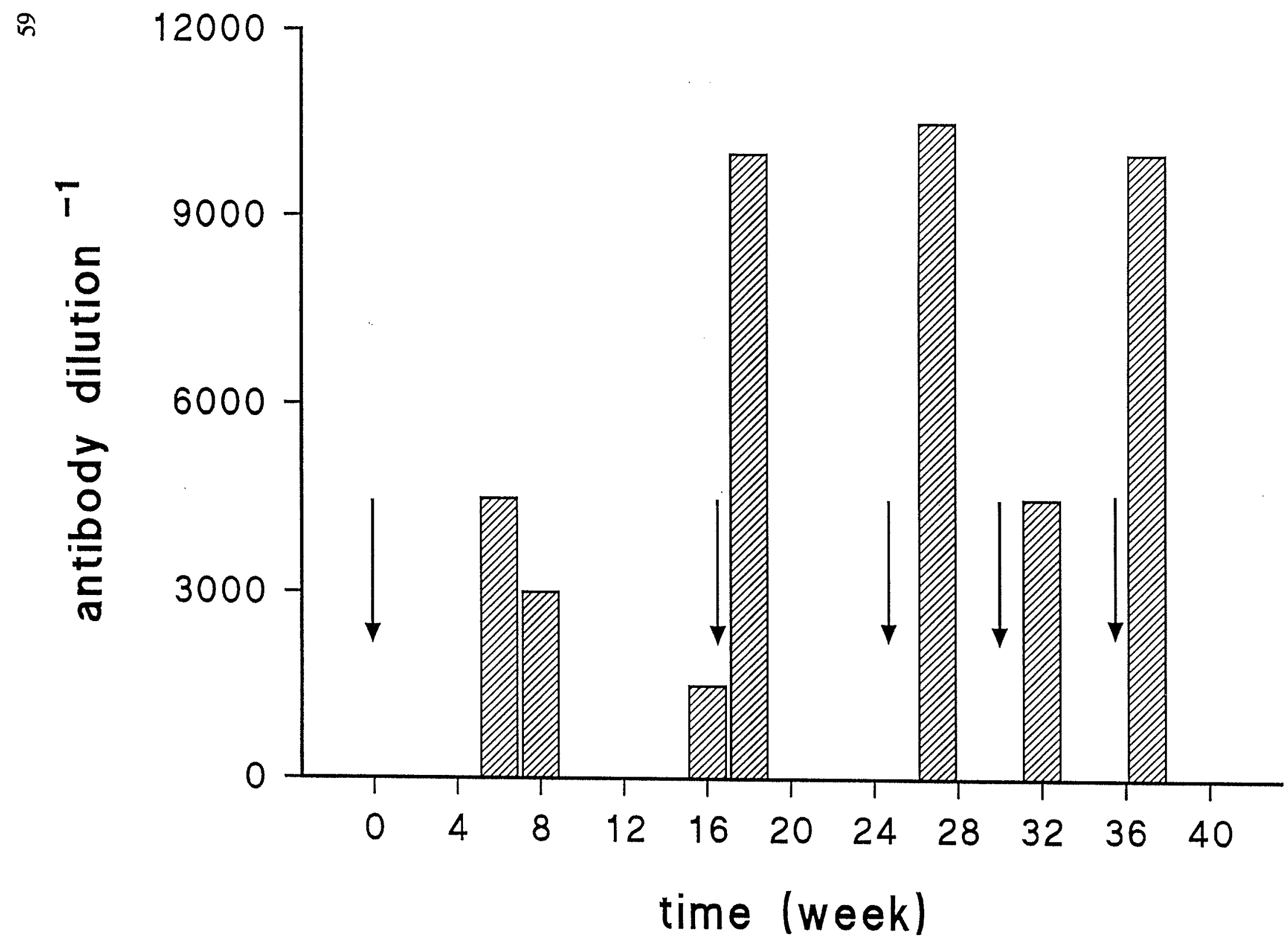

$5 b$ 
Figure 6. The effects of plate coating antigen concentration on the performance of the indirect competitive ELISA.

The microtiter plate was coated with 3-AcDON-CM-OVA in concentrations of $5 \mu \mathrm{g} / \mathrm{ml}(\bullet \cdots \bullet) ; 10 \mu \mathrm{g} / \mathrm{ml}(\mathbf{\Lambda} \longrightarrow)$ ) and $25 \mu \mathrm{g} / \mathrm{ml}$ (1- The results are expressed as absorbance (6a) and relative maximum absorbance (6b). Each data represents the mean of the four replicates $\pm S D$. 


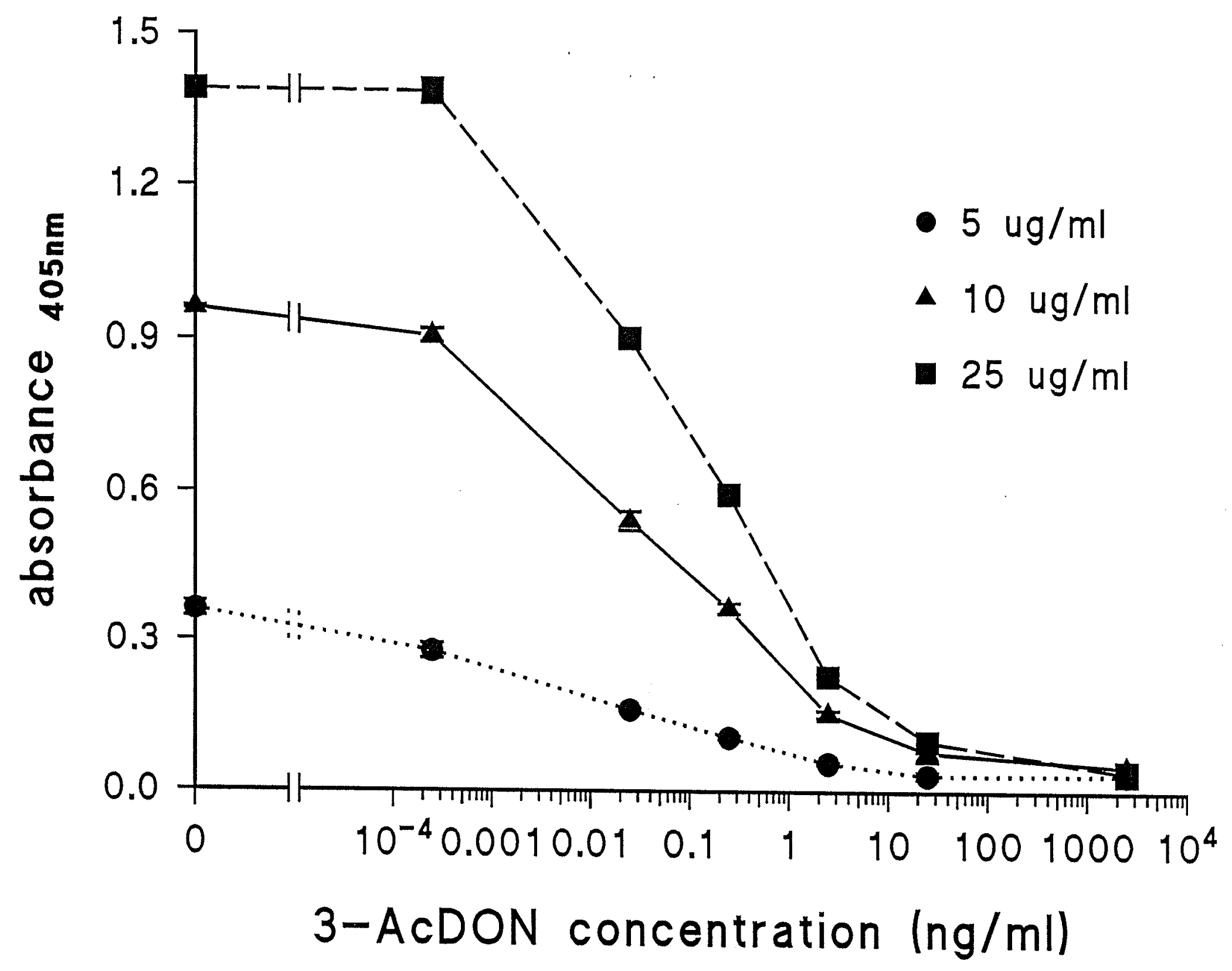




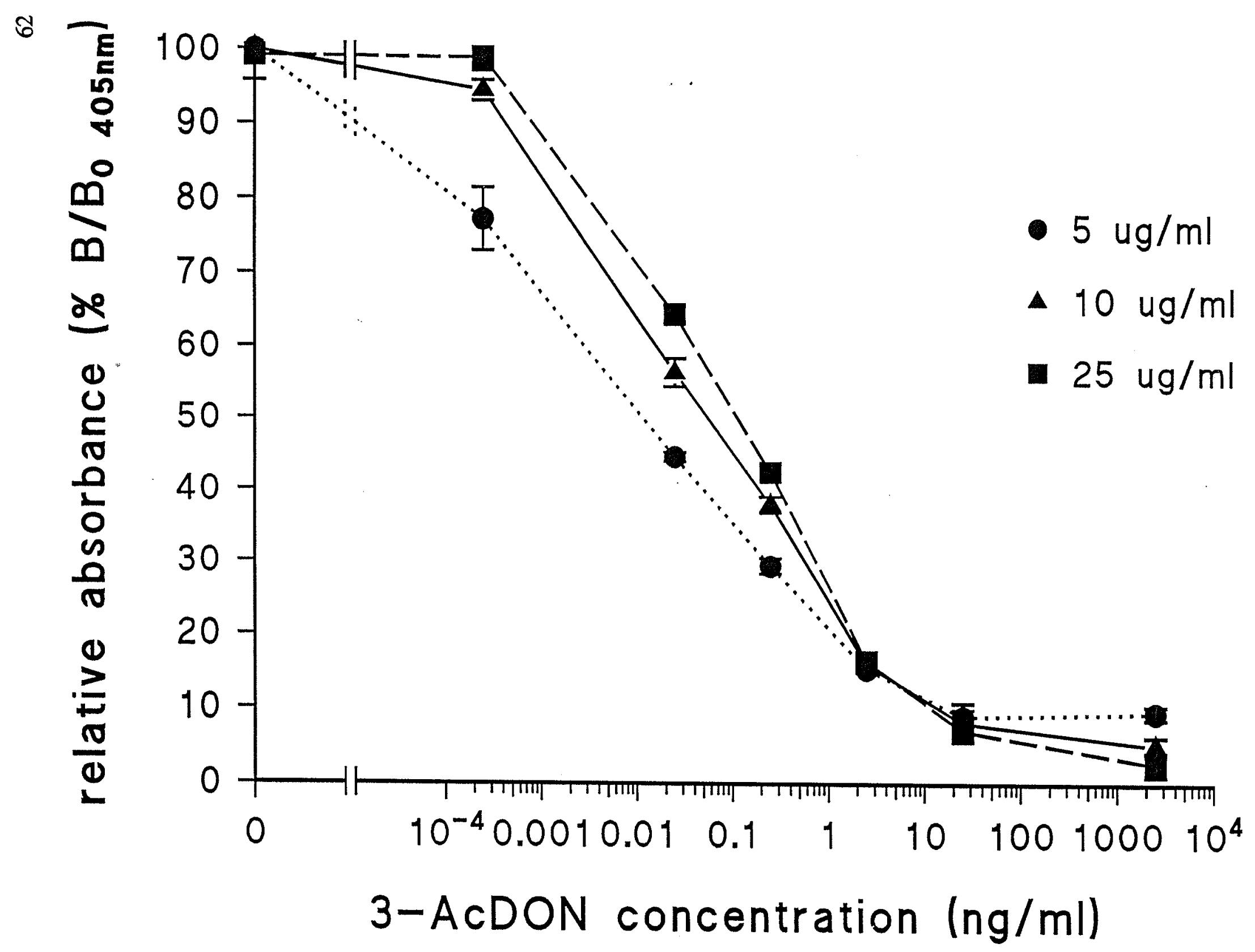


Figure 7. The effects of antibody concentration on the performance of the indirect competitive ELISA.

The microtiter plate was coated with 3-AcDON-CM-OVA $(10 \mu \mathrm{g} / \mathrm{ml})$. Rabbit anti-3Ac-DON antisera were used in 1: 2,000 (घ-口); $1: 6,000$ $(\Delta-\Delta)$ and 1: 10,000 ( $(\bullet \bullet)$ dilutions. Results are expressed as absorbance (7a) and relative maximum absorbance (7b). Each data represents the mean of the four replicates $\pm S D$. 


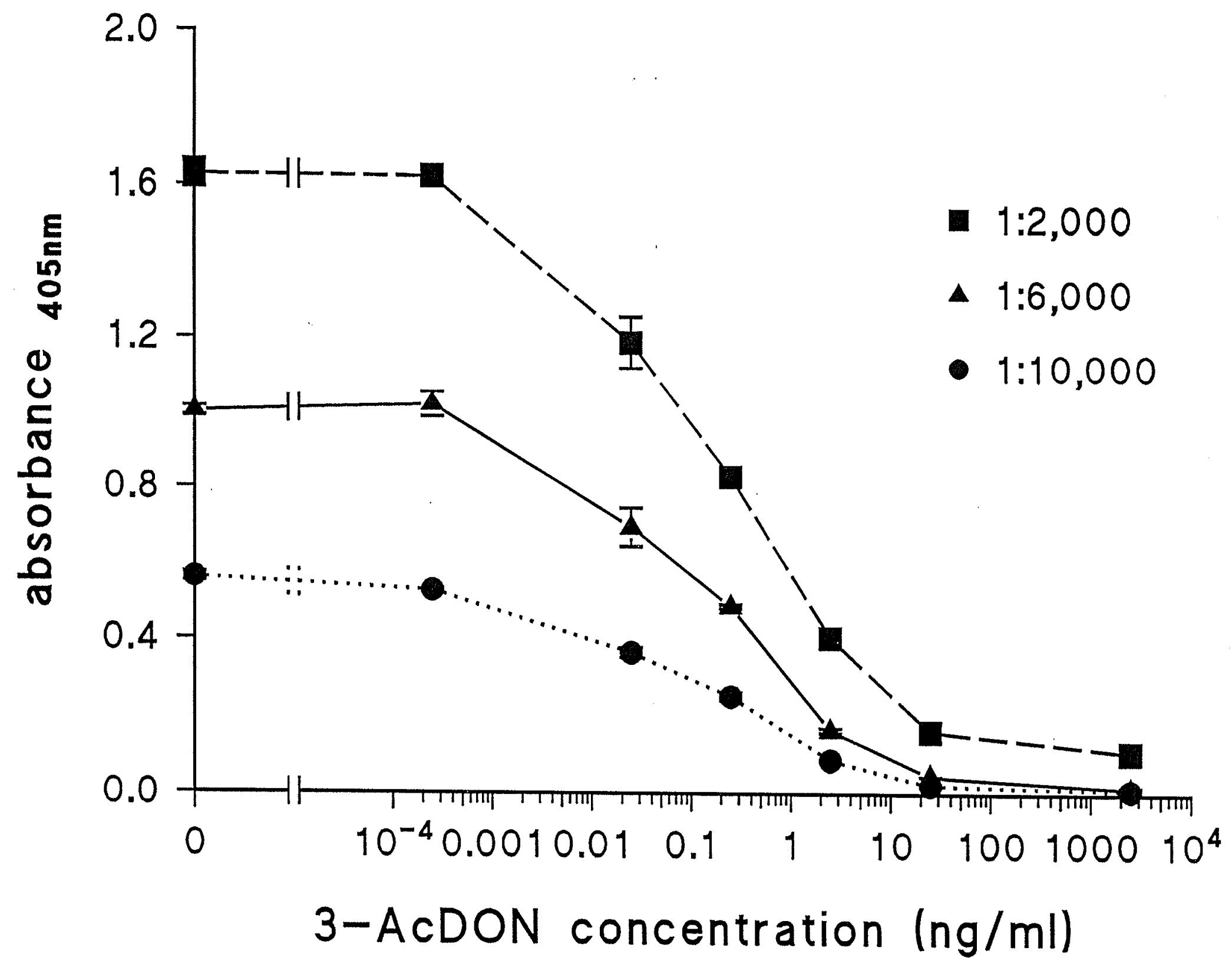




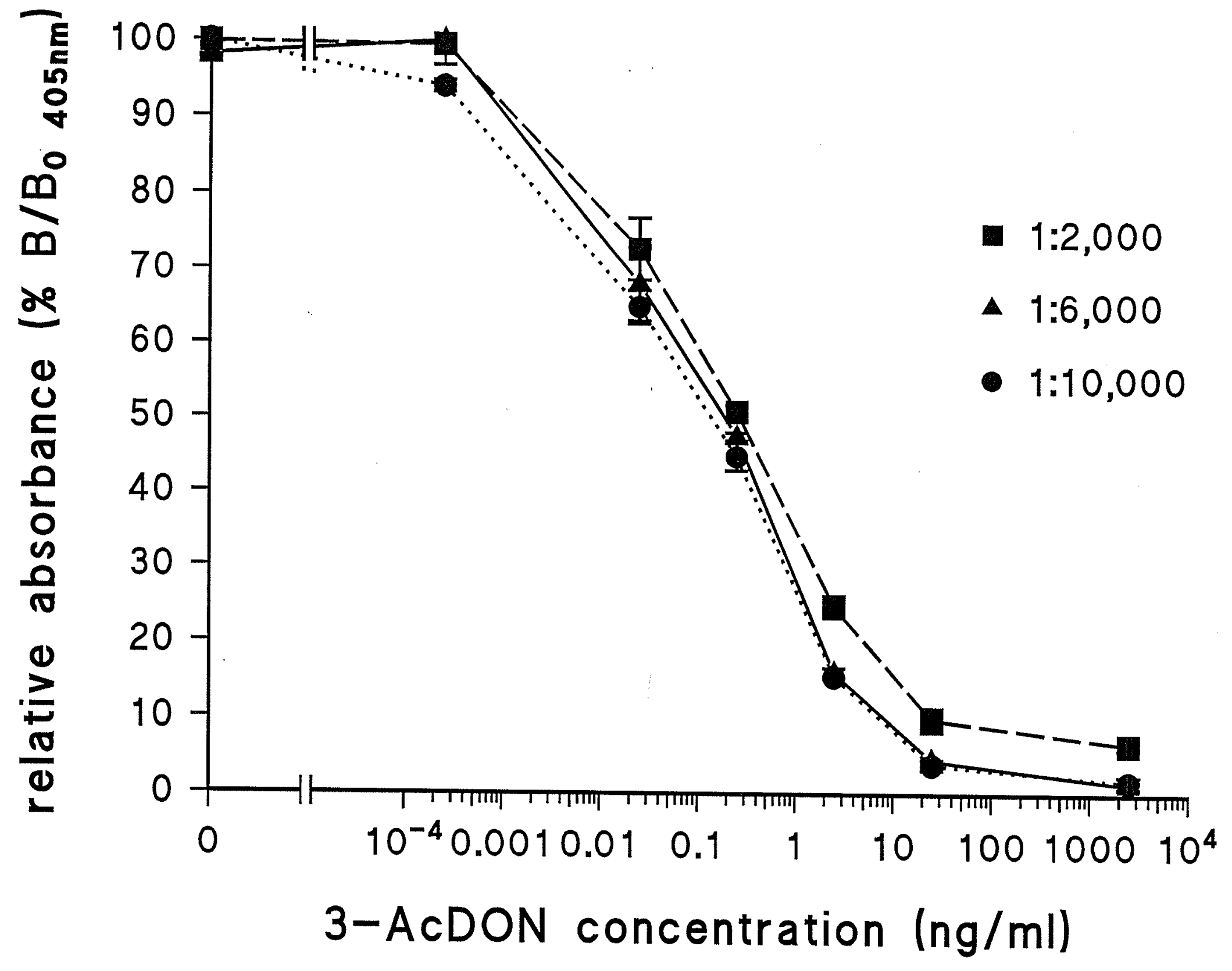


development. The concentrations of the coating conjugates 3-AcDON-HG-OVA (D2), 3-AcDON-MC-HSA (D3h), 3-AcDON-MC-OVA (D3o) and 3-AcDON-CMO-OVA (D4) were $5,10,10,25 \mu \mathrm{g} / \mathrm{ml}$, with the corresponding dilutions of antiserum being $1: 80,000$, $6,000,6,000$ and 800 , respectively.

Although the antisera with high titers indicated the presence of specific anti-3AcDON antibodies, initial competitive ELISA experiments were not successful when 3AcDON-HG-OVA was used as the coating antigen (Figure 8, D2). Pretreatment of antisera with a $0.5 \%(\mathrm{w} / \mathrm{v})$ heat-denatured HSA solution to absorb the anti-carrier antibody population was not effective. Subsequently, competitive ELISAs were performed using coating antigens that had the following characteristics in respect to the immunogen (Figure 4): (i) a homologous linkage conjugate (3-AcDON-HG-OVA, D2) containing the same linkage site (C-15) and the same ester linkage but a different bridge length (hemiglutarate instead of hemisuccinate) and a different protein carrier; (ii) heterologous linkage conjugates (3-AcDON-MC-HSA, D3h and 3-AcDON-MC-OVA, D3o) containing the same linkage site (C-15), a different linkage group (methylcarboxyl bridge) and either the same or a different protein carrier and (iii) a heterologous linkage and heterologous site conjugate (3-AcDON-OXM-OVA, D4) containing a different coupling site (C-8), a different linkage (carboxymethyloxime bridge) and a different carrier.

The results plotted in Figure 8 demonstrated that the sensitivities and noninhibitable background of the competitive assays were markedly influenced by the nature of the coating conjugates. For example, the maximum inhibition was 24 and $65 \%$ when 
Figure 8. Effect of different coating conjugates on the sensitivity and non-inhibitable background of the competitive ELISA using 3-acetyldeoxynivalenol (3AcDON) as the competitor.

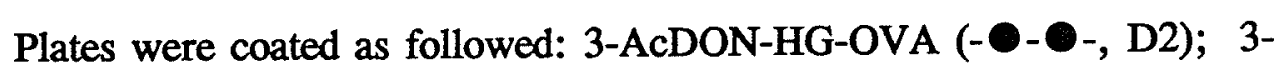
AcDON-MC-HSA (- $\square-\square-$, D3h); 3-AcDON-MC-OVA (-口-"-, D3o); 3-ACDON-OXM-OVA (-A-A-, D4). Each data is shown as the mean of the three replicate set of experiments \pm SD. See Figure 4 and Materials and Methods for further details of the conjugates. 


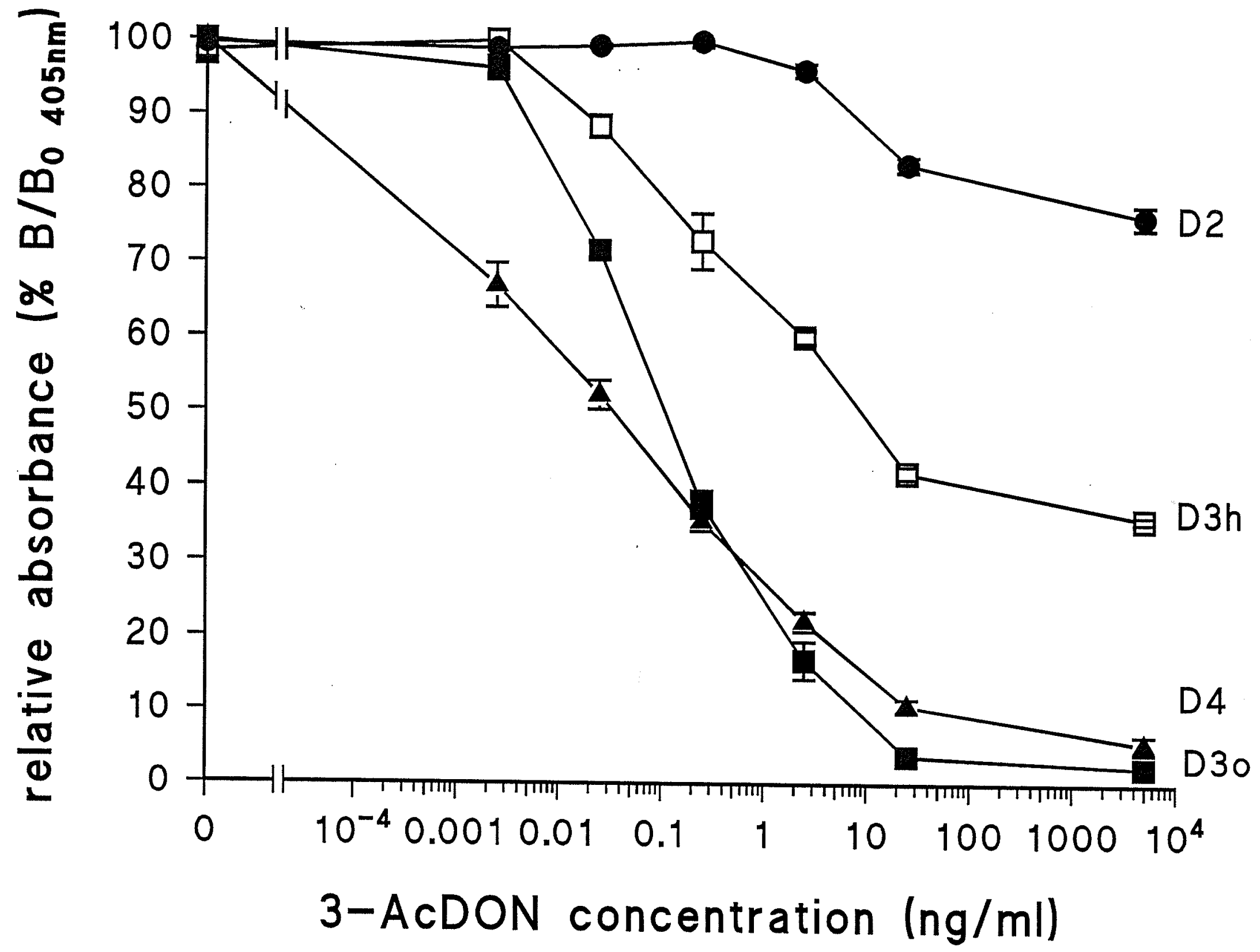


the plates were coated with 3-AcDON-HG-OVA (D2) or 3-AcDON-MC-HSA (D3h), respectively. Complete inhibition with the 3-ACDON, however, was achieved when the coating conjugate was 3-AcDON-MC-OVA (D3o), a conjugate that contained a heterologous protein and a heterologous linkage group. Using this system it was possible to quantitatively detect 3-AcDON in buffer solution at the nanogram level. In another heterologous system where the plates were coated with 3-AcDON-CMO-OVA (D4), a stronger inhibition response was observed than that seen with the previous conjugate (D3o), but there was not sufficient amount of antibody bound to the plate to give a strong signal in toxin-free solutions even when a high quantity of the antibody (1:800 dilution) and a high concentration of coating antigen $(25 \mu \mathrm{g} / \mathrm{ml})$ were used.

There was also a marked difference in the ability of 3-AcDON and two of its derivatives to compete with 3-ACDON-MC-OVA for the binding of the antibodies (Figure 9). The $\mathrm{IC}_{50}$ were $0.012,0.21$ and $110 \mathrm{ng} / \mathrm{ml}$ for 3-AcDON-HG (B2), 3AcDON (A) and 3-AcDON-CMO (B4), respectively. These results suggest that the binding of antibody to 3-AcDON-HG was 18 and 9000 times greater than that of 3AcDON and 3-AcDON-CMO and that 3-AcDON compared to 3-AcDON-HG-HSA competed weakly for the binding of antibody when the latter was used as the coating conjugate.

On the basis of these results, the heterologous conjugate, 3-AcDON-MC-OVA (D3o), at a concentration of $10 \mu \mathrm{g} / \mathrm{ml}$ was selected as the coating conjugate and the antibody was diluted 1:6,000 for subsequent assays as it provided an inhibition curve having a steep slope, minimal background interference (3\% of maximal absorbance) and 
Figure 9. Competition for antibody binding between free compounds: 3-AcDON (-

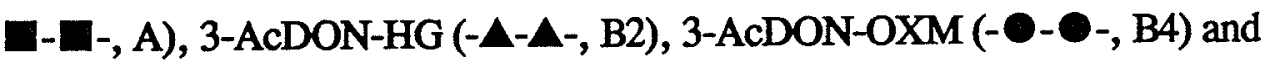
immobilized conjugate: 3-AcDON-MC-OVA $(10 \mu \mathrm{g} / \mathrm{ml})$ in the indirect competitive ELISA.

Anti-3-AcDON-HS-HSA rabbit antiserum was used at 1:6,000 dilution. Curve A is the typical inhibition curve for 3-AcDON. The detection limit and sensitivity of the assay are indicated by arrows. Each data represents the mean of triplicates sets of analytes \pm SD. See the Materials and Methods for further details and Figure 4. for structures. 


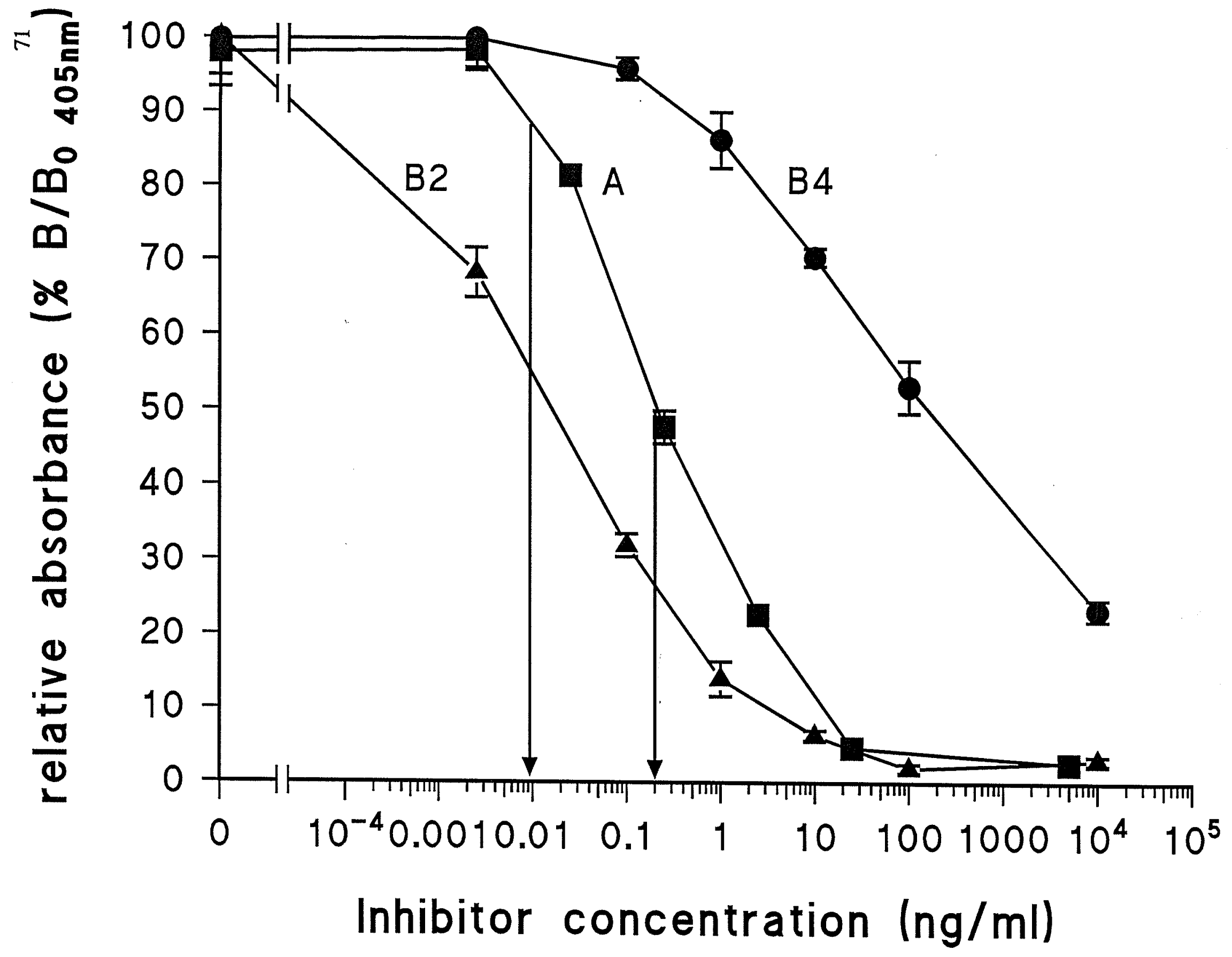


suitable time for color development (a maximum absorbance of 1.2-1.4 was obtained in $30 \mathrm{~min}$ at $37^{\circ} \mathrm{C}$ ). The assay had high sensitivity for $3-A c D O N$ with the $\mathrm{IC}_{50}$ being 0.21 $\mathrm{ng} / \mathrm{ml}$ and the detection limits being $0.01 \mathrm{ng} / \mathrm{ml}$. The standard inhibition curve was linear over a range of $3-A c D O N$ concentrations $(0.05$ to $10 \mathrm{ng} / \mathrm{ml})$ thereby allowing the quantitation of the toxin within this range (Figure 9, curve A).

The high specificity of the assay, which represents the ability of the test system to differentiate among structurally similar compounds, is illustrated by the low degree of cross-reactivity obtained with different DON analogs and most of the other trichothecenes (Table 6). The competitive ELISA using anti-3-AcDON antibodies had 4.6 and $0.01 \%$ cross-reactivity with $15-\mathrm{AcDON}$ and DON, respectively. No crossreactivities were obtained with any other trichothecenes except for two acetylated forms of the toxins, acetylated DON (907\%) and acetylated nivalenol (24.5\%). The result indicated that the antibody strongly recognized the C-3 acetyl side group of the 3-AcDON and that the $\mathrm{C}-8$ carbonyl moiety also played a role in this recognition. This assay system, therefore, can be considered to be highly specific for 3-AcDON detection with the exception of acetylated DON.

Comparative studies of three reference standards demonstrated that the presence of addition amount of acetonitrile (4.2\%) in the assay mixture reduced the absorbance values of the assay. A similar depression was observation in the presence or absence of the matrix suggesting the matrix had no effect on the inhibition reaction (Figure 10). To overcome the effect of acetonitrile, the standard solutions should contain the same concentration of acetonitrile as the analytes. In the methanol-water extraction system, 
Table 6. Reactivities of the Antiserum with 3-Acetyldeoxynivalenol (3-AcDON) and Other Related Trichothecenes

\begin{tabular}{lccc}
\hline \hline \multirow{1}{*}{ Trichothecenes } & \multicolumn{2}{c}{$\begin{array}{c}\text { Concentrations of toxins causing } 50 \% \\
\text { inhibition }\left(\mathrm{IC}_{50}\right)^{\mathrm{a}}\end{array}$} & Cross-reactivity $^{\mathrm{b}}$ \\
\cline { 2 - 4 } & $\mathrm{ng} / \mathrm{ml}$ & $\mathrm{nmol} / \mathrm{ml}$ & $(\%)$ \\
\hline \hline $\begin{array}{l}\text { 3-Acetyl } \\
\text { deoxynivalenol }\end{array}$ & 0.31 & $9.17 \times 10^{-4}$ & 100 \\
$\begin{array}{l}\text { Deoxynivalenol } \\
\begin{array}{l}\text { 15-Acetyl } \\
\text { deoxynivalenol }\end{array}\end{array}$ & 2500 & 8.45 & 0.01 \\
$\begin{array}{l}\text { Acetylated } \\
\text { deoxynivalenol }\end{array}$ & 6.67 & $1.98 \times 10^{-2}$ & 4.6 \\
$\begin{array}{l}\text { Acetylated } \\
\text { nivalenol }\end{array}$ & 0.04 & $1.0 \times 10^{-4}$ & 917 \\
Acetyl T-2 & 1.8 & $3.75 \times 10^{-3}$ & 24.5 \\
\hline \hline
\end{tabular}

a The $\mathrm{IC}_{50}$ was determined by an indirect competitive ELISA performed on plates coated with $10 \mu \mathrm{g} / \mathrm{ml}$ of 3-AcDON-MC-OVA using anti-3-AcDON antiserum at a dilution of $1: 6,000$.

b Cross-reactivity is defined as: $\mathrm{nmol} / \mathrm{ml}$ of $3-\mathrm{AcDON}$ causing $50 \%$ inhibition $/ \mathrm{nmol} / \mathrm{ml}$ of related toxin causing $50 \%$ inhibition $\times 100$. Other trichothecenes including nivalenol, fusarenon- $X$, neosolaniol, trichothecolone, diacetoxyscirpenol, $T-2$ tetraol tetraacetate and $\mathrm{T}-2$ did not inhibit the reaction at concentrations of $5 \mu \mathrm{g} / \mathrm{ml}$.

c The acetylated deoxynivalenol and nivalenol were prepared as described in Materials and Methods. The acetylated producted were monitored by TLC and were presumed as the triacetylated analogs. 
Figure 10. The effects of acetonitrile and extract from barley matrix on the standard curve of 3-AcDON as obtained with the indirect competitive ELISA. The microtiter plate was coated with 3-AcDON-CM-OVA $(10 \mu \mathrm{g} / \mathrm{ml})$ and rabbit anti-3AcDON antiserum $(1: 6,000)$ was used. The normal standard incubation mixture (1- contained $5 \mu$ l 3-AcDON standard in acetonitrile, $45 \mu \mathrm{l}$ of PBS, and $50 \mu \mathrm{l}$ of antibody dilution in PBS, which is equal to a final acetonitrile concentration of $5 \%$. The standard incubation mixture ( $\mathbf{\Delta}-\mathbf{A})$ contained $5 \mu$ l of toxin standard in acetonitrile, $40 \mu 1$ of PBS plus $5 \mu 1$ of solvent a (84\% acetonitrile) and $50 \mu 1$ of antibody dilution, which is equal to a final acetonitrile concentration of 9.2\% $(5+4.2 \%)$. The third standard incubation mixture $(\bullet \cdots)$ contained $5 \mu 1$ of toxin in acetonitrile, $40 \mu 1$ of PBS plus $5 \mu 1$ of toxin-free barley extract (containing $84 \%$ acetonitrile) and $50 \mu l$ of antibody dilution, which is equal to a final acetonitrile concentration of $9.2 \%(5+4.2 \%)$. Each data represents the mean of triplicate analyses. 


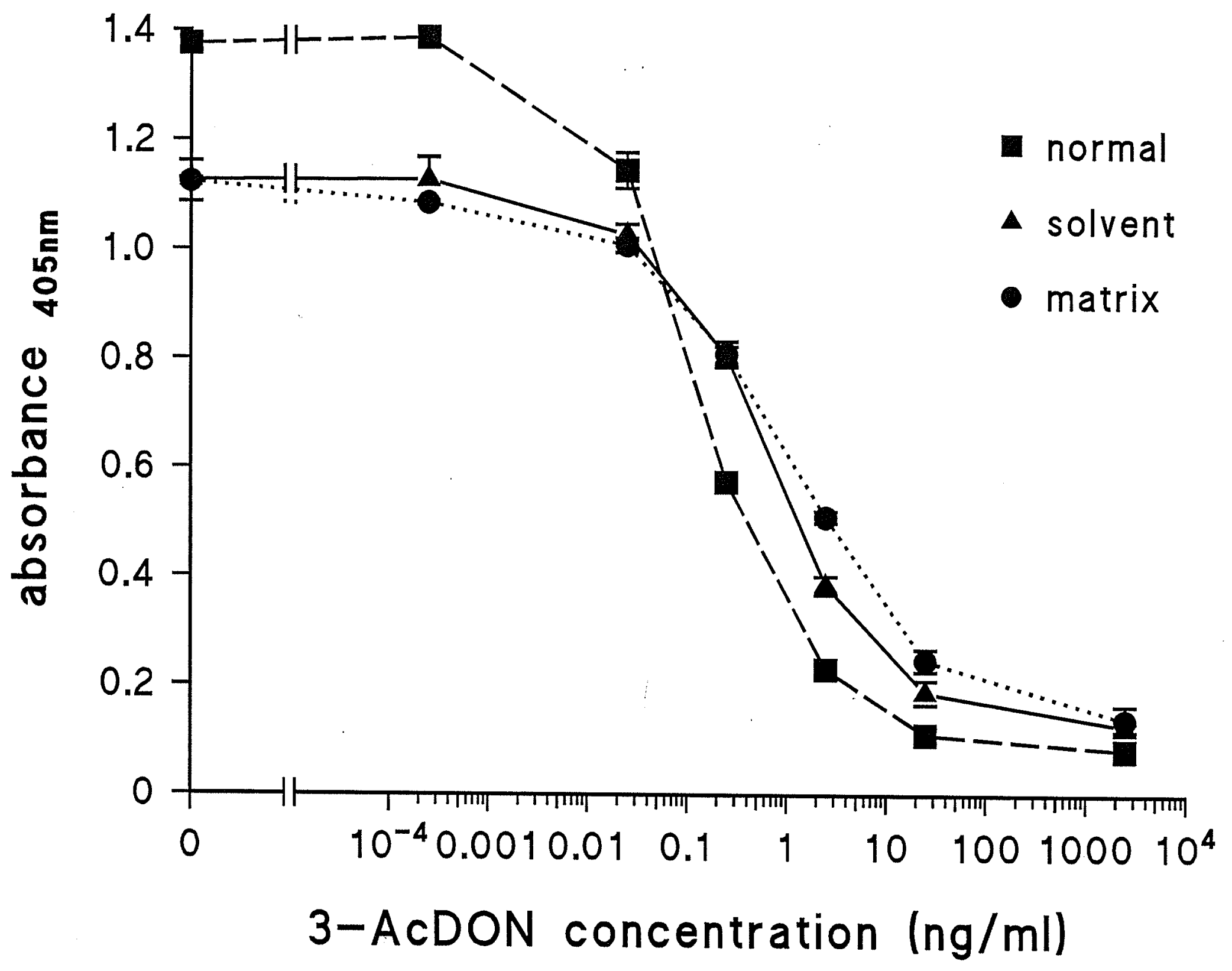


however, there was no apparent influence of amount of methanol when less than $10 \%$ of total concentration, while the incorporation of the barley extract into the standard preparation altered the assay performance (Figure 11). Therefore, when the grain matrix is extracted with methanol, the standard solutions should also contained the same amount of toxin-free barley extract. As a result, 3-AcDON was readily quantitated in barley with good recoveries without any clean-up or concentration treatments. The detection limit for 3-AcDON in spiked barley that was extracted with either acetonitrile or methanol was approximately $16 \mathrm{ppb}$ and the recovery of toxin was more than $83 \%$ at toxin concentrations ranging from 16 to $1000 \mathrm{ppb}$ (Table 7).

The standard curve for the direct competitive ELISA for 3-AcDON is shown in Figure 12. Rabbit anti-3-AcDON-HS-HSA was immobilized on the plate and 3-AcDON$\mathrm{HRP}$ conjugate was the enzyme marker. The $\mathrm{IC}_{50}$ of the assay was $1 \mathrm{ng} / \mathrm{ml}$ with almost no background interference being observed. 
Figure 11. The effects of methanol and extract from barley matrix on the standard curve of 3-AcDON as obtained with the indirect competitive ELISA. The microtiter plate was coated with 3-AcDON-CM-OVA $(10 \mu \mathrm{g} / \mathrm{ml})$ and rabbit anti-3AcDON antiserum $(1: 6,000)$ was used. The normal standard incubation mixture (- ${ }^{-}$) contained $5 \mu \mathrm{l}$ of 3-AcDON standard prepared in methanol, $45 \mu 1$ of PBS and $50 \mu 1$ antibody dilution in PBS, which is equal to a final methanol concentration of $5 \%$. The second standard incubation mixture ( $\Delta---\Delta)$ contained $5 \mu 1$ of toxin in methanol, $40 \mu 1$ of PBS plus $5 \mu 1$ of extract solvent b containing $70 \%$ methanol and $50 \mu 1$ of antibody dilution in PBS, which is equal to a final methanol concentration of $8.5 \%(5+3.5 \%)$. The third standard incubation mixture $(\bullet \cdots)$ contained $5 \mu \mathrm{l}$ of toxin in methanol, $40 \mu \mathrm{l}$ of PBS plus $5 \mu \mathrm{l}$ of toxin-free extract containing $70 \%$ methanol and $50 \mu 1$ of antibody in PBS, which is equal to a final methanol concentration of $8.5 \%(5+3.5 \%)$. Each data represents the mean of triplicate analysis. 


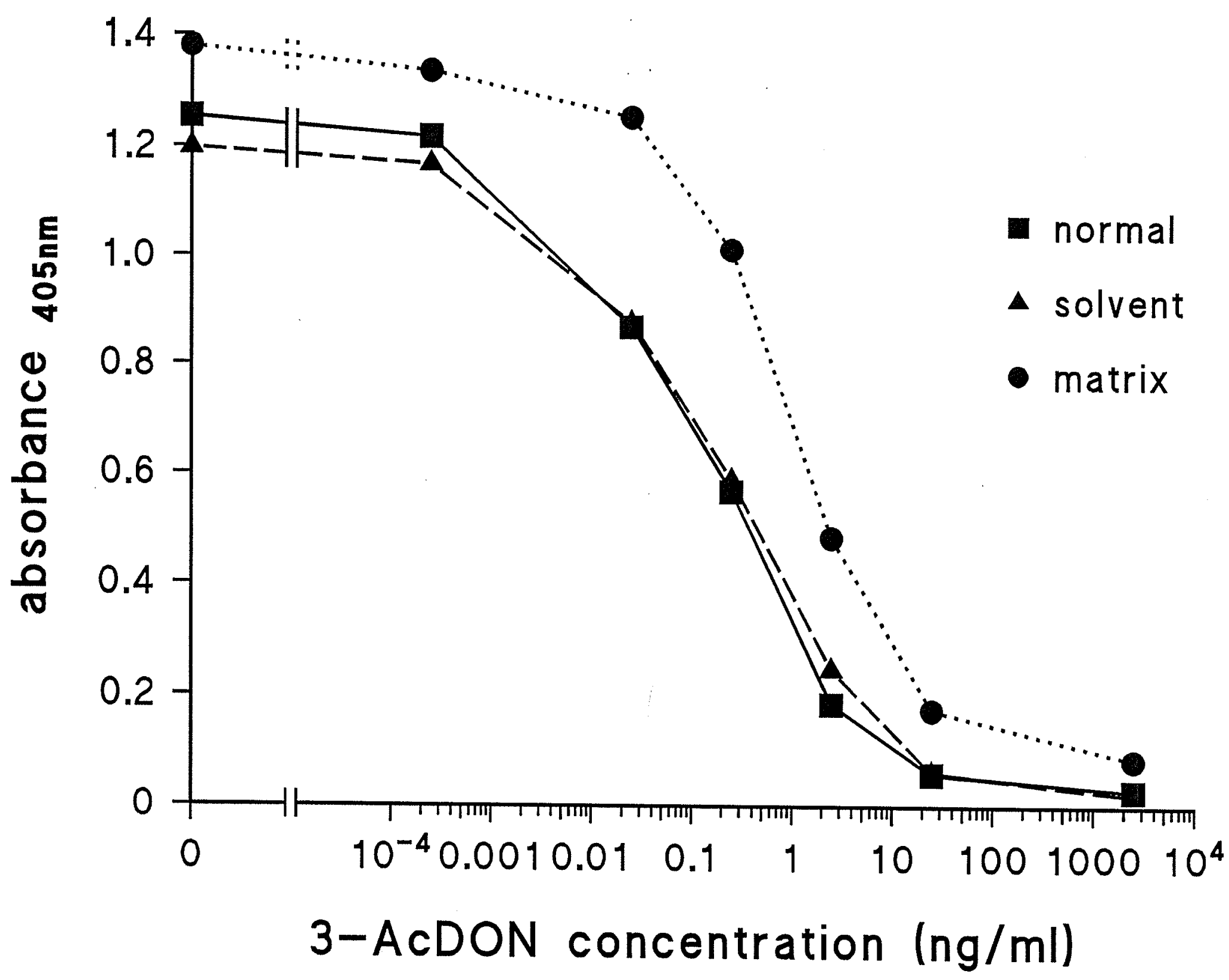


Table 7. Recovery of 3-AcDON from Spiked Barley Samples Using Acetonitrilewater (84:16) and Methanol-water (70:30) as Extraction Solvent.

\begin{tabular}{|c|c|c|c|}
\hline & $\begin{array}{l}\text { Toxin } \\
\text { added } \\
\text { (ppb; } \\
\mathrm{ng} / \mathrm{g} \text { ) }\end{array}$ & $\begin{array}{l}\text { Toxin detected }^{\mathbf{a}} \\
\text { (ppb; ng/g) }\end{array}$ & $\begin{array}{c}\text { Recovery } \\
(\%)\end{array}$ \\
\hline \multirow{6}{*}{ Acetonitrile } & 3.9 & $1.23 \pm 0.79$ & $31.5 \pm 20.2$ \\
\hline & 7.8 & $3.2 \pm 1.9$ & $41.2 \pm 24$ \\
\hline & 15.6 & 15.5 .1 .0 .8 & 99.8 .5 .5 .1$. \\
\hline & 62.4 & $63.1 .4: 4.4$ & 101.2 .1 .11 \\
\hline & 25040 & $4996 \cdot 1 \cdot 21.3$ & $87.9: 1.8 .5$ \\
\hline & 1000.0 & 836.9 .1 .120 .3 & $83.6 \pm 12.0$ \\
\hline \multirow{5}{*}{ Methanol } & 7.8 & $1.9 \pm 0.86$ & $24.4 \pm 45.2$ \\
\hline & 15.6 & $12.9+1.0 .78$ & $=82.7+6.0 .0$ \\
\hline & 62.4 & $=56.3+1.88$ & 90.21 .3 .2 \\
\hline & 250.0 & $2010.2+19.4$ & $84.1+9.9 .2$ \\
\hline & $1000 \%$ & $978.3+203.5$ & $97.8+21:$ \\
\hline
\end{tabular}

2 3-AcDON was detected by the indirect competitive ELISA performed on plates coated with $10 \mu \mathrm{g} / \mathrm{ml}$ of 3-AcDON-MC-OVA using anti-3-AcDON antiserum at a dilution of $1: 6,000$. Although the barley extract with no toxin did not affect the final absorbance value when acetonitrile was used as the extract solvent, toxin-free barley extract was incorporated into the standard to provide the same concentration of acetonitrile in the standard and in the samples. Each data is expressed as mean \pm SD and was obtained from three parallel experiments. In each experiment, sample extracts were assayed in triplicates. 
Figure 12. Typical standard curve for the detection of 3-AcDON using the direct antigen capture ELISA.

3-ACDON-HRP was used as the enzyme marker and rabbit antibodies obtained after immunization with 3-AcDON-HS-HSA were diluted 1:400 in PBS and immobilized on a microtiter plate precoated with protein G. Each data represents the mean of triplicates \pm SD. 


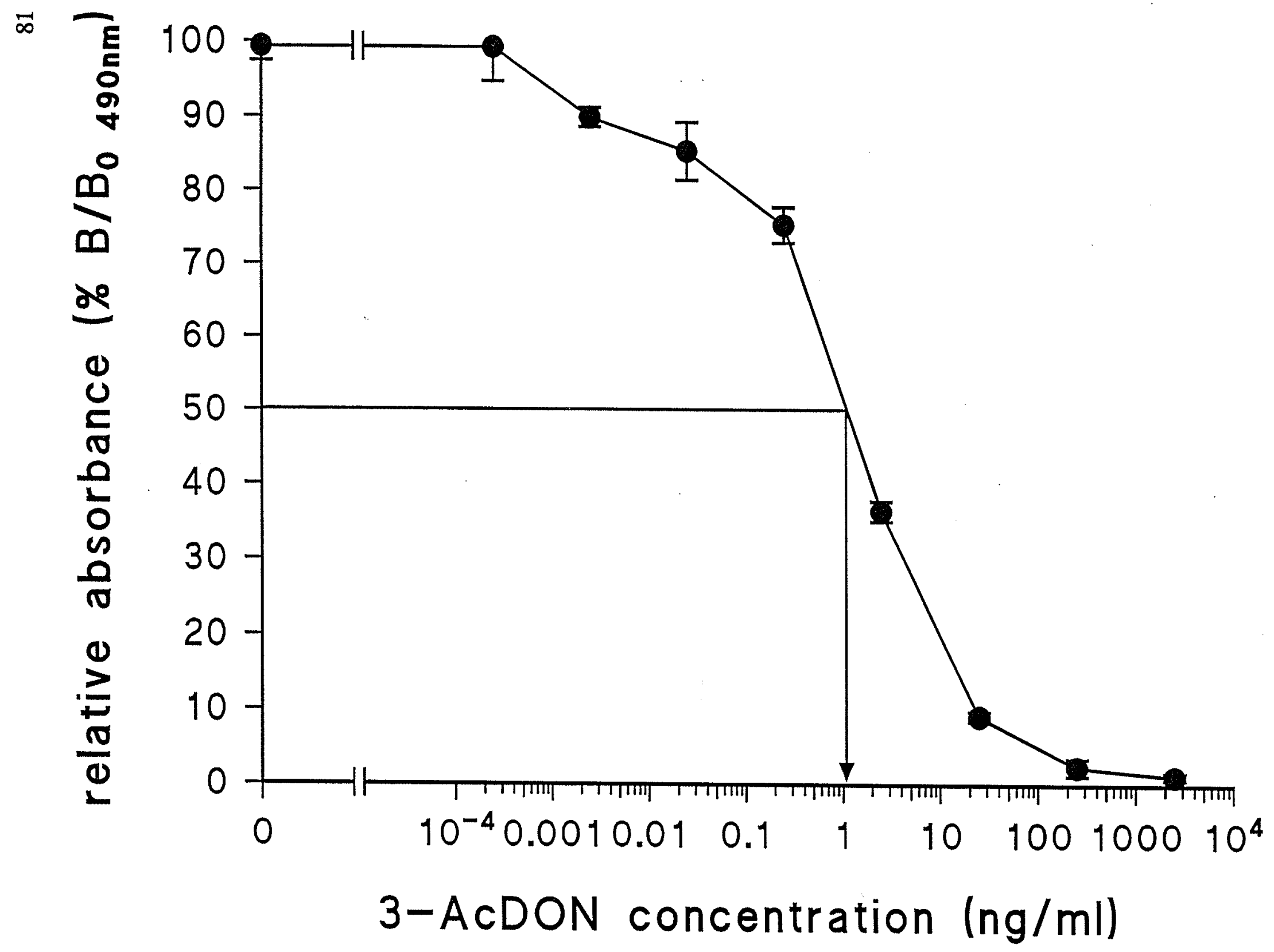




\section{DISCUSSION}

Mycotoxins are low-molecular weight compounds and, like other haptens, must be chemically coupled to a protein carrier to elicit an antibody response in host animals (Chu, 1991a). In the present study, the immunogen was produced by linking the C-15 hydroxyl group of 3-AcDON to HSA through a hemisuccinate ester bridge (Kitagawa et al, 1981 and Usleber et al, 1991). The characteristics of the derivative as determined by TLC were in agreement with those reported previously (Usleber et al, 1991) and indicated that the derivative was a single compound, 3-AcDON-HS. Usleber et al (1991) demonstrated on the basis of ${ }^{1} \mathrm{H}$ NMR, that only the C-15 hydroxyl group was derivatized. Several other studies have also shown that the C-15 hydroxyl group of 3AcDON or DON is highly reactive, whereas the C-7 hydroxyl group is less reactive due to its secondary character and the formation of a hydrogen bond with the C-8 ketone group (Greenhalgh et al, 1984; Mills et al, 1990; Savard, 1991 and Sinha et al, 1995).

The use of 3-AcDON-HG-OVA (a conjugate with a homologous linkage and a heterologous carrier protein) as the coating conjugate in the indirect competitive antibody capture ELISA yielded high background values as free 3-AcDON was not able to effectively inhibit the reaction between the conjugate and the antiserum. The uninhibitable reaction was probably caused by the interaction of a subpopulation of antibodies with the ester bridge (Wei and Hammock, 1984). The recognition of a chemical bridge by anti-hapten antibodies has been referred to as "bridge binding" which 
was originally observed in the steroid immunoassay (Nordblom et al, 1981) and subsequently noted by other researchers (Goodrow et al, 1990; Kierek-Jaszczuk et al, 1995; Sheth and Sporns, 1991; Vallejo et al, 1982; Wei and Hammock, 1984). Previously developed immunoassays for DON and 3-AcDON have also utilized antibodies elicited by immunogens where toxins and proteins were linked via a hemisuccinate ester bridge and the competitive inhibition was achieved by the use of a plate coating conjugate that had a hemiglutarate instead of hemisuccinate bridge (Kemp et al, 1986 and Usleber et al, 1991). This approach did not, however, solve the problem in the current research as a high background with a very low degree of inhibition still occurred when a conjugate of this type was used for plate coating. This suggested that the binding of the bridge determinants by this antibody could not be reduced simply by altering the length of the bridge. Therefore, to eliminate the binding of antibody to the linking portion of the conjugate, alternative chemistries including carboxymethylation of $\mathrm{C}-15$ hydroxyl group and the oximation of the C-8 carbonyl group were used to produce coating antigens with different bridging structures and/or sites of attachment. It was assumed, as suggested for the esterification reaction, that the hydroxyl group at the $\mathrm{C}-15$ position was the primary substrate in the carboxymethylation reaction (Greenhalgh et al, 1984 and Savard, 1991). Assays using these conjugates yielded inhibition curves with much greater sensitivities and much lower background values (3\% maximum absorbance) compared to that obtained by the use of the coating antigen containing the hemiglutarate bridge (Figure 8). The assay with the oxime bridge conjugate, however, was impractical as it required more than $6 \mathrm{hr}$ to develop suitable absorbance value. This low rate of 
reaction may be attributed to the lack of recognition of the C-8 site of 3-AcDON as the C-8 carbonyl group at this site was modified in 3-AcDON-CMO-OVA (D4). The C-8 site, however, was left intact in the conjugates containing either the hemisuccinate (B1) hemiglutarate (B2) or the methylcarboxyl bridge (B3, Figure 13), therefore, antibodies raised against the immunogen prepared from B1 (3-AcDON-HS) more readily recognized the conjugates derived from $\mathrm{B} 2$ (3-AcDON-HG) or B3 (3-AcDON-MC) than that from B4 (3-AcDON-CMO).

The observation that the antibody had a much higher ( 9 fold) reactivity toward acetylated DON than 3-AcDON (Table 6) suggests that the assay also would be suitable for the monitoring of the entire group of DON toxins. This could be achieved by converting DON, and all its acetylated analogs, to the acetylated form of DON using the acetylation procedure described in Materials and Method. The acetylated products of DON and NIV were monitored by TLC and were presumed as triacetylated analoges. Anti-DON antibodies produced by other researchers have also exhibited a high crossreactivity towards acetylated DON derivatives and have been used for the detection of the DON-type mycotoxins (Xu et al, 1988 and Zhang et al, 1986).

Barley was used as the agricultural matrix in the study as it is a major agricultural crop and a common substrate of the Fusarium contamination. The hull part of the grain makes it difficult to visually differentiate between the infected and uninfected barley, therefore the reliable screening for toxins in this grain is of a particular importance. The result of spiked barley experiment shows that the assay can be used to quantitatively monitor the presence of $3-A c D O N$ in grain at a concentration as low as $16 \mathrm{ppb}$. 
Figure 13. Three-dimensional molecular computer images of 3-AcDON derivatives used in the preparation of the immunogen and the coating antigens. 3-AcDON-HS (B1); 3-AcDON-MC (B3) and 3-ACDON-OXM (B4). 
$\infty$

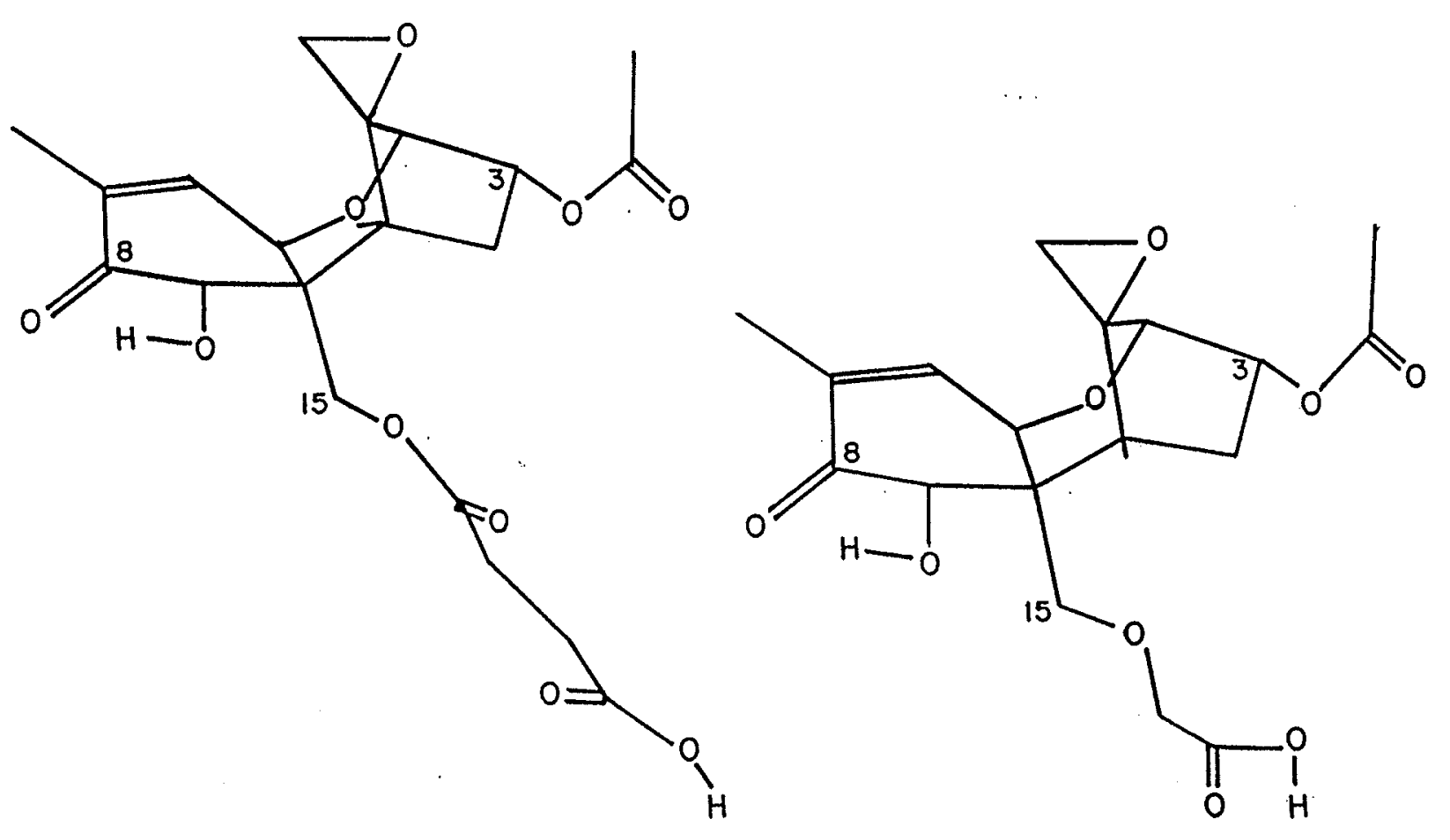

BI

B3

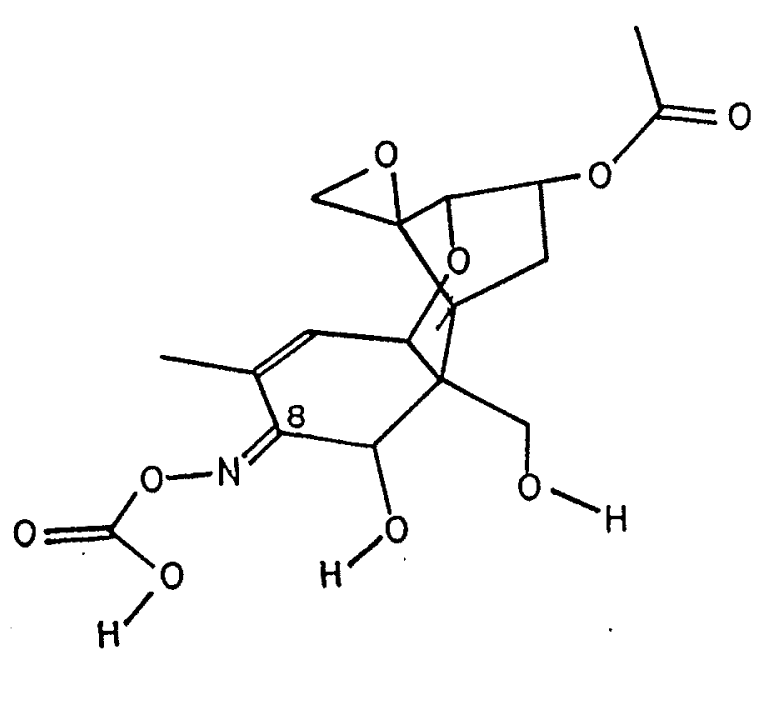

B4 
The direct competitive ELISA was developed using 3-AcDON-HRP, which is a heterologous assay antigen compared to the immunogen. The assay was 5 times less sensitive than the indirect format, however, the direct format is desirable in most commercial available kit as it requires one less step than the indirect format. In the direct assay, incubation with a second antibody-enzyme conjugate not required. The reduction in sensitivity of the direct test is also not a problem as the detection limits of the direct assay would will be in the range of $0.1 \mathrm{ppm}(16 \mathrm{ppb} \times 5$, theoretically). This is considerably below the limit deemed to be safe (Scott, 1990). 


\section{SUMMARY}

In summary, rabbit polyclonal antibodies were produced against 3-AcDON by hemisuccinate derivatization of the $\mathrm{C}-15$ hydroxyl group. The ester linkage (hemisuccinate bridge) containing conjugate was shown to be adequate for antibody production but was not suitable as a coating antigen in the current study even when a different length linkage (hemiglutarate) was used. Two other chemistries were used to produce 3-AcDON-protein carrier conjugates containing different bridging groups for the coating antigen in developing the indirect antibody capture ELISA. The use of a heterologous coating conjugate that contained an $O$-methylcarboxyl bridge significantly increased the sensitivity of the ELISA and reduced the non-inhibitable background to a nearly zero relative absorbance value. 3-AcDON using this assay was readily quantitated in barley with the detection limit being $16 \mathrm{ppb}$. A direct ELISA format also yielded promising results. The following additional research is recommended: 1) the optimization of the direct ELISA and the use of this assay to detect toxin in grain samples; 2) further investigations into the use of chicken $\operatorname{Ig} Y$ in the assay and 3) use of the developed assay to detect DON and its analogs following the acetylation of grain extracts. This latter modification would permit the detect of not only 3-AcDON but also all DON-type toxins. 


\section{LITERATURE CITED}

Abouzied, M.M., J.I. Azcona, W.E. Braselton, and J.J. Pestka. 1991a. Immunochemical assessment of mycotoxins in 1989 grain foods: Evidence for deoxynivalenol (vomitoxin) contamination. Appl. Envir. Micro. 57:672-677.

Abouzied, M.M., M.N. Beremand, S.P. McCormick and J.J. Pestka. 1991b. Reactivity of deoxynivalenol (vomitoxin) monoclonal antibody towards putative trichothecene precursors and shunt metabolites. J. Food Prot. 54:288-290.

ApSmimon, J.W., B.A. Blackwell, L.Blais, D.A. Fielder, R. Greenhalgh, G. Kasitu, J.D. Miller and M. Savard. 1990. Mycotoxins from Fusarium species, detection, determination and variety. Pure \& Appl. Chem. 62:1339-1346.

Atkinson, H.A.C. and K. Miller. 1984. Inhibitory effect of deoxynivalenol, 3acetyldeoxynivalenol and zearalenone on induction of rat and human lymphocyte proliferation. Toxicol. Lett. 23:215-221.

Barna-Vetró, I., Á. Gyöngyösi and L. Solti. 1994. Monoclonal antibody-based enzyme-linked immunosorbent assay of Fusarium T-2 and zearalenone toxins in cereals. Appl. Envir. Micro. 60:729-731.

Baxter, J.A., S.J. Terhune and S.A. Qureshi. 1983. Use of chromotropic acid for improved thin-layer chromatographic visualization of trichothecene mycotoxins.

J. Chromo. 26:130-133. 
Bayard, F., I.Z. Beitins, A. Kowarski and C.J. Migeon. 1970. Measurement of plasma aldosterone by radioimmunoassay. J. Clin. Endocrinol. Metabol. 31:1-6.

Bennett, G.A. and O.L. Shotwell. 1990. Criteria for determining purity of Fusarium mycotoxin. J. Assoc. Off. Anal. Chem. 73:270-275.

Betina, V. 1989. Trichothecenes. In: Y. Ueno (Ed.) Mycotoxins, Chemical, Biological and Environmental Aspects. Elsevier Science Publishing Company Inc. New York.

Booth, C. 1971. The species of Fusarium. In: The Genus Fusarium, Commonwealth Mycological Institute. Kew, Sunny, England.

Bradford, M.M. 1976. A rapid and sensitive method for the quantitation of microgram quantities of protein utilizing the principles of protein-dye binding. Anal. Biochem. 72:248-254.

Candlish, A.A.G. 1991. Determination of mycotoxins in animal feeds by biological methods. In: J.E. Smith and R.S. Henderson (Ed.) Mycotoxins and Animal Foods. CRC Press Inc. Boca Reca, Florida.

Casale, W.L., J.J. Pastka and L.P. Hart. 1988. Enzyme linked immunosorbent assay employing monoclonal antibody specific for deoxynivalenol (vomitoxin) and several analogues. J. Agric. Food Chem. 36:663-668.

CAST. 1989. Mycotoxins, economic and health risks. Council of Agricultural Science and Technology (CAST), Task force report. No.116, CAST, AMES, IA.

Chu, F.S. 1991a. Current immunochemical methods for mycotoxin analysis. In: M. Vanderlaan, L.H. Stanker, B.E. Watkins and D.W. Roberts (Ed.) Immunoassays 
for Trace Chemical Analysis: Monitoring Toxic Chemicals in Humans, Foods and the Environment. ACS Symp. Ser. 451:140-157.

Chu, F.C. 1991b. Development and use of immunoassays in detection of ecologically important mycotoxins. In: D. Bhatnager, E.B. Lillihoj and D.K. Arora (Ed.) Handbook of Applied Mycology. Vol. V. Mycotoxins. Marcel Dekker, New York.

Clarke, J.R., R.R. Marquardt, A. Oosterveld, A.A. Frohlich, F.J. Madrid and M. Dawwood. 1993. Development of quantitative and sensitive enzyme-linked immunosorbent assay for ochratoxin A using antibodies from yolk of laying-hen. J. Agric. Food Chem. 41:1784-1789.

Clear, R.M. and D. Abramson. 1986. Occurrence of fusarium head blight and deoxynivalenol (vomitoxin) in two samples of Manitoba wheat in 1984. Can. Plant Dis. Surv. 66:9-11.

Colburn, W.A. 1975. Radioimmunoassay for fluoxymesterone (halotestin). Steroids $25: 42-52$.

Desjardins, A.E., G.F. Speneer, R.D. Plattner and M.W. Beremand. 1989. Furanocoumarin Phytoalexins, trichothecenes and infection of Pastinaca sativa by Fusarium Sporotrichioides. Phytopatholo. 79:170-75.

Diekman, M.A. and M.L. Green. 1992. Mycotoxins and reproduction in domestic livestock. J. Anim. Sci. 70:1615-1627.

Engvall, E. and P. Perlman. 1971. Enzyme-linked immunosorbent assay (ELISA) quantitative assay of immunoglobulin G. Immunochemistry. 8:871-874. 
Erlanger, B.F., F. Borek, S.M. Beiser and S. Lieberman. 1959. Steroid-protein conjugate. J. Biol. Chem. 234:1090-1094.

Forsell, J.H., R. Jensen, J.H. Tai, M. Witt, W.S. Lin and J.J. Pestka. 1987. Comparison of toxicities of deoxynivalenol (vomitoxin) and 15acetyldeoxynivalenol in the B6C3F1 mouse. Food Chem. Toxic. 25:155-162.

Foster, B.C., H.L. Trenholm, J.I. Elliot, B.K. Thompson and K.E. Hartin. 1986. Evaluation of different sources of deoxynivalenol (vomitoxin) fed to swine. Can. J. Anim. Sci. 66:1149-1153.

Godtfredsen, W.O., J.F. Grove and C. Tamm. 1967. Verrucarins and roridins XV, normen clature of a new class of sesquiterpenes. Helv. Chim. Acta 50:1666-

Goodrow, M.H., R.O. Harrison and B.D. Hammock. 1990. Hapten synthesis, antibody development and competitive inhibition enzyme immunoassay for $s$ triazine herbicides. J. Agric. Food Chem. 38:990-996.

Greenhalgh, R., G.A. Neish and J.D. Miller. 1983. Deoxynivalenol, acetyldeoxynivalenol and zearalenone formation by Canadian isolates of Fusarium graminearum on solid substrate. Appl. Environ. Microbiol. 46:625-629.

Greenhalgh, R., A.W. Hanson, J.D. Miller and A. Taylor. 1984. Production and Xray crystal structure of $3 \alpha$-acetoxy-7 $\alpha, 15$-dihydroxy-12,13-epoxytrichothec-9-en8-one. J. Agric. Food Chem. 32:945-948.

Harlow, E. and D. Lane. 1988. Protocols for immunoassays. Chapter 14. In: Antibodies, a Laboratory Manual. Cold Spring Harbor Laboratory, New York. Harvey, R.B., L.F. Kubena, D.E. Corrier, D.A. Witzel, T.D. Phillips and N.D. 
Heidelbaugh. 1986. Effect of deoxynivalenol in a wheat ration fed to growing lambs. Am. J. Vet. Res. 47:1630-1632.

Howanitz, P.J. 1988. Immunoassay development and direction in antibody technology. Arch. Pathol. Lab. Med. 112:771-774.

Huff, W.E., J.A. Doerr, P.B. Hamilton and R.F. Vesonder. 1981. Acute toxicity of vomitoxin (deoxynivalenol) in broiler chickens. Poul. Sci. 60:1412-1414.

Inman, J.K. 1975. Thymus-independent antigens: the preparation of covalent haptenficoll conjugates. J. Immunol. 114:704-709.

Kamimura, H., M. Nishijima, K. yasuda, K. Saito, A. Ibe, T. Nagayama, H. Ushiyama and Y. Naoi. 1981. Simultaneous detection of several Fusarium mycotoxins in cereals, grains and foodstuffs. J. Assoc. Off. Anal. Chem. 64:1067-1073.

Kasali, O.B., H.B. Schiefer, D.S. Hancock, B.R. Blakley and R.S. Tomar. 1985. Subacute toxicity of dietary 3-acetyldeoxynivalenol in mice. Can. J. Comp. Med. 49:319-322.

Kemp, H.A., E.N.C. Mills and M.R.A. Morgan. 1986. Enzyme-linked immunosorbent assay of 3-acetyldeoxynivalenol applied to rice. J. Sci. Food Agric. 37:888-894.

Kierek-Jaszczuk, D., R.R. Marquardt, A. Frohlich, J. Clarke, H. Xiao and D. Abramson. 1995. Detection and quantitation of the T-2 mycotoxin by ELISA utilizing toxin specific polyclonal antibodies raised in chickens. J. Agric. Immunol. 7:2432-252. 
Kitagawa, T., T. Shimozono, T. Aikawa, T. Yoshida and H. Nishimura. 1981. Preparation and characterization of hetero-bifunctional crosslinking reagents for protein modifications. Chem. Pharm. Bull. 29:1130-1135.

Lauren, D.R. and R. Greenhalgh. 1987. Simultaneous analysis of nivalenol and deoxynivalenol in cereals by liquid chromatography. J. Assoc. Off. Anal. Chem. 70:479:483.

Luo, Y., T. Yoshizawa and T. Katayama. 1990. Comparative study on the natural occurrence of Fusarium mycotoxins in corn and wheat from high and low-risk areas for human esophageal cancer in China. Appli. Envir. Micro. 56:37233726.

Miller, J.D., A. Taylor and R. Greenhalgh. 1983. Production of deoxynivalenol and related compound in liquid culture by Fusarium graminearum. Can. J. Microbiol. 29:1171-1178.

Mills, E.N.C., S.M. Alcock, H.A. Lee and M.R.A. Morgan. 1990. An enzymelinked immunosorbent assay for deoxynivalenol in wheat, utilizing novel hapten derivatization procedures. Food Agric. Immunol. 2:109-118.

Moss, M.O. 1991. The environmental factors controlling mycotoxin formation. In: J.E. Smith and R.S. Henderson (Ed.) Mycotoxins and Animal Foods. CRC Press Inc., Ann Arbor.

Nicol, M.J., D.R. Lauren, C.O. Miles and W.T. Jones. 1993. Production of a monoclonal antibody with specificity for deoxynivalenol, 3-acetyldeoxynivalenol and 15-acetyldeoxynivalenol. Food and Agric. Immuno. 5:199-209. 
Noller, C.H., M.Stob, J. Tuite. 1979. Effect of feeding Gibberella zeae -infected corn on feed intake, body weight gain and milk production of dairy cows. J. Dairy. Sci. $62: 1003-1006$.

Nordblom, G.D., R. Webb, R.E. Counsell and B.G. England. 1981. A chemical approach to solving bridging phenomena in steroid radioimmunoassays. Steroids 38:161-173.

Pestka, J.J. 1988. Enhanced surveillance of foodborne mycotoxins by immunochemical assay. J. Assoc. Off. Anal. Chem. 71:1075-1081.

Prelusky, D.B., H.L. Trenholm, R.M. Hamilton and J.D. Miller. 1987. Transfer of $\left[{ }^{14} \mathrm{C}\right]$ deoxynivalenol to eggs following oral administration to laying hens. $J$. Agric. food Chem. 35:182-186.

Price, W.D., R.A. Lovell and D.G. McChesney. 1993. Naturally occurring toxins in feedstuffs: center for veterinary medicine perspective. J. Anim. Sci. 71:25562562.

Putnam, M.L and K.A. Binkerd. 1992. Comparison of a commercial ELISA kit and TLC for detection of deoxynivalenol in wheat. Plant Dis. 76:1078-1079.

Richard, J.L., G.A. Bennett, P.F. Ross and P.E. Nelson. 1993. Analysis of naturally occurring mycotoxins in feedstuffs and food. J. Anim. Sci. 71:2563-2574.

Rodbard, D. and S.W. McClean. 1977. Automated computer analysis for enzymemultiple immunological techniques. Clin. Chem. 23:112-115.

Savard, M.C. 1991. Deoxynivalenol fatty acid and glucoside conjugates. J. Agric. Food Chem. 39:570-574. 
Schiefer. H.B., S. Nicholson, O.B. Kasali, D.S. Hancock and R. Greenhalgh. 1985. Pathology of acute 3-acetyldeoxynivalenol toxicity in mice. Can. J. Comp. Med. $49: 315-318$

Scott, P.M. 1982. Assessment of quantitative methods for determination of trichothecenes in grains and grain products. J. Assoc. Off. Anal. Chem. 65:867883.

Scott, P.M. 1983. Trichothecene problems in Canada. In: Y. Ueno (Ed.) Trichothecenes---Chemical, Biological and Toxicology Aspects. Elsevier, New York.

Scott, P.M. 1990. Trichothecenes in grains. Cereal Food World 35:661-665.

Scott, P.M. 1993. Fumonisins. Int. J. Food Microbiol. 18:257-270.

Sheth, H.B. and P. Sporns. 1991. Development of a single ELISA for detection of sulfonamides. J. Agric. Food Chem. 39:1696-1700.

Sinha, R.C., M.E. Savard and R. Lau. 1995. Production of monoclonal antibodies for the specific detection of deoxynivalenol 15-acetyldeoxynivalenol by ELISA. J. Agric. Food Chem. 43:1740-1744.

Smith, T.K. 1990. The use of trichothecene contaminated grains in feeds. Can. J. Physiol. Pharmacol. 68:1000-1003.

Snijiders, C.H.A. 1994. Breeding for resistance to Fusarium in wheat and maize. In: J.D. Miller and H.L. Trenholm (Ed.) Mycotoxin in Grain, Compounds Other Than Aflatoxin. Eagan Press. Minnesota.

Staab, H.A. 1962. Syntheses using heterocyclic amides (azolides). Angew. Chem. 
Internat. Edit. 1:351-367.

Steyn, P.S., P.G. Theil and D.W. Trinder. 1991. Detection and quantification of mycotoxins by chemical analysis. In: J.E. Smith and R.S. Henderson (Ed.) Mycotoxins and Animal Foods. CRC Press Inc. Boca Raton, Florida.

Takitani, S and Y. Asabe. 1983. Thin-layer chromatographic analysis of trichothecene mycotoxins. In: Y.Ueno (Ed.) Trichothecenes---Chemical, Biological, and Toxicology Aspects. Elsevier, New York.

Tanaka, T., A. Hasegawa, Y. Matsuki, K. Ishii and Y. Ueno. 1985. Improved methodology for the simultaneous detection of trichothecene mycotoxins deoxynivalenol and nivalenol in cereals. Food Add. Contam. 2:125-129.

Tanaka, T., A. Hasegawa, S. Yamamoto, U.S. Lee, Y. Sugiura and Y. Ueno. 1988. Worldwide contamination of cereals by the fusarium mycotoxins nivalenol, deoxynivalenol and zearalenone. 1. survey of 19 countries. J. Agric. Food Chem. 36:979-983.

Teich, A.H. and J.R. Hamilton. 1985. Effect of cultural practices, soil phosphorus and deoxynivalenol levels in wheat. Appl. Envir. Micro. 49:1429-1431.

Tomar, R.S., B.R. Balkey and W.E. Deccoteau. 1987. Immunological responsiveness of mouse spleen cells after in vivo or in vitro exposure to 3-acetyldeoxynivalenol. Food. Chem. Toxicol. 25:393-398.

Trenholm, H.L., R.M.G. Hamilton, D.W. Friend and B.K. Thompson. 1984. Feeding trails with vomitoxin (deoxynivalenol)-contaminated wheat: effect on swine, poultry and dairy cattle. J. Vet. Med. Assoc. 85:527-531. 
Trenholm, H.L., B.K. Thompson, K.E. Hartin, R. Greenhalgh and A.J. McAuiseter. 1985. Ingestion of vomitoxin (deoxynivalenol)-contaminated wheat by nonlactating dairy cows. J. Dairy. Asc. 68:1000-1005.

Trenholm, H.L., L.L. Charmley, D.B. Prelusky and R.M. Waner. 1991. Two physical methods for the detoxification of four cereals contaminated with deoxynivalenol and zearalenone. J. Agric. Food. Chem. 39:356-360.

Trenholm, H.L., L.L. Charmley, D.B. Prelusky and R.M. Waner. 1992. Washing procedures using water or sodium carbonate solutions for the decontamination of three cereals contaminated with deoxynivalenol and zearalenone. J. Agric. Food. Chem. 40: 2147-2151.

Trenholm, H.L., B.C. Foster, L.L. Charmley, B.K. Thompson K.E. Hartin, R.W. Coppock and M.A. Albassam. 1994. Effect of feeding diets containing Fusarium (naturally) contaminated wheat or pure deoxynivalenol in growing pigs. Can. J. Anim. Sci. 74:361-369.

Trucksess, M.W., S. Nesheim and R.M. Eppley. 1984. Thin-layer chromatographic determination of deoxynivalenol in wheat and corn. J. Assoc. Off. Anal. Chem. $67: 40-42$.

Trucksess, M.W., M.T. Flood, M.M. Mossoba and S.W. Page. 1987. Highperformance thin layer chromatographic determination of deoxynivalenol, fusarenon-X and nivalenol in barley, corn and wheat. J. Agric. Food Chem. $35: 445-448$.

Truckess, M.W., D.B. Bark, C. Milan, et al. 1994. In: AOAC International Joint 
Mycotoxin Committee Meeting. Portland, Oregon.

Uneo, Y. 1983. Trichothecenes: Chemical, Biological and Toxicological Aspect (Development in Food Science 4). Elsevier Science Publishing Company Inc. Amsterdam.

Ueno, Y. 1984. The toxicology of mycotoxins. CRC Crit. Revs. Toxicol. 14:99-132.

Usleber, E., E. Märtlbauer, R. Dietrich and G. Terplan. 1991. Direct enzyme linked immunosorbent assays for detection of the 8-ketotrichothecene mycotoxins deoxynivalenol, 3-acetyldeoxynivalenol and 15-acetyldeoxynivalenol in buffer solutions. Agric. Food Chem. 39:2091-2095.

Usleber, E., E. Schneider, E. Märtlbauer and G. Terplan. 1993. Two formats of enzyme immunoassay for 15-acetyldeoxynivalenol. Agric. Food Chem. 41:20192023.

Vallejo, R.P., E.R. Bogus and R.O. Mumma. 1982. Effects of hapten structure and bridging groups on antisera specificity in parathion immunoassay development. J. Agric. Food Chem. 30:572-580.

Vesonder, R.F., A. Ciegler and A.H. Jenson. 1973. Isolation of principle from Fusarium infected corn. Appl. Microbiol. 26:1008-1010.

Waston, D.H. 1985. In: Toxic fungal metabolites in foods. Volume 22. Issue 3. pp. Wëi, S.I. and B.D. Hammock. 1984. Comparison of coating and immunizing antigen structure on the sensitivity and specificity of immunoassays for benzyolphenylurea insecticides. J. Agric. Food Chem. 32:1294-1301.

West, D.I. and L.B. Bullerman. 1991. Physical and chemical separation of mycotoxins 
from agricultural products. In: J.E. Smith and R.S. Henderson (Ed.) Mycotoxins and Animal Foods. CRC Press Inc. London.

Xiao, H., J.R. Clarke, R.R. Marquardt and A.A. Frohlich. 1995. Improved methods for conjugating selected mycotoxins to carrier protein and dextran for immunoassays. J. Agric. Food. Chem. 43:2092-2097.

Xu, Y.C., C.S. Zhang and F.S. Chu. 1986. Radioimmunoassay of deoxynivalenol in wheat and corn. J. Assoc. Off. Anal. Chem. 69:967-969.

Xu, Y.C., G.S. Zhang and F.S. Chu. 1988. Enzyme linked immunosorbent assay for deoxynivalenol in corn and wheat. J. Assoc. Off. Anal. Chem. 71:945-949.

Yalow, R.S. and S.A. Berson. 1959. Assay of plasma insulin in human subjects by immunological methods. Nature. 184:1648-1649.

Yoshizawa, T. and N. Morooka. 1973. Deoxynivalenol and its monoacetate: new mycotoxins from Fusarium roseum and moldy barley. Agric. Biol. Chem. 37:2933-2934.

Yoshizawa, T. and N. Morooka. 1975. Biological modification of trichothecene mycotoxins: acetylation and deacetylation of deoxynivalenol by Fusarium spp. Appl. Microbiol. 29:54-58.

Yoshizawa, T. and N. Morooka. 1977. In: J.V. Rodricks, C.W. Hesseltine and M.A. Mehlman (Ed.) Mycotoxins in Human and Animal Health. Chem-Orbital, Park Forest South, Illinois.

Young, A.B., N.D. Davis and U.L. Diener. 1980. The effect of temperature and moisture on tennazonic acid production by Alternaria tenuissima. Phytopatholo. 
70:607-610.

Zhang, G.S., S.W. Li and F.S. Chu. 1986. Production and characterization of antibody against deoxynivalenol triacetate. J. Food. Prot. 49:336-339. 